\title{
Molekulargenetische Analysen fortpflanzungsrelevanter Fragestellungen beim landwirtschaftlichen Nutztier
}

\author{
Dissertation \\ zur Erlangung des Doktorgrades \\ der Fakultät für Agrarwissenschaften \\ der Georg-August-Universität Göttingen
}

\author{
vorgelegt von \\ Isabel Wiedemann \\ geboren in Holzminden
}


D 7

1. Referent: Prof. Dr. Jens Tetens

2. Korreferent: Prof. Dr. Dr. Matthias Gauly Tag der mündlichen Prüfung: 09.11.2018 
Nicht am Ziel wird der Mensch groß, sondern auf dem Weg dorthin.

Ralph Waldo Emerson 



\section{Veröffentlichungen}

Diese Arbeit basiert auf folgenden Veröffentlichungen:

\section{Beiträge in referierten Fachzeitschriften}

Jansen, S., Sharifi, A. R., Knorr, C., Wiedemann, I. (2017):

Analyse von morphologisch veränderten Spermien in Ejakulaten von Besamungsebern. Züchtungskunde 89(4), 300-310

Wiedemann, I., Mählmeyer, A., Jansen, S., Sharifi, A. R., Knorr C. (2018):

SNP g.1007A>G within the porcine DNAL4 gene affects sperm motility traits and percentage of midpiece abnormalities. Reproduction in Domestic Animals, 53(2): 401-413

Wiedemann, I., Krebs, T., Momberg, N., Knorr, C., Tetens, J. (2018):

mRNA expression profiling in cotyledons reveals significant up-regulation of the two bovine pregnancy-associated glycoprotein genes boPAG-8 and boPAG-11 in early gestation. Veterinary Medicine and Science, 4(4): 441-450

\section{Kongressbeiträge}

Wiedemann, I., Mählmeyer, A., Sharifi, A. R., Knorr, C. (2014):

Assoziationen zwischen Varianten des porcinen DNAL4-Gens und spermatologischen Parametern (Vortrag D15). Vortragstagung der DGfZ/GfT, 17.-18.09.2014 in Dummerstorf

Wiedemann, I., Mählmeyer, A., Jansen, S., Sharifi, A. R., Knorr, C. (2016):

SNP g.1007A $>G$ within the porcine DNAL4 gene affects sperm motility and percentage of midpiece abnormalities (Poster 636). Plant and Animal Genome XXIV Conference, 09.-13.01.2016 in San Diego

Wiedemann, I., Krebs, T., Momberg, N., Tetens, J., Knorr, C. (2018):

Expressionsanalyse ausgewählter boviner PAG-Gene (Vortrag D18). Vortragstagung der DGfZ/GfT, 12.-13.09.2018 in Bonn 


\section{Inhaltsverzeichnis}

Veröffentlichungen ....................................................................................................... I

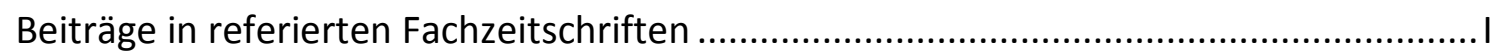

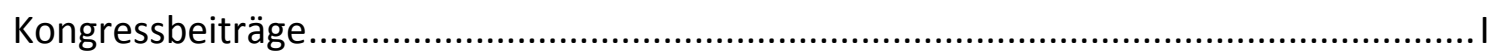

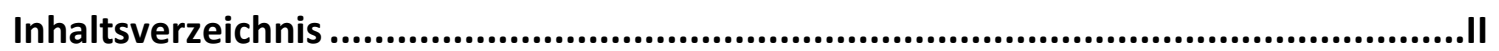

Abbildungsverzeichnis ............................................................................ IV

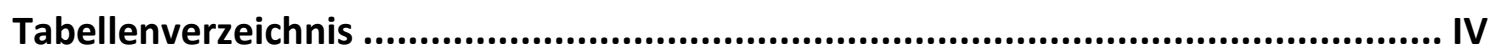

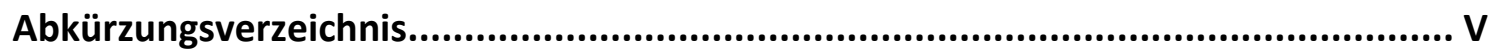

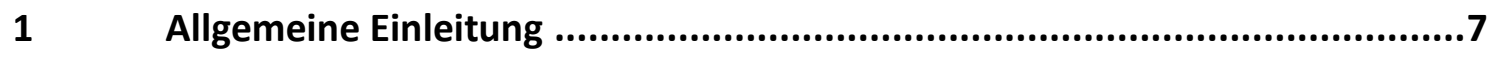

2 Einfluss von Umwelt und Genetik auf spermatologische Parameter .............9

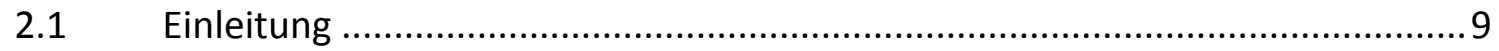

2.1.1 Morphologische Veränderungen in Ejakulaten von Besamungsebern ..............9

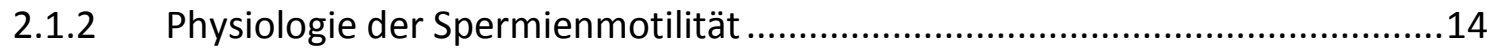

2.1.3 Genetischer Einfluss auf die Spermaqualität ...............................................16

2.2 Analyse von morphologisch veränderten Spermien in Ejakulaten von

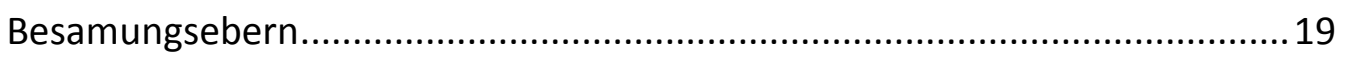

2.3 SNP g.1007A $>\mathrm{G}$ within the porcine DNAL4 gene affects sperm motility traits and percentage of midpiece abnormalities ................................................. 36

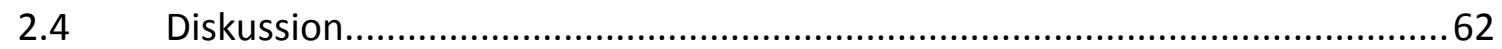

3 Expressionsanalyse ausgewählter boviner PAG-Gene (boPAG)...................68

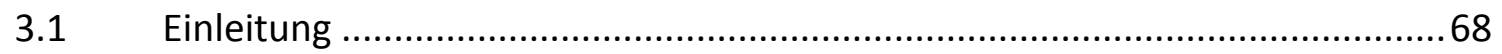

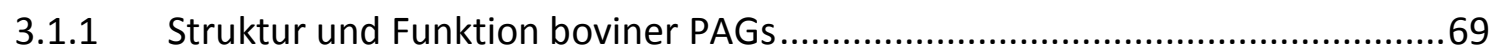

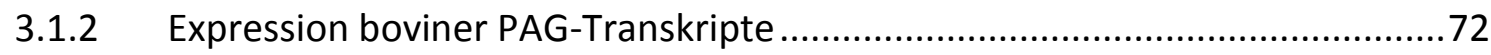

3.2 mRNA expression profiling in cotyledons reveals significant up-regulation of the two pregnancy-associated glycoprotein genes boPAG-8 and boPAG-11 in

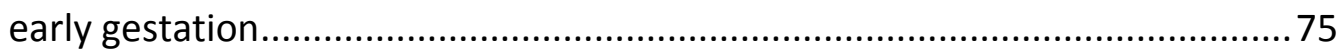




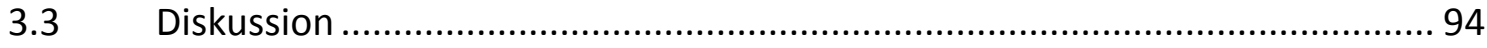

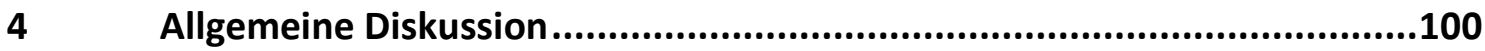

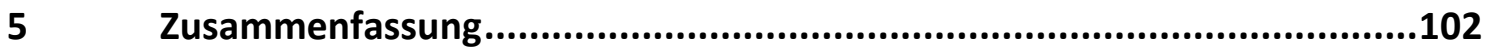

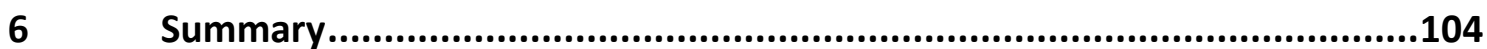

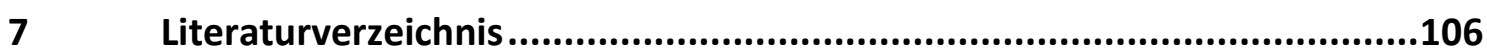

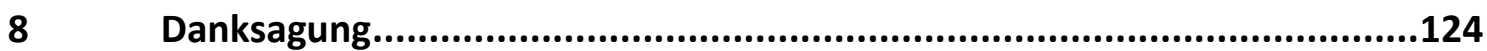

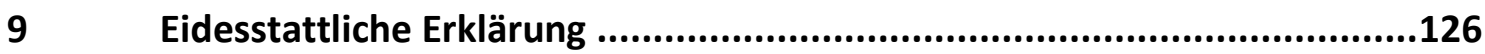




\section{Abbildungsverzeichnis}

Abbildung 2-1: Schematische Darstellung verschiedener Spermiendefekte

(modifiziert nach Weitze (2001)). 12

Abbildung 2-2: Schematische Darstellung des flagellären Axonems im Querschnitt

(modifiziert nach Lindemann \& Lesich (2010)). .15

Abbildung 2-3: Schematische Darstellung der Untereinheit des äußeren Dyneinarms

(modifiziert nach Mohri et al. (2012)).

Abbildung 3-1: Migration und Fusion binukleärer Zellen in der Wiederkäuer-

Plazenta (modifiziert nach Green et al., 1998b). 69

Abbildung 3-2: Expression boviner PAG-Gene im Verlauf der Trächtigkeit .73

Abbildung 3-3: Anlieferungszahlen von graviden Rindern am Schlachthof. .95

\section{Tabellenverzeichnis}

Tabelle 2-1: Anforderungen an Ejakulate von Besamungsebern hinsichtlich ihrer Eignung zum Einsatz in der KB (ZDS, 2005).

Tabelle 3-1: Überblick über das Vorkommen von PAG-Genen in verschiedenen Spezies. 


\section{Abkürzungsverzeichnis}

\begin{tabular}{|c|c|}
\hline AA & abnormal acrosome \\
\hline $\mathrm{AH}$ & abnormal head \\
\hline Al & artificial insemination \\
\hline AK & Altersklasse \\
\hline AM & abnormal midpiece \\
\hline AT & abnormal tail \\
\hline BHZP77 & Pietrain-Linie $\mathrm{db} .77^{\circledR}$ \\
\hline BNC & binucleated/binuclear cell \\
\hline boPAG & bovine pregnancy-associated glycoprotein \\
\hline$C D$ & cytoplasmic droplet \\
\hline CD9 & Tetraspanin-29 \\
\hline CONC & sperm concentration \\
\hline DE & Deutsches Edelschwein \\
\hline DL & Deutsche Landrasse \\
\hline DRM & dominant-recessive model \\
\hline DNAL4 & Dynein, axonemal light chain 4 \\
\hline ESR1 & Estrogen receptor-1 \\
\hline ESR2 & Estrogen receptor-2 \\
\hline for & forward-Primer \\
\hline GAPDH & Glycerinaldehyd-3-phosphat-Dehydrogenase \\
\hline GAPDS & Glycerinaldehyd-3-phosphat-Dehydrogenase-S \\
\hline GNRHR & Gonadotropin-releasing hormone receptor \\
\hline gZWS & genomische Zuchtwertschätzung \\
\hline$h^{2}$ & Heritabilität \\
\hline HD & high density \\
\hline IC & intermediate chain \\
\hline KB & Künstliche Besamung \\
\hline KF & Kopffehler \\
\hline KK & Kopfkappenfehler \\
\hline LC & light chain \\
\hline
\end{tabular}


LD linkage disequilibrium

LSmeans least square means

MOT1 Spermienmotilität nach 24-stündiger Lagerung

MOT2 Spermienmotilität nach 48-stündiger Lagerung

MOTUD Motilität von unverdünntem Sperma (direkt nach der Absamung)

MTFMT Mitochondrial methionyl-tRNA formyltransferase

$\mathrm{NCBI} \quad$ National Center for Biotechnology Information

OD optical density

ovPAG ovine pregnancy-associated glycoprotein

PAG pregnancy-associated glycoprotein

p. c. post coitum

PCR polymerase chain reaction

$\mathrm{PGE}_{2} \quad$ Prostaglandin $\mathrm{E}_{2}$

$\mathrm{Pi} / \mathrm{PI} \quad$ Pietrain

PSPB pregnancy-specific protein B

PT Plasmatropfen

qPCR real-time quantitative PCR

QTL quantitative trait locus/loci

rev reverse-Primer

S Jahreszeit/Saison der Ejakulatbildung

SF Schwanzfehler

SMR single marker regression analysis

SNP single nucleotide polymorphism

SSC porzines Chromosom

TierErzHaVerbG Tiererzeugnisse-Handels-Verbotsgesetz

VOL volume

ZDS Zentralverband der Deutschen Schweineproduktion e. V. 


\section{Allgemeine Einleitung}

Die Reproduktionsleistung landwirtschaftlicher Nutztiere hat massive Auswirkungen auf die Rentabilität der Betriebe, den Tierschutz und die Nachhaltigkeit der Tierproduktion (Beerda et al., 2008).

Die Eberfruchtbarkeit wird durch die Ejakulatqualität bestimmt. Diese kann durch verschiedene Faktoren, wie das Alter und die Rasse des Ebers, die Jahreszeit der Ejakulatgewinnung, sowie die Zeitspanne zwischen den Absamungen beeinflusst werden (Syring, 2008). Da diese Faktoren nicht immer steuerbar sind, wird eine genetische Verbesserung der Tiere immer wichtiger, um die Reproduktionsleistung zu gewährleisten und zu erhalten (Beerda et al., 2008). Bis heute wurden beim Schwein zahlreiche Untersuchungen zu weiblichen Reproduktionsmerkmalen veröffentlicht. Die Anzahl von Studien zur Eberfruchtbarkeit ist deutlich begrenzter, obwohl diese in der Schweineindustrie eine wichtigere Rolle einnimmt. Die männlichen Reproduktionsparameter sind komplexe, quantitative Merkmale, die durch eine Vielzahl von Genen mit jeweils sehr kleinen Effekten kontrolliert werden. Die Identifizierung von Polymorphismen in potentiellen Kandidatengenen ist dabei von Bedeutung für die markergestützte Selektion. Jedoch liegen nur wenige Informationen über Kandidatengene, die die Reproduktionsleistung von Ebern beeinflussen, vor (Liu et al., 2017).

Neben SNP- bzw. Kandidatengen-gestützten Analysen bietet die funktionelle Genomik neue Möglichkeiten für die moderne Tierzucht. Die Transkriptomik liefert Informationen, um die Auswirkungen der Selektion besser zu verstehen, indem sie für die Entschlüsselung der physiologischen Mechanismen, die den Fruchtbarkeitsmerkmalen zugrunde liegen, genutzt werden kann (Beerda et al., 2008). Die mRNA-Expression kann stellvertretend als Kenngröße für die phänotypische Variation dienen, wobei das Transkriptom einerseits genetisch determinierte differenzielle Merkmalsausprägungen widerspiegelt und sich andererseits Reaktionen auf verschiedene Umweltbedingungen als erstes im Transkriptom niederschlagen. Verschiedene Studien zeigten bereits, dass die Genexpression beim Rind während der Trächtigkeit eine Reihe von Prozessen, wie die maternale Trächtigkeitserkennung, Implantation, Embryogenese, Plazentation und Fetogenese, beeinflusst (Hashizume et al., 2007). 
Die vorgelegte Arbeit verfolgt zwei Ziele. Hauptziel des ersten Teils der Arbeit (Einfluss von Umwelt und Genetik auf spermatologische Parameter) war es, Assoziationen zwischen SNPs im porzinen DNAL4-Gen und spermatologischen Parametern aufzudecken, um diese als genetische Marker für die Eberfruchtbarkeit nutzen zu können. Das Ziel des zweiten Teils (Expressionsanalyse ausgewählter boviner PAG-Gene) war es, detaillierte mRNA-Expressionsprofile für ausgewählte moderne und anzestrale bovine trächtigkeitsassoziierte Glykoproteine (PAGs) mit einer hohen Dichte von Messzeitpunkten während der Trächtigkeit mittels real-time quantitativer PCR (qPCR) zu erzeugen. 


\section{Einfluss von Umwelt und Genetik auf spermatologische Parameter}

\subsection{Einleitung}

Die Nebenhodenreifung von Spermien führt, bezogen auf den Reifungsgrad und die Morphologie, physiologisch zu einer heterogenen Spermienpopulation. Die Morphologie der Spermien ist jedoch ein essentielles Kriterium für die Bewertung der Befruchtungsfähigkeit von Ejakulaten (Briz et al., 1995). Studien zeigten, dass die Spermienmotilität einer der wichtigsten Indikatoren für die Befruchtungsfähigkeit ist (Tardif et al., 1999) und daher sorgfältig evaluiert werden sollte (Haidl et al., 1991). Der Befruchtungserfolg ist eng mit der Anzahl motiler Spermien korreliert (Love, 2011), da eine Vorwärtsbeweglichkeit von unter $60 \%$ andere Fruchtbarkeitsparameter beeinflusst. Die Qualität eines Ejakulats wird durch verschiedene Faktoren beeinflusst. Dazu zählen das Alter und die Rasse des Ebers (u. a. Kennedy \& Wilkins, 1984; Kawecka et al., 2008) sowie die individuelle genetische Ausstattung, außerdem Haltungsbedingungen wie das Klima bzw. die Jahreszeit der Ejakulatgewinnung (Colenbrander et al., 1993; Suriyasomboon et al., 2005) sowie die Zeitspanne zwischen den Absamungen (Bonet et al., 1991; Pruneda et al., 2005).

\subsubsection{Morphologische Veränderungen in Ejakulaten von Besamungsebern}

Eine ausgereifte und befruchtungsfähige Spermienzelle besteht aus drei Komponenten: dem Spermienkopf, dem Halsstück und einer Geißel bzw. dem Spermienschwanz (Rovan, 2001). Ein wichtiger Bestandteil des Spermienkopfes ist das Akrosom, das aus dem Golgi-Apparat gebildet wird. Es befindet sich im Inneren des Kopfes und lediglich Konturen zeichnen sich als akrosomale Kappe (Kopfkappe) ab (Rovan, 2001). Morphologisch ist das Akrosom in drei Segmente, das Apikalsegment, das Hauptstück und das Äquatorialsegment untergliedert (Fawcett, 1975). Während der Spermiogenese werden Zellorganellen über Zytoplasmavesikel aus dem Kopfsegment ausgeschleust oder wie der Golgi-Apparat - umgebildet (Rovan, 2001). 
Dem Kopf schließt sich das Halsstück und somit der erste Teil des Spermienschwanzes an. Er wird weiter untergliedert in Mittel-, Haupt- und Endstück (Briz \& Fàbrega, 2013). Das Mittelstück besteht hauptsächlich aus dem zentral gelegenen Axonem (siehe Kapitel 2.1.2), das von den Mantelfasern und einer Mitochondrienhülle umgeben ist (Schülke, 1991; Briz \& Fàbrega, 2013). Die Mitochondrien umlaufen die Mantelfasern spiralförmig und dienen der Energieversorgung (Rovan, 2001). Durch den Anulus bzw. Jensen-Ring, einem aus Aktinfilamenten bestehenden Ring, wird das Mittelstück vom Hauptstück des Spermienschwanzes abgegrenzt. In diesem setzen sich die axonemalen Strukturen, umgeben von den Mantelfasern, fort. Allerdings werden diese anstelle von Mitochondrien von einer Proteinschicht umgeben (Rovan, 2001). Das Hauptstück geht dann in das Endstück des Flagellums, welches kein Cytoskelett mehr aufweist, über. Außerdem fehlen ihm die zentralen Mikrotubuli des Axonems, sodass die äußeren Dupletts des Axonems nur noch von der Plasmamembran umhüllt sind und sich in distal auslaufende Mikrotubuli aufspalten (Briz \& Fàbrega, 2013).

Männliche Individuen mit einer guten Fertilität weisen normalerweise einen hohen Prozentsatz normal entwickelter und uniformer Spermatozoen auf (Ombelet et al., 1995). Da jedoch nicht alle Spermatiden zu befruchtungsfähigen Spermatozoen heranreifen (Kaewmala et al., 2011), finden sich in Ejakulaten auch unreife oder morphologisch veränderte Spermien. Der Anteil reifer Spermien in einem durchschnittlichen Eberejakulat liegt zwischen 80 \% und 95 \%, das bedeutet der Anteil unreifer Spermien liegt zwischen $5 \%$ und $15 \%$ und der Anteil von veränderten bzw. missgebildeten Spermien zwischen 1 \% und 5 \% (Briz \& Fàbrega, 2013).

Missbildungen können dabei in allen Abschnitten des Spermiums auftreten, wie Abbildung 2-1 zeigt. Sie werden nach ihrer Lokalisation (Kopf, Halsmittelstück, Schwanz) und der möglichen Entstehungsursache (Blom, 1950) in primäre, sekundäre und tertiäre Veränderungen unterteilt. Primäre Defekte entstehen während der Spermatogenese im Hoden, sekundäre Effekte während der epididymalen Passage, Reifung und Lagerung und tertiäre Defekte durch äußere Einflüsse während bzw. nach der Ejakulation (Waberski \& Petrunkina, 2007; Menon et al., 2011). Zu den primären Veränderungen zählen Deformationen des Kopfes, respektive Akrosoms, ein para- bzw. retroaxialer Schwanzansatz, Missbildungen des Halsmittelstücks, sowie Doppel- und Mehrfach- 
missbildungen. Sekundäre Veränderungen beinhalten abgelöste Kopfkappen, Brüche im Bereich des Halsstücks, sowie Schwanzveränderungen wie beispielsweise Schleifen oder Aufrollungen und noch vorhandene Plasmatropfen. Zu den tertiären Veränderungen zählen abgelöste Kopfkappen, Schwanzschleifen und Halsbrüche. Sie sind von sekundären Missbildungen mikroskopisch kaum oder gar nicht zu differenzieren (Chenoweth, 2005; Waberski \& Petrunkina, 2007). Ursprünglich wurde angenommen, dass primäre Defekte durch direkte Verletzungen des Epithelium spermatogenicum verursacht werden. Dennoch ging man nicht davon aus, dass sie für die Fruchtbarkeit schädlicher sind als sekundäre Defekte, die durch eine Vielzahl von Ursachen, unter Umständen auch iatrogen, hervorgerufen werden können (Chenoweth, 2005). Daher klassifizierte Blom (1973) morphologische Veränderungen entsprechend ihres potentiellen Einflusses auf die Fertilität in Hauptdefekte und untergeordnete Defekte. Hauptdefekte umfassen die meisten Veränderungen des Kopfes, sowie des Mittelstücks und das Vorhandensein proximaler Plasmatropfen. Untergeordnete bzw. nebensächliche Defekte sind beispielsweise Schwanzschleifen, abgelöste Köpfe und distale Plasmatropfen (Chenoweth, 2005). 


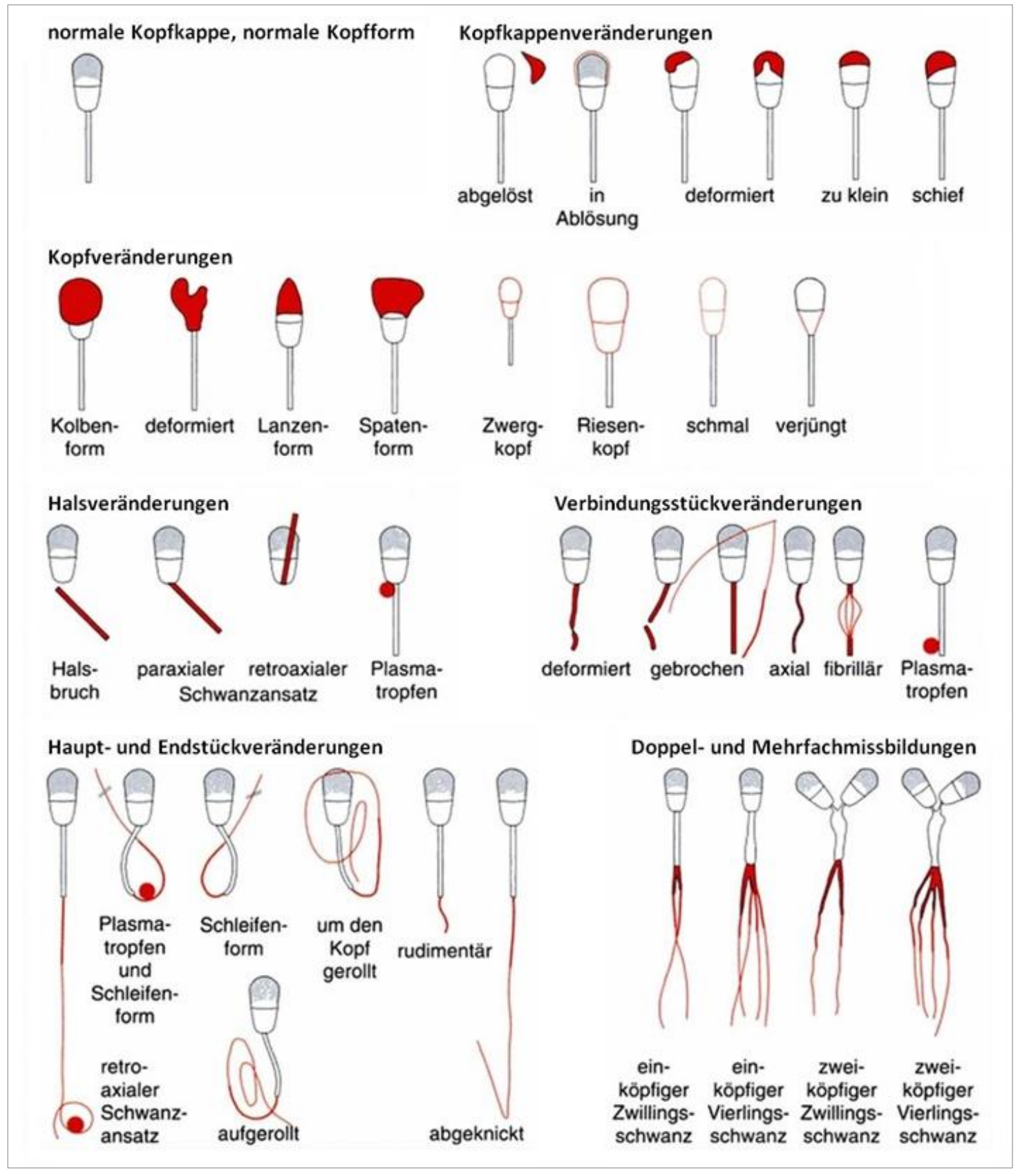

Abbildung 2-1: Schematische Darstellung verschiedener Spermiendefekte (modifiziert nach Weitze (2001)).

Der Zentralverband der Deutschen Schweineproduktion e. V. (ZDS) legte zur Sicherstellung der Spermaqualität und -quantität Richtwerte für die Ejakulate von Besamungsebern fest, um einen hohen Reproduktionserfolg bei der künstlichen Besamung zu gewährleisten (Tabelle 2-1). 
Tabelle 2-1: Anforderungen an Ejakulate von Besamungsebern hinsichtlich ihrer Eignung zum Einsatz in der KB (ZDS, 2005)

\begin{tabular}{ll}
\hline Merkmal & Mindestanforderung \\
\hline Farbe & grauweiß, weiß, gelbweiß \\
Konsistenz & molkig bis milchig \\
Beimengungen (Harn, Blut, Eiter) & keine \\
Verschmutzungen (Kotpartikel, Haare) & keine \\
Geruch & neutral \\
Volumen ohne Bulbourethraldrüsensekret (ml) & 100 \\
& Alter des Ebers: \\
Spermienkonzentration (Mio./ $\mu$ ) & $\leq 9$ Monate: 0,15 \\
& $>9$ Monate: 0,2* \\
& Alter des Ebers: \\
Spermiengesamtzahl (Mrd./Ejakulat) & $\leq 9$ Monate: 15 \\
& $>9$ Monate: 20 \\
Motile Spermien (\%) & 70 \\
Motile Spermien bis 72 Std. Konservierung (\%) & 65 \\
Morphologisch anomale Spermien & $\leq 25$ \\
einschl. Spermien mit Plasmatropfen (\%) & $\leq 5$ \\
Spermien mit Kopfveränderungen (\%) & $\leq 10$ \\
Spermien mit Kopfkappenveränderungen (\%) & $\leq 15$ \\
Spermien mit Plasmatropfen (\%) & $\leq 15$ \\
Spermien mit Schleifen (\%) & $\leq 15$ \\
Andere morphologische Abweichungen (\%) & keine für Tier und Mensch spezi- \\
Keimgehalt im ersten untersuchten Ejakulat & fisch pathogenen Keime \\
\hline
\end{tabular}

*) bei Ejakulaten mit einem Volumen $>250 \mathrm{ml}$ kann dieser Wert bis zu $20 \%$ unterschritten werden

Das Vorkommen morphologisch veränderter Spermien wird durch diverse Faktoren, wie die Rasse und das Alter der Tiere (Syring, 2008; Buder, 2013), die Jahreszeit, in der das Ejakulat gebildet wurde (Colenbrander et al., 1993; Suriyasomboon et al., 2005; Petrocelli et al., 2015), sowie die Frequenz der Samengewinnung (Bonet et al., 1991; Pruneda et al., 2005) beeinflusst.

Ein Einfluss der Rasse und des Alters auf die Spermaqualität beim Eber wurde in verschiedenen Studien nachgewiesen (Borg et al., 1993; Bertani et al., 2002; Pizzi et al., 2005). Beispielsweise zeigten Szostak \& Burys (2011), dass die Anzahl von veränderten Spermien bei reinrassigen Ebern niedriger war, als bei Hybridrassen. Im Gegensatz dazu weisen einige Studien eine bessere Qualität bei Hybriden nach (u. a. Kawecka et al., 
2008; Wysokinska et al., 2009). Kuster und Althouse (2007) ermittelten ein höheres Ejakulatvolumen und eine höhere Ejakulatdichte bei Kreuzungsrassen.

Ein Effekt des Alters bei der Samengewinnung wurde unter anderem von Szostak \& Burys (2011) untersucht. In ihren Untersuchungen nahm der Anteil von Spermien mit Schwanzdefekten mit steigendem Alter zu. Wolf \& Smital (2009) fanden mit zunehmendem Alter eine größere Anzahl pathomorpher Spermien und - resultierend daraus - eine abnehmende Spermienmotilität. Im Gegensatz dazu fanden Kawecka et al. (2008) weniger missgebildete Spermien mit zunehmendem Alter, wobei in dieser Studie lediglich eine Altersspanne von 230 bis 270 Tagen einbezogen wurde.

Weiterhin können haltungsbedingte Faktoren das Auftreten morphologisch veränderter Spermien bedingen. In mehreren Studien zeigten die Temperatur bzw. die Zuchtsaison einen Einfluss auf die Spermienqualität. Vor allem in den Sommermonaten konnten vermehrt Abweichungen z. B. des Ejakulatvolumens sowie der -dichte gefunden werden (Claus \& Weiler, 1985; Ciereszko et al., 2000). Dörner und Hühn (1991), sowie Suriyasomboon et al. (2005), fanden einen signifikanten Einfluss auf den Anteil pathomorpher Spermien mit einem Höhepunkt in den Sommermonaten. Sancho et al. (2004) fanden bei Ebern bei abnehmender Tageslichtlänge signifikant seltener Spermatozoen mit einem distalen Plasmatropfen, aber ein signifikant höheres Auftreten von unreifen Spermatozoen mit einem proximalen Plasmatropfen.

\subsubsection{Physiologie der Spermienmotilität}

Eine der wichtigsten Voraussetzungen für die Spermienmotilität ist eine morphologisch intakte Geißel mit zentral liegendem Axonem (Cooper \& Yeung, 2000).

Das Axonem ist eine hoch spezialisierte und konservierte Anordnung von Mikrotubuli und durchzieht den Spermienschwanz in seiner vollen Länge (Briz \& Fàbrega, 2013; Hook \& Vallee, 2006). Es besteht, wie in den meisten Flagellen oder Zilien, aus 20 Mikrotubuli, bei welchen zwei zentral liegende Mikrotubuli von neun äußeren Doppeltubuli (Dupletts, bestehend aus je einem A- bzw. $\alpha$ - und einem B-/ $\beta$-Tubulus) umgeben sind, sodass ein $9 \times 2+2$ Komplex entsteht (Hook \& Vallee, 2006; Inaba, 2011), 
der durch Nexinbänder verbunden ist (Abbildung 2-2) (Lindemann \& Lesich, 2010). Diese Struktur wurde erstmals von Afzelius (1959) beschrieben.

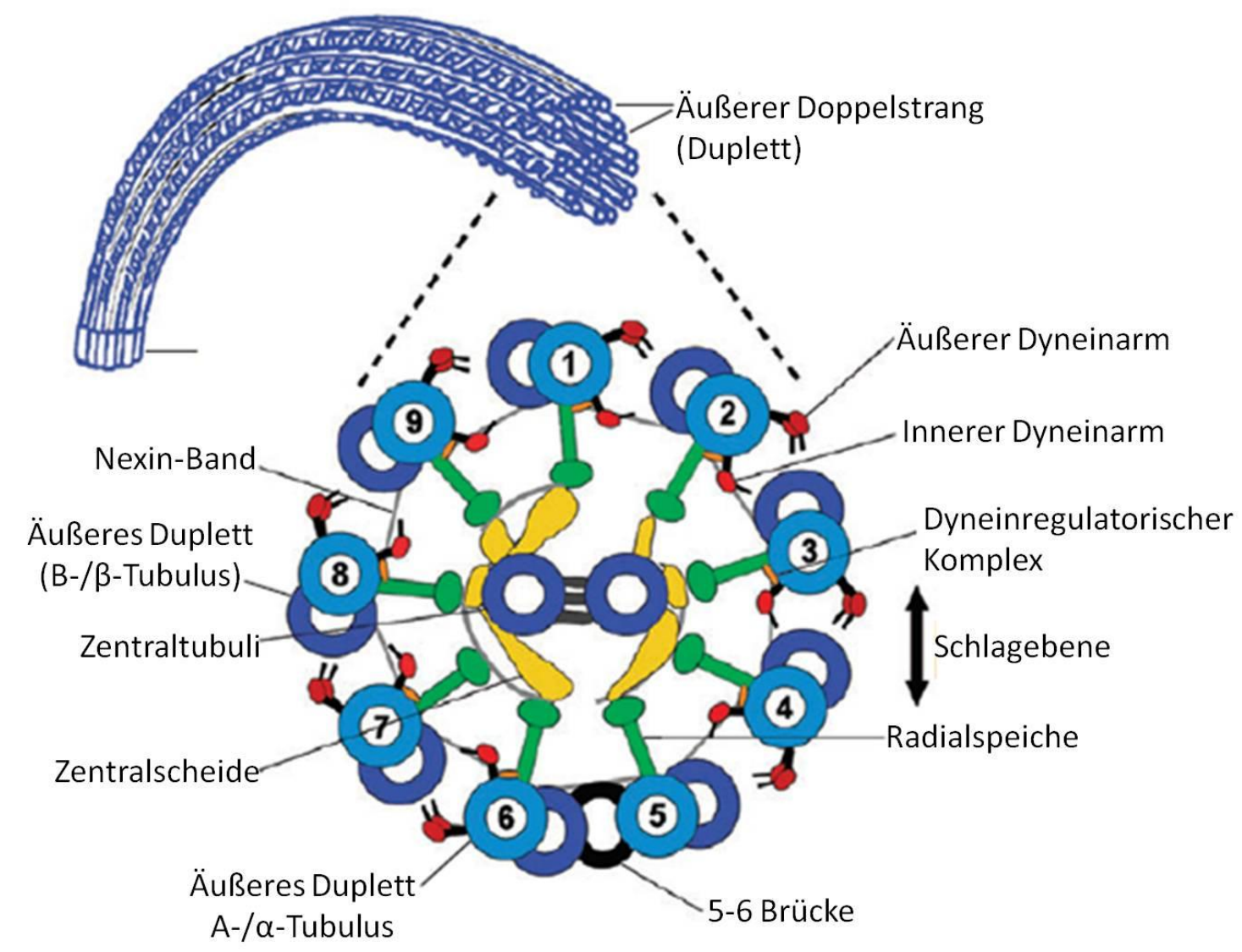

Abbildung 2-2: Schematische Darstellung des flagellären Axonems im Querschnitt (modifiziert nach Lindemann \& Lesich (2010)).

Der Wellenschlag der Geißel basiert auf der wechselnden Aktivierung und Inaktivierung von Dyneinen, welche im Axonem lokalisiert sind (Afzelius, 1959; Cooper \& Yeung, 2000; Shingyoji, 2013). Sie verbinden die äußeren Dupletts miteinander und rufen dadurch ein aneinander Vorbeischieben hervor (Summers \& Gibbons, 1971).

Die äußeren Dyneinarme höherer Organismen bestehen aus zwei schweren Ketten ( 500 kDa) mit zwei zugehörigen Köpfen (Tang et al., 1982; Inaba, 2003; Mohri et al., 2012) sowie drei bis fünf intermediären (60 - 120 kDa) und sechs leichten Ketten (8 30 kDa) (Inaba, 2003; Abbildung 2-3). Die inneren Dyneinarme weisen eine etwas veränderte Struktur auf und bestehen aus mehreren Molekülen mit einem oder zwei Köpfen (Mohri et al., 2012). Dyneine sind neben Myosinen eine Gruppe von mikrotubulären Motorproteinen, die in Eukaryoten den Transport von Zellen oder von Strukturen 
und Bestandteilen innerhalb der Zellen gewährleisten (Hook \& Vallee, 2006) und bei der Umsetzung von Energie als ATPasen wirken (Burgess et al., 2003).

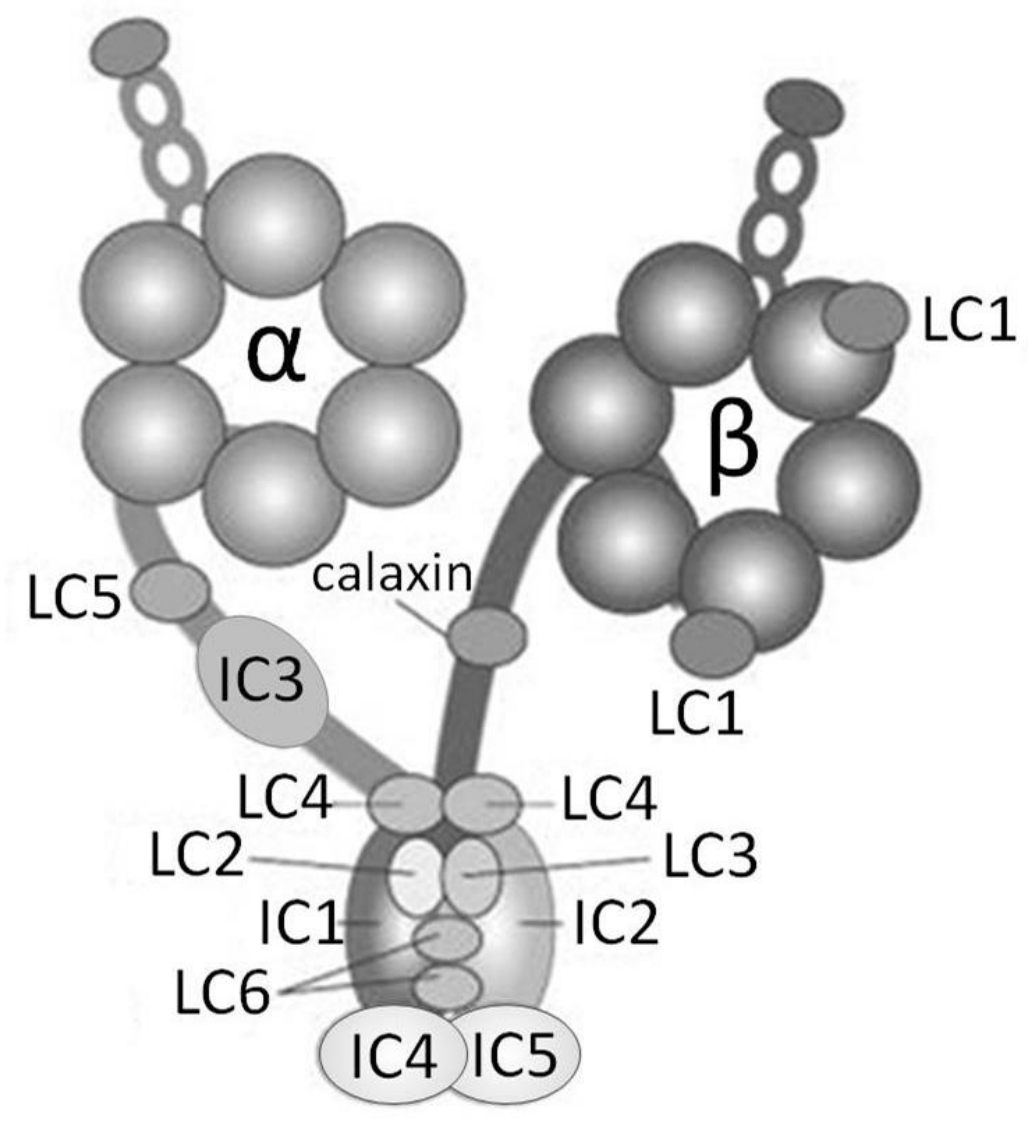

Abbildung 2-3: Schematische Darstellung der Untereinheit des äußeren Dyneinarms (modifiziert nach Mohri et al. (2012)).

LC: Leichte Kette (light chain), IC: Intermediäre Kette (intermediate chain).

Die vom A-Tubulus ausgehende Kontraktion wird dabei an den jeweiligen B-Tubulus des benachbarten Dupletts weitergeleitet und verschiebt diesen in Richtung Axonemende (Sale \& Satir, 1977). Dadurch entsteht eine Biegung des Flagellums in die Richtung der jeweils aktivierten Dyneine (Afzelius, 1959).

\subsubsection{Genetischer Einfluss auf die Spermaqualität}

Obwohl die meisten Fälle pathomorpher Spermien beim Schwein auf Umwelteinflüsse zurückgeführt werden, werden immer mehr der genetisch bedingten strukturellen Veränderungen bekannt (Chenoweth, 2005). Die Erblichkeit spermatologischer Para- 
meter ist niedrig bis moderat und liegt in einer ähnlichen Größenordnung wie beispielsweise die Heritabilität für Wurfgröße (Wolf \& Smital, 2009). Heritabilitäten für Ejakulatvolumen, Spermienmotilität, Spermiendichte, Anteil pathomorpher Spermien (\%), Gesamtanzahl Spermien und Anzahl funktionsfähiger Spermien in einem Ejakulat liegen im Bereich von $h^{2}=0,1-0,42$ (Smital et al., 2005; Wolf, 2009, 2010). Wolf \& Smital (2009) nahmen für die Spermienmotilität eine Heritabilität von 0,13 an. In einer weiteren Studie ging Wolf (2009) von Heritabilitäten zwischen 0,06 und 0,16 aus. Zwar konnten mithilfe klassischer Zuchtmethoden sehr gute Verbesserungen für Merkmale mit moderaten bis hohen Heritabilitäten erzielt werden, jedoch ist die konventionelle Zuchtwertschätzung nicht effizient genug, um eine tierzüchterische Verbesserung von Merkmalen mit niedrigen Heritabilitäten zu erzielen (Zhang et al., 2011; Boichard et al., 2016). Dies wurde durch die Etablierung der genomischen Selektion möglich, mit welcher Zuchtwerte auf Basis von genetischen Markern und mit hoher Genauigkeit geschätzt werden können (Meuwissen et al., 2001; Zhang et al., 2011).

Molekulargenetische Methoden haben es ermöglicht quantitative Marker (quantitative trait loci, QTL) zu lokalisieren und Kandidatengene für die männliche Fruchtbarkeit beim Schwein zu identifizieren. Lin et al. (2006) fanden signifikante Assoziationen zwischen dem Gonadotropin-releasing hormone receptor-Gen (GNRHR) und der Spermienmotilität, der Anzahl abnormaler Spermien $(p<0,05)$ sowie dem Vorkommen von Plasmatropfen $(p<0,005)$. Xing et al. (2009) detektierten 14 mögliche porzine QTL für Spermaparameter, sowie einen SNP im kodierenden Bereich des EstrogenReceptor-1-Gens (ESR1), der mit Spermienmotilität assoziiert wird (Gunawan et al., 2011). In einer Folgestudie wurde das Estrogen-Receptor-2-Gen als Kandidatengen für Eberfruchtbarkeit angenommen (Gunawan et al., 2012). Diniz et al. (2014) fanden einen Zusammenhang zwischen dem Mitochondrial methionyl-tRNA formyltransferaseGen (MTFMT) und der Spermienmotilität. Außerdem identifizierten Kaewmala et al. (2011) einen SNP im Tetraspanin-29-Gen (CD9) auf dem porzinen Chromosom 5 (SSC5) (Yubero et al., 2003) als QTL für Spermienmotilität und den Anteil von Plasmatropfen sowie pathomorphen Spermien. Als weiteres mögliches Kandidatengen ist das Dynein, axonemal, light chain 4-Gen (DNAL4) zu nennen. Dieses ist ebenfalls auf SSC5 lokalisiert und kodiert für eine Untereinheit einer leichten Kette der Dyneine (Uhlmann et 
al., 2007). Daher ist es aufgrund seiner Nähe zu CD9 ein positionelles und außerdem ein mögliches funktionelles Kandidatengen für morphologische Spermaparameter als auch für Motilitätsparameter.

Das Hauptziel der vorliegenden Studien war es, Assoziationen zwischen Varianten des DNAL4-Gens und spermatologischen Parametern zu ermitteln. In einer Eingangsstudie wurden dafür Einflussfaktoren auf das Vorkommen verschiedener morphologischer Spermienanomalien analysiert (Kapitel 2.2) und die erzielten Ergebnisse auf Assoziationen mit SNPs des porzinen DNAL4-Gens untersucht (Kapitel 2.3). 
2.2 Analyse von morphologisch veränderten Spermien in Ejakulaten von Besamungsebern

S. Jansen ${ }^{1}$, A.R. Sharifi ${ }^{2}$, C. Knorr ${ }^{1}$, Isabel Wiedemann ${ }^{1}$

${ }^{1}$ Abteilung Biotechnologie und Reproduktion landwirtschaftlicher Nutztiere, DNTW, Georg-August-Universität Göttingen; Burckhardtweg 2, 37077 Göttingen

${ }^{2}$ Abteilung Tierzucht und Haustiergenetik, DNTW, Georg-August-Universität Göttingen; Albrecht-Thaer-Weg 3, 37075 Göttingen

veröffentlicht in

Züchtungskunde 89(4), 300-310

ISSN 0044-5401

(C) Verlag Eugen Ulmer, Stuttgart 


\section{Zusammenfassung}

Ziel der vorliegenden Studie war es, die genetischen und umweltbedingten Einflussfaktoren auf das Vorkommen verschiedener morphologischer Spermienanomalien zu analysieren. Gegenstand der Auswertung waren 1.543 morphologische Ejakulatuntersuchungen, die von 57 Ebern der Rassen BHZP 77 (Piétrain-Linie db.77${ }^{\circledR}$ ), Deutsches Edelschwein, Deutsche Landrasse sowie Piétrain stammten. Bei der lichtmikroskopischen Analyse der abnormen Spermien erfolgte die Differenzierung in verschiedene morphologisch-anatomische Abweichungen (Kopffehler, Kopfkappenveränderung, Schwanzfehler und Protoplasmatropfen). Die statistische Auswertung mittels der SAS-Prozedur Glimmix berücksichtigte neben dem zufälligen Tiereffekt auch die fixen Effekte Rasse, Alter und Saison. Ein signifikanter Einfluss $(p<0,05)$ der Rasse zeigte sich nur für das höhere Vorkommen von Protoplasmatropfen beim Deutschen Edelschwein. Signifikante Effekte $(p<0,05)$ der Saison wurden, mit Ausnahme der Protoplasmatropfen, auf alle Anomalien nachgewiesen. Für den Alterseffekt zeigten die Ergebnisse für alle Abweichungen einen klaren Anstieg der Pathomorphospermie mit zunehmendem Alter. Weiterhin erfolgte eine Zuchtwertschätzung für das Merkmal Inzidenz der einzelnen Anomalien. Hierbei bestand populationsübergreifend eine deutliche Differenzierung der Zuchtwerte für alle Arten von Anomalien. Insgesamt kann die Selektion auf reduzierte Spermienanomalien daher zu einer Verbesserung der Spermaqualität und damit verbunden zur Verbesserung der Fertilität der Eber führen.

Schlüsselwörter: Spermienmorphologie, Eber, Spermaqualität, Zuchtwert, Fertilität 


\section{Summary}

\section{Analysis of aberrant spermatozoa in ejaculates of Artificial Insemination boars.}

The aim of this study was the determination of genetical and environmental factors that affect the occurrence of aberrant spermatozoa. The evaluation comprised 1,543 ejaculates collected from 57 boars representing BHZP 77 (Piétrain line db.77 ${ }^{\circledR}$ ), German Large White, German Landrace and Piétrain. The morphological investigation was done using standard protocols. Ejaculates were analysed with an optical microscope and abnormal sperm cells were differentiated into varying morphological abnormalities such as abnormal heads, apical ridge defects of the acrosome, abnormal tails and cytoplasmic droplets. The statistical evaluation using the SAS-procedure Glimmix considered the fixed effects breed, age and season besides the random animal effect. $A$ significant effect $(p<0.05)$ of breed on the elevated occurrence of cytoplasmic droplets was found in German Large White boars. Although there were significant effects $(p<0.05)$ of the season on each anomality - except for the cytoplasmic droplets - a significant increase of the anomalities during summer did not exist. There was an age dependent effect on all investigated anomalities $(p<0.05)$. Additionally, the breeding value was calculated for the incidence of individual anomalities. In this context there were clear differences between populations considering the different kinds of anomalities. In total, the data suggest that selection on a reduced number of sperm cell anomalities might lead to an improvement of sperm quality parameters and will therefore enhance boar fertility.

Keywords: Sperm morphology, boar, sperm quality, breeding value, fertility 


\section{Einleitung}

Der zunehmende Spezialisierungsgrad in der Schweineproduktion führte dazu, dass sich die Künstliche Besamung als Standardverfahren der Anpaarung etablieren konnte, da sie einen hohen Reproduktionserfolg gewährleistet. Grundlegende Voraussetzung hierfür ist jedoch die kontinuierliche Überprüfung der Ejakulatqualität und -quantität, um die Fertilität der gewonnenen Ejakulate abzuschätzen (BONET 1990, ČEŘOvskÝ et al. 2005). In Hinblick auf die Spermienmorphologie stellt der Zentralverband der Deutschen Schweineproduktion e.V. (ZDS) diesbezüglich folgende Gewährschaftsbedingungen an Ejakulate: $\leq 5 \%$ kopfveränderte Spermien, $\leq 10 \%$ kopfkappenveränderte Spermien, $\leq 15 \%$ Protoplasmatropfen sowie $\leq 15 \%$ Schwanzfehler bzw. schleifen. Der Prozess der Nebenhodenreifung der Spermien führt zu einer heterogenen Spermien-Zellpopulation in Bezug auf den Reifegrad und die Morphologie (BRIz et al. 1995). Das Vorkommen pathomorpher Spermien wird durch diverse Faktoren wie der Rasse und dem Alter der Tiere (SYRING 2008, BUDER 2013), der Jahreszeit, in der das Ejakulat gebildet wurde (COLENBRANDER et al., 1993, SURIYASOMBOON et al., 2005) sowie der Frequenz der Ejakulationen (BONET et al., 1991, PRUNEDA et al., 2005) beeinflusst. In bisher publizierten Untersuchungen erfolgte die Betrachtung jedoch selten differenziert in die verschiedenen Typen morphologisch-anatomischer Anomalien. Ziel dieser Studie war es daher, auf Basis erfasster morphologischer Daten einer Schweinebesamungsstation die Einflussfaktoren auf das Vorkommen verschiedener Spermienanomalien zu analysieren.

\section{Material und Methoden}

Bei den in die Untersuchung einbezogenen Tieren handelte es sich um 57 Eber der Besamungsstation Göttingen. Die Tiere lassen sich hierbei den Rassen Piétrain-Linie db.77 ${ }^{\circledR}(B H Z P 77, n=4)$, Deutsches Edelschwein $(D E, n=5)$, Deutsche Landrasse (DL, $\mathrm{n}=5)$ sowie Piétrain $(\mathrm{Pi}, \mathrm{n}=43)$ zuordnen. Im Rahmen des normalen Entsamungsintervalls wurden von den Tieren durchschnittlich alle drei Tage mit Hilfe eines Phantoms und der Handmethode Ejakulate gewonnen. Die Analyse der 
Spermienmorphologie erfolgte monatlich. Die Präparate wurden hierfür jeweils am Tag der Entsamung hergestellt. So wurden im Zeitraum von Mai 2005 bis Dezember 2013 insgesamt 1.630 gewonnene Ejakulate untersucht. Die Anfertigung der Ausstriche erfolgte nach Axet al. (2000), die Färbung der Präparate mit der Farelly-Methode nach PAUfLER (1974). Die mikroskopischen Untersuchungen wurden mit einem ZeissLichtmikroskop (Primo Star, Fa. Carl Zeiss Microscopy GmbH, Jena) bei 800-facher Vergrößerung durchgeführt. Pro Ejakulat wurden standardmäßig nach SILVERBERG und TURNER (2008) jeweils 100 Samenzellen durch visuelle mäanderförmige Auszählung in normal entwickelte und fehlerhafte Spermien klassifiziert. Dabei wurden die abnormen Spermien entsprechend den morphologischen Differenzierungskriterien von Weitze (2001) wie folgt unterschieden: Kopffehler (KF), KopfkappenVeränderungen (KK), Schwanzfehler (SF) sowie Protoplasmatropfen (PT). Die Anzahl der untersuchten Ejakulate je Eber im Datensatz differierte mitunter stark. Daher wurden für die statistische Auswertung lediglich diejenigen Eber berücksichtigt, für die $\geq 8$ Untersuchungsergebnisse vorlagen. In der Konsequenz gingen somit 1.543 morphologische Untersuchungsergebnisse von 57 verschiedenen Ebern in die statistische Analyse ein.

Um den Einflussfaktor Jahreszeit in die statistische Auswertung zu integrieren, wurde das kalendarische Jahr in vier Saisonabschnitte (S1 - S4) eingeteilt. Es ergab sich diesbezüglich folgender Untersuchungsumfang: S1 (Winter, 20.01. - 19.04., $n=370$ ), S2 (Frühling, 20.04. - 20.07., $\mathrm{n}=371$ ), S3 (Sommer, 21.07. - 20.10., $\mathrm{n}=387$ ), S4 (Herbst, 21.10. - 19.01., $n=415)$. Bei der Zuordnung der Daten wurde die zeitliche Inkongruenz zwischen der Spermatogenese, unter einem etwaigen Einfluss der Jahreszeit, einerseits und dem Vorliegen der morphologischen Ergebnisse andererseits, beachtet. Die angesprochene zeitliche Abweichung ergibt sich hierbei aus der 34-tägigen Spermatogenese und der sich anschließenden 14-tägigen Nebenhodenpassage der Spermien (BUSCH, 2001). Wie in Abbildung 1 dargestellt, wurden die kalendarischen Zeiträume bei der Übertragung der Daten auf die neue Saisonskala in Anlehnung an die zeitliche Inkongruenz, um jeweils 50 Tage nach hinten verschoben. In Abbildung 1 wird dies exemplarisch für die Transformation der Monate Juni bis August zu Saison 3 dargestellt. Dadurch lassen die morphologischen Ergebnisse aus den einzelnen Saisonabschnitten Rückschlüsse auf die Spermatogenese der jeweiligen Kalendermonate zu. Um die er- 
hobenen morphologischen Ergebnisse zur Prüfung eines Alterseffektes zu nutzen, wurde das Alter der Eber zum Zeitpunkt der Samenabgabe herangezogen. Hierbei variierte das Alter der Tiere zum jeweiligen Untersuchungszeitpunkt zwischen knapp sechs und 96 Monaten.

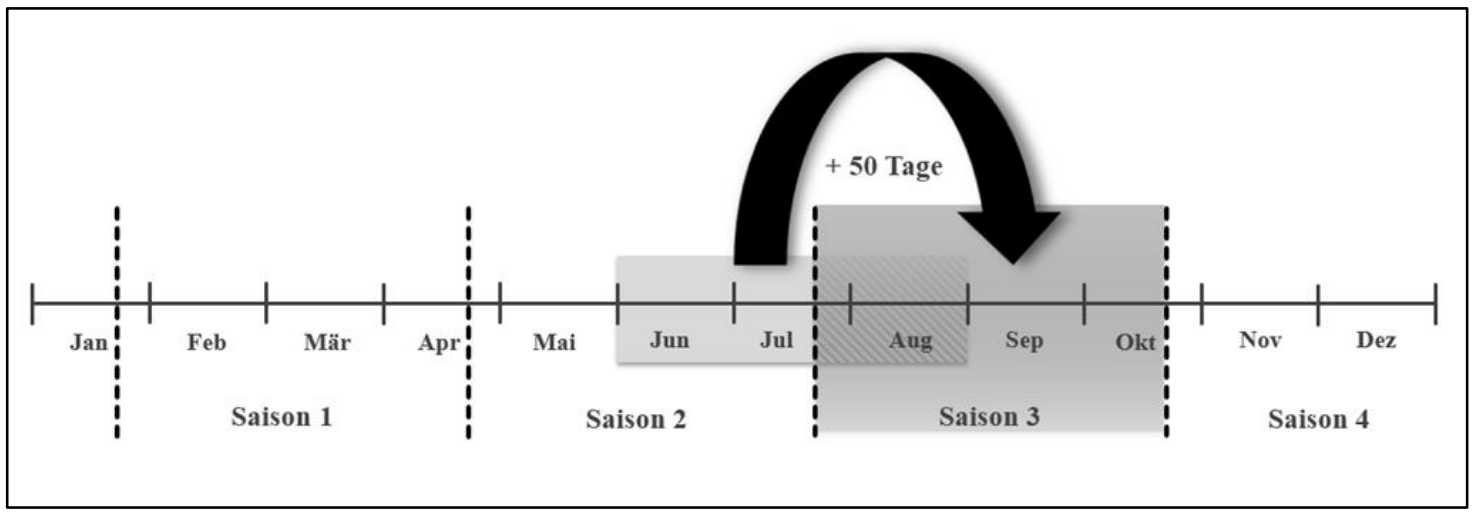

Abb. 1: Schematische Darstellung der Saisoneinteilung zur Analyse des Einflusses der Jahreszeit auf die Spermienmorphologie.

Schematic illustration of seasons' classification for the analysis of a seasonal effect on sperm morphology.

Im Mittel lag es bei näherungsweise 36 Monaten. Für die statistische Auswertung wurden vier Altersklassen (AK, in Monaten) gebildet: AK1 $(X<18 ; n=314)$, AK2 $(18 \leq X<36 ; n=585)$, AK3 (36 $\leq X<54 ; n=367)$, AK4 $(X \geq 54 ; n=277)$.

Das Auftreten der Anomalien wurde als binäres Merkmal kodiert und mittels eines verallgemeinerten linearen Modells der SAS-Prozedur Glimmix (SAS Version 9.4, SAS Institute Inc., Cary, NC, USA) unter der Anwendung des folgenden Modells analysiert:

$$
\begin{array}{ll}
\operatorname{Logit}\left(\pi_{r s t v}\right)=\eta_{r s t v}=\log \left(\pi_{r s t v} / 1-\pi_{r s t v}\right)=\varphi+\alpha_{r}+\beta_{s}+\tau_{t}+\lambda_{v}+\alpha \beta_{r s}+\alpha \tau_{r t}+\beta \tau_{s t}+\alpha \beta \tau_{r s t} \\
\\
\pi_{r s t v} & =\text { Ereigniswahrscheinlichkeit } \\
\varphi & =\text { Gesamteffekt } \\
\alpha_{r} & =\text { fixer Einfluss der Rasse }(r=1,2,3,4) \\
\beta_{s} & =\text { fixer Einfluss der Saison }(s=1,2,3,4) \\
\tau_{t} & =\text { zufälliger Effekt des Ebers } \\
\lambda_{v} & =\text { Effekte der entsprechenden Interaktionen. } \\
\alpha \beta_{r s}, \alpha \tau_{r t}, \beta \tau_{s t}, \alpha \beta \tau_{r s t} &
\end{array}
$$

Die Kleinste-Quadrat-Mittelwerte (LSmeans) wurden zunächst auf der Logit-Skala berechnet und anschließend mittels inverser Link-Funktion $\pi=\frac{\exp (\mathrm{X} \beta)}{1+\exp (\mathrm{X} \beta)}$ auf die ur- 
sprüngliche Skala (Wahrscheinlichkeit) zurück transformiert. Signifikante Unterschiede zwischen LSmeans wurden mittels t-Tests durch Anforderung der PDIFF-Option untersucht.

Der etwaige Einfluss eines Tiereffektes, in diesem Fall definiert als der zufällige Einfluss der Eber auf das Vorkommen morphologischer Anomalien, wurde mittels Verwendung des oben beschriebenen Mischmodels geschätzt und anschließend ebenfalls durch die inverse Link-Funktion auf die ursprüngliche Skala zurück transformiert.

\section{Ergebnisse}

Abbildung 2 zeigt den prozentualen Anteil der Ejakulate, die den jeweiligen vom ZDS definierten qualitativen Gewährschaftsbedingungen entsprachen. Lediglich bezüglich der PT erfüllt ein Großteil der Ejakulate $(92,4 \%)$ die Mindestanforderungen. Hingegen liegen nur bei $88,1 \%$ der untersuchten Ejakulate Kopffehler von weniger als fünf Prozent vor. Der Anteil von Ejakulaten mit kopfkappenveränderten Spermien lag mit $89,1 \%$ knapp unter der geforderten Norm von $90 \%$ und auch in Hinblick auf das Vorkommen von Spermienzellen mit Schwanzfehlern wurde die entsprechende Norm mit $85,6 \%$ nur knapp erreicht.

Abbildung 3 zeigt die rechnerischen Anteile der Ejakulate in Abhängigkeit vom Gesamtanteil der in den Untersuchungen beobachteten veränderten Spermien. Hierbei wird ersichtlich, dass knapp $78 \%$ der untersuchten Ejakulate $\leq 25 \%$ abweichende Spermien, im Umkehrschluss also mindestens 75 \% unveränderte Spermien, aufwiesen. Dies entspricht gleichzeitig den vom ZDS für Eberejakulate geforderten Gewährschaftsbedingungen in Hinblick auf das Gesamtvorkommen morphologisch anormaler Spermien. Wird der Auswertung nun eine strengere Qualitätsanforderung, wie beispielsweise die von ALtHOUSE (1998) geforderten $\leq 20$ \% veränderten Spermien, zu Grunde gelegt, verringert sich der Anteil der Ejakulate, die dieser Qualitätsstufe noch entsprechen, auf 70,1\%. 


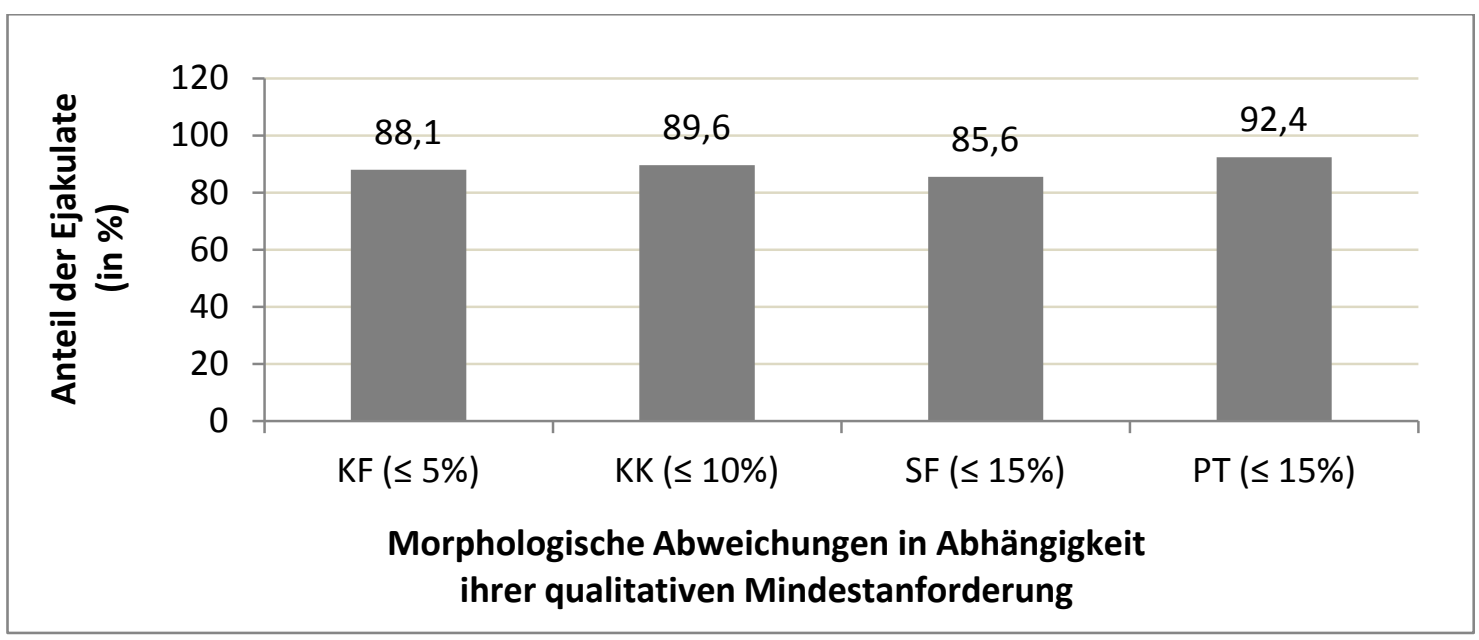

Abb. 2. Anteil der Ejakulate (in \%) in Abhängigkeit von der morphologischen Abweichung sowie ihrer qualitativen Mindestanforderung ( $n=1.543$ ).

Amount of ejaculates (in \%) depending on the type of morphological anomaly and their minimum quality requirement $(n=1,543)$.

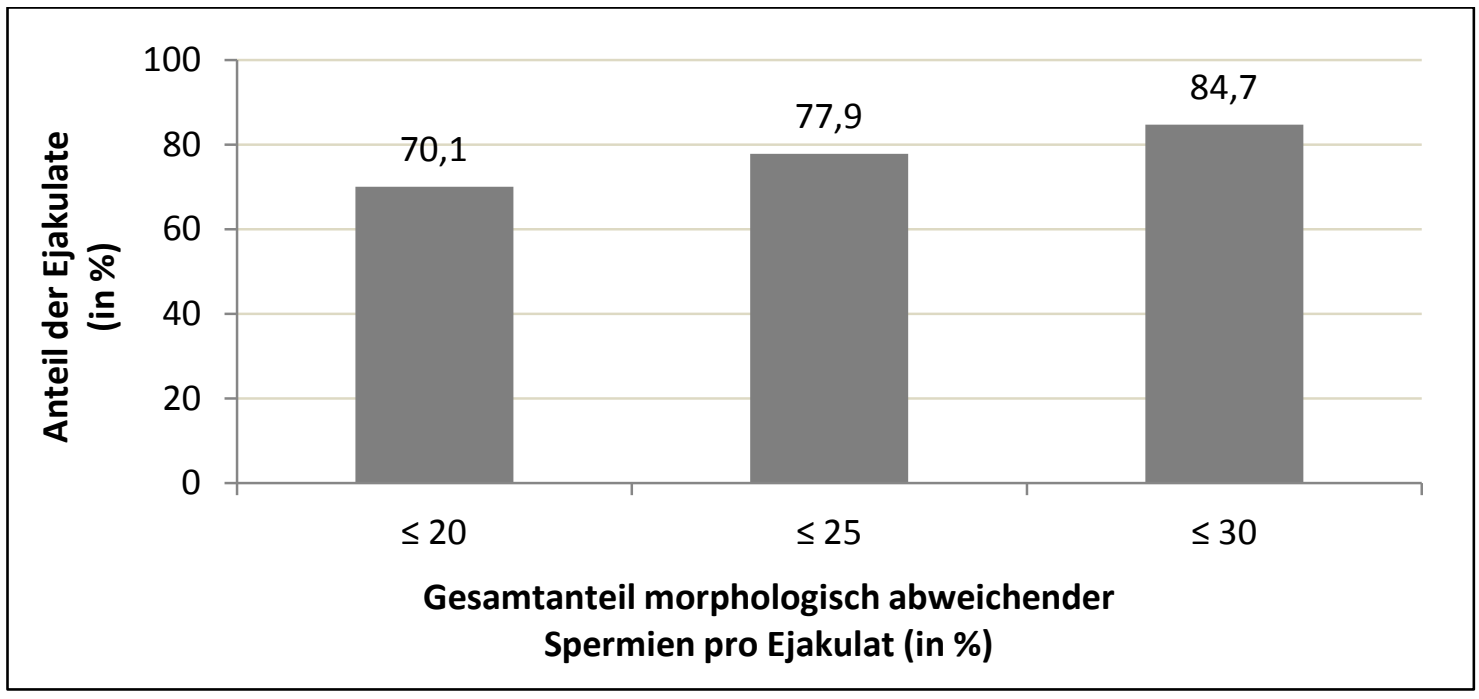

Abb. 3. Anteil der Ejakulate (in \%) in Abhängigkeit vom beobachteten Gesamtanteil morphologisch abweichender Spermien pro Ejakulat $(n=1.543)$.

Amount of ejaculates (in \%) depending on the observed total rate of morphologically abnormal sperms per ejaculate $(n=1,543)$.

Analog hierzu steigt der Anteil der Ejakulate durch eine gleichwertige Reduzierung der Mindestanforderung auf $\leq 30 \%$ pathomorpher Spermien wiederum insofern an, als dass $84,7 \%$ der untersuchten Ejakulate mindestens $70 \%$ normale Spermien aufwie- 
sen. In Bezug auf die Gesamtfrequenz der Anomalien zeigt sich daher, dass für den Großteil der erfassten Ejakulate ein jeweiliger Gesamtanteil veränderter Spermien im unteren zweistelligen Bereich beobachtet werden konnte.

In Tabelle 1 sind die ermittelten Wahrscheinlichkeiten für das Auftreten der vier Anomalien in Abhängigkeit von den fixen Einflussfaktoren Rasse, Saison und Alter wiedergegeben.

Für den Einfluss der Rasse zeigt die Tabelle, dass die Schwanzfehler mit durchschnittlich 5,86\% unter allen Typen morphologischer Anomalien am häufigsten anzutreffen sind. Hierbei sticht die Rasse DL mit einem vergleichsweise hohen Wert $(9,41 \%)$ am deutlichsten aus den sonst relativ ähnlich gelagerten Ereigniswahrscheinlichkeiten hervor. Die Rasseneffekte sind jedoch nicht signifikant abzusichern. Es liegt ein geringer Rasseneffekt auf das Vorkommen von Protoplasmatropfen vor. Die Rasse DE zeigt jedoch mit 6,08\% den mit Abstand höchsten Wert, verglichen mit den anderen drei Rassen, die im Mittel bei 1,17 \% liegen. Signifikante Unterschiede liegen zwischen den Rassen DL und DE vor $(p<0,05)$. Es zeigte sich außerdem, dass Pi-Eber prozentual mehr veränderte Spermienköpfe aufweisen als die anderen Rassen. Letztere liegen im Falle der Kopffehler bei durchschnittlich 1,18 \% und im Falle der Kopfkappenveränderung im Mittel bei 2,29 \%. Der Vergleich zeigt, dass sich die Rasse Pi mit jeweils 1,78\% bzw. 3,46\% auf einem deutlich höheren Niveau bewegt. Die Unterschiede zwischen den Rassen sind jedoch nicht signifikant $(p<0,05)$. Insgesamt konnte ein Effekt der Rasse somit nur bedingt nachgewiesen werden. 
Tab. 1. Ereigniswahrscheinlichkeiten morphologisch veränderter Spermien (in \%) in Abhängigkeit von den fixen Faktoren $(n=1.543)$ (LS-Means \pm SEM)

Mean values and standard errors (LS-Means \pm SEM) of different types of aberrant spermatozoa (in \%) dependent on breed, season and age $(n=1,543)$

\begin{tabular}{l|llll}
\hline & Kopffehler & $\begin{array}{l}\text { Kopfkappen- } \\
\text { veränderungen }\end{array}$ & Schwanzfehler & $\begin{array}{l}\text { Protoplasma- } \\
\text { tropfen }\end{array}$ \\
\hline BHZP 77 & $1,32 \pm 0,51^{\mathrm{a}}$ & $2,54 \pm 1,00^{\mathrm{a}}$ & $5,50 \pm 3,10^{\mathrm{a}}$ & $1,56 \pm 1,12^{\mathrm{ab}}$ \\
DE & $1,13 \pm 0,31^{\mathrm{a}}$ & $2,59 \pm 0,83^{\mathrm{a}}$ & $3,91 \pm 2,00^{\mathrm{a}}$ & $6,08 \pm 3,21^{\mathrm{a}}$ \\
DL & $1,08 \pm 0,32^{\mathrm{a}}$ & $1,74 \pm 0,59^{\mathrm{a}}$ & $9,41 \pm 4,52^{\mathrm{a}}$ & $0,16 \pm 0,16^{\mathrm{b}}$ \\
Pi & $1,78 \pm 0,15^{\mathrm{a}}$ & $3,46 \pm 0,37^{\mathrm{a}}$ & $4,62 \pm 0,80^{\mathrm{a}}$ & $1,78 \pm 0,34^{\mathrm{ab}}$ \\
\hline S1 (20.01. - 19.04.) & $1,79 \pm 0,31^{\mathrm{a}}$ & $2,55 \pm 0,37^{\mathrm{ab}}$ & $6,03 \pm 1,40^{\mathrm{ab}}$ & $2,81 \pm 0,84^{\mathrm{a}}$ \\
S2 $(20.04 .-20.07)$. & $1,53 \pm 0,27^{\mathrm{a}}$ & $3,09 \pm 0,42^{\mathrm{a}}$ & $5,43 \pm 1,27^{\mathrm{b}}$ & $0,93 \pm 0,63^{\mathrm{a}}$ \\
S3 $(21.07 .-20.10)$. & $1,67 \pm 0,28^{\mathrm{a}}$ & $2,18 \pm 0,50^{\mathrm{b}}$ & $4,62 \pm 1,09^{\mathrm{c}}$ & $0,76 \pm 0,48^{\mathrm{a}}$ \\
S4 $(21.10 .-19.01)$. & $0,63 \pm 0,18^{\mathrm{b}}$ & $2,31 \pm 0,42^{\mathrm{b}}$ & $6,27 \pm 1,45^{\mathrm{a}}$ & $1,40 \pm 0,44^{\mathrm{a}}$ \\
\hline AK1 $(X<18)$ & $1,56 \pm 0,13^{\mathrm{c}}$ & $3,03 \pm 0,30^{\mathrm{b}}$ & $3,94 \pm 0,59^{\mathrm{d}}$ & $1,04 \pm 0,18^{\mathrm{d}}$ \\
AK2 $(18 \leq X<36)$ & $1,82 \pm 0,14^{\mathrm{b}}$ & $3,30 \pm 0,31^{\mathrm{b}}$ & $4,41 \pm 0,65^{\mathrm{c}}$ & $1,53 \pm 0,25^{\mathrm{c}}$ \\
AK3 $(36 \leq X<54)$ & $2,02 \pm 0,17^{\mathrm{b}}$ & $3,63 \pm 0,35^{\mathrm{a}}$ & $6,06 \pm 0,88^{\mathrm{b}}$ & $2,45 \pm 0,40^{\mathrm{b}}$ \\
AK4 $(X>54)$ & $2,42 \pm 0,21^{\mathrm{a}}$ & $3,17 \pm 0,32^{\mathrm{b}}$ & $7,94 \pm 1,14^{\mathrm{a}}$ & $4,94 \pm 0,80^{\mathrm{a}}$ \\
\hline
\end{tabular}

Mittelwerte mit gleichen Buchstaben sind nicht signifikant voneinander verschieden (Tukey-Kramer, $\mathrm{p}<0,05$ ).

Means with the same letter are not significantly different (Tukey-Kramer, $p<0.05$ ).

Signifikante Effekte der Saison wurden auf alle Anomalien nachgewiesen, mit Ausnahme des Merkmals Protoplasmatropfen. So war das Auftreten von Kopffehlern in S4 (Herbst) mit 0,63\%, verglichen mit den drei anderen Jahreszeiten, signifikant verringert $(p<0,05)$. Dem gegenüber ist die Wahrscheinlichkeit für kopfkappenveränderte Spermien in S2 (Frühling) mit 3,09 \% signifikant $(p<0,05)$ höher als in S3 (Sommer) sowie S4 (Herbst) mit jeweils 2,18 \% bzw. 2,31 \%. Analog zum Einfluss der Rasse zeigt der Vergleich der Werte für den jahreszeitlichen Einfluss außerdem, dass sich die Inzidenz von Schwanzfehlern mit durchschnittlich 5,9 \% über alle Saisons deutlich von den anderen Anomalien abhebt. Hierbei unterscheidet sich die Saison 4 mit 6,27 \% signifikant von den Saisons 2 und 3. Gleiches wurde zwischen der ersten und dritten Saison ermittelt.

Tabelle 1 zeigt im Falle der Kopffehler, Schwanzfehler und Protoplasmatropfen für den Einfluss des Alters einen signifikanten Anstieg der Anomalien im Verlauf der Altersklassen $(p<0,05)$. In Bezug auf die Schwanzfehler lässt sich nicht nur der mit 3,94 \% (AK1) und 7,94 \% (AK4) deutlichste Anstieg der Werte, sondern im Vergleich zu den 
anderen Anomalien insgesamt auch mit durchschnittlich 5,59 \% die höchste Ereigniswahrscheinlichkeit fehlerhafter Spermien in Abhängigkeit vom Alter finden. Darüber hinaus konnten hierbei für sämtliche aufgezeigten Unterschiede zwischen den Altersklassen Signifikanzen $(p<0,05)$ nachgewiesen werden. Ein derartiger altersbedingter Anstieg lässt sich im Falle der kopfkappenveränderten Spermien nicht erkennen. Jedoch weist Altersklasse 3 mit 3,63\% ein signifikant $(p<0,05)$ höheres Vorkommen morphologisch abweichender Spermien auf als die anderen Altersklassen. Zwar ist die mittlere Ereigniswahrscheinlichkeit von Spermien mit Protoplasmatropfen mit 2,49\% vergleichsweise gering, jedoch lassen die dargestellten Werte eine relativ große Schwankungsbreite erkennen. Hierbei zeigt vor allem der Übergang von der dritten zur vierten Altersstufe (d. $\mathrm{h}$ älter als 54 Monate) mit knapp 2,5 \% einen deutlichen Anstieg von veränderten Spermien. Abschließend sind die statistisch gesicherten Unterschiede zwischen allen vier Altersklassen als signifikant $(p<0,05)$ zu beurteilen.

Abbildung 4 zeigt die Gesamtzuchtwerte der erfassten Eber, rangiert nach dem Grad des geschätzten Zuchtwerts für das Merkmal Ereigniswahrscheinlichkeit respektive Inzidenz der verschiedenen Anomalien. Obgleich keine ausgeprägten Unterschiede im Grad der Spermienanomalien zwischen den Populationen nachzuweisen sind, besteht populationsübergreifend allerdings eine deutliche Differenzierung der geschätzten Zuchtwerte für alle Arten von Anomalien bei allen in die Analyse eingegangenen Ebern. Insgesamt verdeutlicht die Auswertung, dass der eruierte Zuchtwert einer Vielzahl der Tiere eine relativ hohe positive Abweichung vom Mittelwert aufweist. 


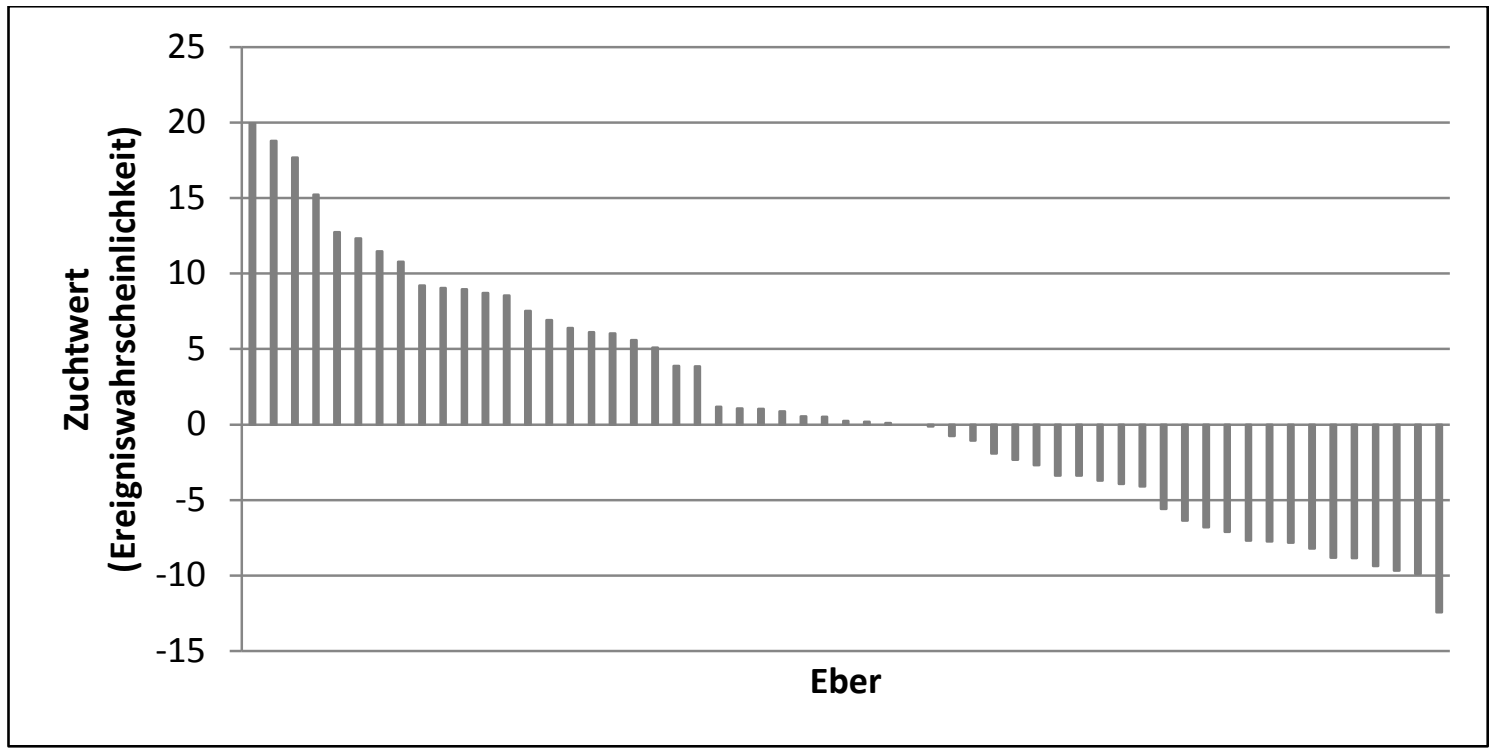

Abb. 4. Gesamtzuchtwerte verschiedener Eber im Hinblick auf morphologisch abweichende Spermien (Kopffehler, Kopfkappenveränderung, Schwanzfehler und Protoplasmatropfen).

Breeding values of different boars with respect of morphologically aberrant spermatozoa (abnormal heads, acrosomal defects, abnormal tails, and cytoplasmic droplets).

\section{Diskussion}

In Bezug auf die Frequenz der Ejakulate mit morphologisch abweichenden Spermien sind hinsichtlich der Spermaqualität die Gewährschaftsbedingungen des ZDS in Deutschland entscheidend. In Hinblick auf den zulässigen maximalen Gesamtanteil morphologisch abweichender Spermien hat der ZDS einen Wert von $25 \%$ als Mindestanforderung festgelegt. Diese Einschätzung eines noch tolerierbaren Anteils pathomorpher Spermien im Ejakulat wird hierbei durch Angaben von BONET (1990), ČEŘOVSKÝ et al. (2005) sowie LIPENSKÝ et al. (2010) unterstützt. In Bezug auf die in dieser Untersuchung erfassten Ejakulate ist mit knapp 78 \% der Großteil der untersuchten Ejakulate der genannten Anforderung von $\leq 25 \%$ morphologisch veränderter Spermien gerecht geworden. Im Umkehrschluss verfehlten jedoch auch 22 \% der Ejakulate den genannten Zielwert, da ihr Gesamtanteil anomaler Spermien den maximal tolerierbaren Wert überschritt. Aufgrund der geltenden Bestimmungen können letztgenannte Ejakulate somit auch nicht in den Verkauf gehen. Mit Blick auf die notwendige 
Wirtschaftlichkeit der Spermaproduktion sollte eine Besamungsstation stets bestrebt sein, den Anteil vermarktungsfähiger Ejakulate zu maximieren. Zudem sollte die morphologische Analyse der Spermazellen unmittelbar am Tag der Entsamung erfolgen, was auf die morphologischen Untersuchungen dieser Studie nicht zutrifft. Hier wurden die Ausstriche 24 Stunden nach der Entsamung angefertigt und bis zur monatlichen Auszählung in dafür vorgesehenen Kästen dunkel und bei Raumtemperatur gelagert.

Wie bereits von BUDER (2013) berichtet, konnte auch in dieser Untersuchung ein signifikanter Einfluss der Rasse auf das Vorkommen von Protoplasmatropfen abgesichert werden. Hierbei stach die Rasse DE mit einer deutlich höheren Ereigniswahrscheinlichkeit aus den anderen Rassen hervor. Weitere signifikante Unterschiede wurden jedoch nicht nachgewiesen. Dies deckt sich zwar mit den Ergebnissen von Borg et al. (1993) Sowie PARK und YI (2002), jedoch ermittelte neben SYRING (2008) insbesondere auch BUDER (2013) im Rahmen einer ausführlichen Literaturanalyse klare Effekte der Rasse auf das Vorkommen weiterer Formen morphologisch veränderter Spermien.

Da sich für den Einfluss der Saison ein sehr heterogenes Bild zeigte, ließ sich die u. a. von DÖRNER und HÜHN (1991) sowie LIPENSKÝ et al. (2010) angeführte deutliche und signifikante Erhöhung der Anomalien im Sommer nicht nachweisen. Im Gegensatz dazu ist bei den Untersuchungsergebnissen dieser Studie jedoch zu verzeichnen, dass die erfassten Anomalien vergleichsweise häufig in der ersten Saison (Winter) beobachtet wurden. Der von BORG et al. (1993) postulierte signifikante Unterschied von veränderten Kopfkappen zwischen Ejakulaten aus dem Frühling, verglichen mit denen des Sommers, wurde jedoch bestätigt. Weiterhin konnte im Herbst ein signifikant höheres Vorkommen von Schwanzfehlern nachgewiesen werden. Dieses Ergebnis deckt sich in gewissem Umfang mit den Resultaten von BUDER (2013). Weiterhin postulierte SYRING (2008) eine tendenzielle Abnahme des Anteils normal ausgebildeter Spermien in den Wintermonaten. In den hier vorliegenden Ergebnissen kann diese Tendenz vor allem durch die Zunahme der Kopffehler, der Kopfkappenveränderungen und der Protoplasmatropfen bestätigt werden. Signifikanzen konnten hierzu jedoch ebenfalls nicht nachgewiesen werden. Bezüglich der Bedeutsamkeit des Alterseffektes ließ sich ein altersbedingter Anstieg der kopfkappenveränderten Spermien zwar nicht erkennen, 
jedoch ist der Prozentsatz in der dritten AK im Vergleich zu den anderen Klassen signifikant erhöht. Analog zu ČEŘovskÝ et al. (2005) wiesen außerdem die Eber der ersten und somit jüngsten AK hinsichtlich aller Anomalien die geringsten Werte auf. Hierbei wurden von ČEŘOVSKÝ et al. (2005) jedoch ein im Verlauf der Jungtierentwicklung anfängliches Absinken der pathomorphen Spermien zur Pubertät sowie ein darauffolgender postpubertärer Wiederanstieg aufgezeigt. Weiterführend wiesen SCHULzE et al. (2014) auf den Zusammenhang zwischen Alter und Spermienmorphologie in Hinblick auf ein etwaiges Mindestalter für die Zuchttauglichkeitsuntersuchungen und der daraus resultierenden Selektionsfähigkeit von Jungtieren hin. Wenngleich auch bei SCHULZE et al. (2014) kein absolutes Mindestalter genannt wurde, erfolgte jedoch der Rat einer Beachtung des beschriebenen Alterseffektes für die praktische Zuchtarbeit und zudem die Etablierung eines altersabhängigen Spermastandards für die Jungeberselektion Insgesamt zeigt sich in den hier vorliegenden Untersuchungsergebnissen, dass, mit Ausnahme der Kopfkappenveränderungen, über alle Altersstufen hinweg ein deutlich signifikanter Einfluss des Alters auf die Inzidenz morphologisch abweichender Spermien postuliert werden kann. Diese Tatsache deckt sich außerdem mit den Ansichten von SYRING (2008) und BUDER (2013).

In Hinblick auf die in Abbildung 4 dargestellten Eber, deren Zuchtwerte positiv vom Mittelwert abweichen, ist anzumerken, dass sich der Begriff der Erblichkeit in dieser Untersuchung auf die genetische Disposition für negative Veränderungen der Spermienmorphologie bezieht. Folglich ist aus Züchterperspektive für die einzelnen Eber ein negativer Zuchtwert anzustreben. Diesbezüglich kann davon ausgegangen werden, dass der Ausschluss genetisch besonders disponierter Eber in den Selektionsstrategien zu einer Verbesserung der Spermaqualität beitragen kann. Allerdings muss die Selektion auf Grundlage einer robusten Zuchtwertschätzung mittels der Einbeziehung möglichst umfangreicher Phänotypen und Pedigree-Informationen sowie der Anwendung eines multivariaten Schätzverfahrens unter Berücksichtigung der verschiedenen Anomalien durchgeführt werden. 


\section{Schlussfolgerungen}

Schlussfolgernd ergab die durchgeführte Analyse in Hinblick auf die fixen Effekte ein insgesamt sehr heterogenes Bild. Eindeutig ließ sich hierbei lediglich der Alterseffekt nachweisen. Im Gegensatz dazu unterscheiden sich die Ergebnisse in Bezug auf den Rasse- sowie den Saisoneffekt zum Teil deutlich von denen der Vergleichsstudien. Weiterhin ist zu beachten, dass aufgrund der deutlich differierenden Beobachtungen innerhalb der einzelnen Rassen, die getätigten Aussagen bezüglich des Rasseeffektes nur eingeschränkt gelten. Vor diesem Hintergrund könnten weiterführende Untersuchungen dazu beitragen, die aufgezeigten Diskrepanzen bezüglich der hier vorliegenden Ergebnisse aufzuklären. Darüber hinaus könnte durch Folgestudien auch der in der Fachliteratur zum Teil bereits nachgewiesene Einfluss weiterer Effekte beleuchtet werden. In diesem Zusammenhang sind beispielsweise der Faktor der Karenzzeit in Zusammenhang mit der Entsamungsfrequenz (PRUNEDA et al., 2005) sowie potenzielle Fütterungs- und Haltungseinflüsse (BUDER, 2013) zu nennen. Die Analyse des zufälligen Effekts des Ebers zeigte sehr deutliche Unterschiede zwischen den ermittelten Zuchtwerten bzw. der genetischen Abweichung der einzelnen Tiere auf. Von daher kann die Selektion auf eine Reduktion des Auftretens von morphologisch veränderten Spermien zu einer genetischen Verbesserung der Spermaqualität und damit verbunden zur Verbesserung der Fertilität der Eber und des Fruchtbarkeitsgeschehens beim Schwein führen.

\section{Autorenbeiträge (Ergänzung zur Veröffentlichung)}

CK Versuchsdesign; SJ: Datenerhebung; RS und SJ: Datenanalyse; SJ und IW: Zusammenstellung der Daten und Verfassen des Manuskripts 


\section{Literatur}

Althouse, G.C. (1998): Cytoplasmic droplets on boar sperm cells. Swine Health and Production, 6 (3): 128.

Ax, R.L., Dally, M., Didion, B.A., Lenz, R.W., Love, C.C., Varner, D.D., Hafez, B. und Bellin, M.E. (2000): Semen evaluation. In: HAFEZ, E.S.E. und HAFEZ, B. (Hrsg.): Reproduction in Farm Animals. 7. Auflage. Philadelphia, Baltimore, New-York, London, Buenos Aires, Hongkong, Sydney, Tokio: Lippincott Williams \& Wilkins.

BONET, S. (1990): Immature and aberrant spermatozoa in the ejaculate of Sus domesticus. Anim. Reprod. Sci., 22: 67-80.

Bonet, S., BRIZ, M. und Fradera, A. (1991): The sperm quality and fertility of boars after two different ejaculation frequencies. Sci. gerundensis, 17: 77-84.

BORG, K.E., LUNSTRA, D.D. und CHRISTENSON, R.K. (1993): Semen characteristics, testicular size, and reproductive hormone concentrations in mature Duroc, Meishan, Fengjing, and Minzhu boars. Biol. Reprod., 49: 515-521.

BUDER, S. (2013): Einflussfaktoren auf die Spermaparameter bei Jungebern - eine Analyse der Daten des Referenzlabors IFN Schönow e. V. aus den Jahren 2001 bis 2011. Dissertation, Tierärztliche Hochschule Hannover.

BusCH, W. (2001): Diagnostische Aussagen spermatologischer Befunde. In: BusCH, W. und HolzmanN, A. (Hrsg.): Veterinärmedizinische Andrologie. 1. Auflage. Stuttgart, New-York: Schattauer Verlag.

Briz, M.D., Bonet, S., PinarT, B., Egozcue, J. und Camps, R. (1995). Comparative study of boar sperm coming from the caput, corpus, and cauda regions of the epididymis. J. Androl., 16 (2), 175-188.

Colenbrander, B., Feitsma, H. und Grooten, H.J. (1993): Optimizing semen production for artificial insemination in swine. J. Reprod. Fertil. Suppl., 48: 207-215.

ČEŘovskÝ, J., FrydrychovÁ, S., LUSTYKovÁ, A. und RozkOt, M. (2005): Relation zwischen dem Gehalt an morphologisch abnormalen Spermien (MAS) im Ebersperma, der Jahreszeit und der Fertilität der künstlich besamten Sauen. In: WÄHNER, M. (Hrsg.): 11. Mitteldeutscher Schweine-Workshop in Bernburg. Bernburg, 20.21.05.2005. Verlag Hochschule Anhalt (FH).

DÖRNER, E. und HÜHN, U. (1991): Zum Vorkommen von Spermaanomalien bei rassedifferenten Besamungsebern im Verlaufe eines Jahres. Arch. Tierz., 34: 391-399.

LIPENSKÝ, J., LUSTYKOVÁ, A. und ČEŘOVSKÝ, J. (2010): Effect of season on boar sperm morphology. J. Cent. Eur. Agric., 11 (4): 465-468.

PARK, C.S. und YI, Y.J. (2002): Comparison of semen characteristics, sperm freezability and testosterone concentration between Duroc and Yorkshire boars during seasons. Anim. Reprod. Sci., 73: 53-61.

PAUfleR, S.K. (1974): Die künstliche Besamung beim Schwein. In: PAUfLER, S.K. (Hrsg.): Künstliche Besamung und Eitransplantation bei Tier und Mensch - Band I. 1. Auflage. Hannover: Verlag M. \& H. Schaper.

Pruneda, A., Pinart, E., Briz, M.D., Sancho, S., Garcia-Gil, N., Badia, E., KÁdÁr, E., Judit, B., Bussalleu, E., YeSTE, M. und BONET, S. (2005): Effects of a high semen-collection frequency on the quality of sperm from ejaculates and from six epididymal regions in boars. Theriogenology, 63: 2219-2232. 
Schulze, M., Buder, S., Rüdiger, K., Beyerbach, M. und WABERSKI, D. (2014): Influences on semen traits used for selection of young Al boars. Anim. Reprod. Sci., 148: 164170.

SilverberG, K.M. und TURner, T. (2008): Evaluation of sperm. In: Gardner, D.K., WEISSMAN, A. und HowLES, C.M.: Textbook of assisted reproductive techniques. $3^{\text {rd }}$ Edition. Zug: Informa Healthcare.

SURIYASOMBOon A., LUNDEHEIM N., KUNAVONGKRITD A. und EINARSSON S. (2005): Effect of temperature and humidity on sperm morphology in Duroc boars under different housing systems in Thailand. J. Vet. Med. Sci., 67: 777-785.

SYRING, C. (2008): Einfluss von Jahreszeit, Rasse und Alter auf die Samenqualität beim Eber. Dissertation, Universität Zürich.

WEITZE, K.F. (2001): Spermatologische Untersuchung. In: BusCH, W. und HolZMANN, A. (Hrsg.): Veterinärmedizinische Andrologie. 1. Auflage. Stuttgart, New-York: Schattauer Verlag.

Zentralverband DER DeUtSCHEN SCHWEINEPRODUKTION E.V. (ZDS) (2005): Gewährschaftsbestimmungen vom 20.10.2005. Anforderungen an Besamungseber hinsichtlich ihrer Eignung zum Einsatz in der KB. Internet: http://www.zdsbonn.de/aktuelles/anforderungen-an-besamungseber-aktualisiert.html [aufgerufen am 06.07.2016]. 


\title{
2.3 SNP g.1007A>G within the porcine DNAL4 gene affects sperm motility traits and percentage of midpiece abnormalities
}

I. Wiedemann ${ }^{1}$, A. Maehlmeyer ${ }^{1}$, S. Jansen ${ }^{1}$, A. R. Sharifi ${ }^{2}$, C. Knorr ${ }^{1}$

${ }^{1}$ Department of Animal Sciences - Livestock Biotechnology and Reproduction, University of Goettingen, Germany

${ }^{2}$ Department of Animal Sciences - Animal Breeding and Genetics, University of Goettingen, Germany

\author{
veröffentlicht in \\ Reproduction in Domestic Animals, 53(2): 401-413 \\ URL: https://onlinelibrary.wiley.com/doi/full/10.1111/rda.13120 \\ DOI: $10.1111 /$ rda.13120
}




\section{Contents}

The flagellar beating of a spermatozoa's axoneme is caused by the varying activation and inactivation of dynein molecules. Dynein, axonemal, light chain 4 (DNAL4) is a functional candidate gene for sperm motility as it encodes a small subunit of the dyneins. We re-sequenced the porcine DNAL4 using three artificial insemination (AI) boars each with high $(>68 \%)$ or low $(<60 \%)$ motility, and detected 23 SNP. These were then genotyped for $82 \mathrm{Al}$ boars. Using spermatological records, significantly negative genetic correlations between ejaculate volume (VOL) and the further spermatological parameters concentration (CONC) $(r=-0.43)$, motility of undiluted semen (MOTUD) $(r=-0.09)$, motility after $24 \mathrm{~h}$ (МOT1) $(r=-0.17)$ and after $48 \mathrm{~h}$ (MOT2) $(r=-0.23)$ were estimated. Significantly positive correlations existed between CONC and MOT1 $(r=0.07)$ as well as MOT2 $(r=0.10)$, between MOTUD and MOT1 $(r=0.33)$, between MOTUD and MOT2 ( $r=0.36)$, and finally between MOT1 and MOT2 $(r=0.70)$. Significantly negatively correlated were all motility traits with the parameters abnormal acrosome (AA) (MOTUD $r=-0.06$; MOT1 $r=-0.08$, and MOT2 $r=-0.1$ ) and presence of cytoplasmic droplet (CD) (MOTUD $r=-0.07$; MOT1 $r=-0.08$; MOT2 $r=-0.07$ ). Association analyses (single marker regression model; SMR) propose that SNP g.1007A>G, located in the second intron, reduces motility significantly (MOTUD -4.59\%; MOT1 -10.33\%; MOT2 -19.37\%). According to the dominant-recessive model (DRM), genotype $A A$ is always superior compared to genotypes $A G$ and $G G$ (i.e., MOTUD 67.67\%, 64.16\% and 53.91\%; MOT1 54.17\%, 43.75\% and 28.44\%; МOT2 44.12\%, $24.91 \%$ and $4.97 \%$ ). The average effect of gene substitution (g.1007A>G) on abnormal midpiece (AM) was $0.71 \%$, the genotypic values - as expressed by LSmeans - were 0.1 $(A A)$ and $0.81(A G)$. 


\section{Introduction}

The process of epididymal maturation of spermatozoa leads physiologically to a heterogenous sperm cell population in terms of maturation degree and morphology. Sperm cell morphology is, however, an essential criterion for the assessment of the ejaculate's fertilizing ability (Briz et al., 1995). Xu et al. (1998) proposed for example that the percentage of spermatozoa showing normal morphology explained about 59\% of the variance in litter size. Therefore, proper analysis of morphological malformations such as head, midpiece and tail defects, is an important part of routine seminal appraisal of boar ejaculates (Bonet et al., 2013). Inaccuracy or lack of precision during semen evaluation is likely to result in insemination doses containing too few or too many sperm cells (Christensen et al., 2004).

In addition, fertility is highly correlated with the number of motile spermatozoa inseminated (Love, 2011) as a progressive motility of less than $60 \%$ negatively affects other fertility parameters (Jung et al., 2015). Tardif et al. (1999) proposed earlier that sperm motility is one of the most important indicators of fertility capacity that must therefore carefully be evaluated (Haidl et al., 1991). Progressive motility is subjected to a proper flagellar movement of a spermatozoa's tail depending on the axoneme, which is in turn subjected to different regulatory systems in the mid and principal piece (Harris et al., 2007). Flagellar beating is thereby caused by the varying activation and inactivation of microtubule motor proteins of the dynein family (Sale \& Satir, 1977).

Both genetic (Wolf, 2009) and environmental factors such as age of boar (Smital, 2009; Wolf \& Smital, 2009), ambient temperature or season (Einarsson et al., 2008; Wolf \& Smital, 2009) affect spermatological traits. Semen quality traits have shown low to medium heritabilities in pigs. Heritabilities have been estimated for semen volume $\left(\mathrm{h}^{2}\right.$ $=0.2-0.6)$ and sperm concentration $\left(h^{2}=0.18-0.5\right)$. Heritabilities of motility, percentage of abnormal spermatozoa, total number of spermatozoa, and number of functional spermatozoa have been in the range between 0.10-0.42 (e.g. Smital et al., 2005; Wolf, 2009, 2010). For motility, Wolf and Smital (2009) have proposed heritabilies of 0.13. In a further investigation Wolf (2009) has postulated values between 0.06 and 0.16. Moreover Smital et al. (2005) have detected even higher heritabilities between 0.34 and 0.58 for semen traits (i.e. volume, progressive motility, concentration, num- 
ber of abnormal spermatozoa) compared to the one known for female reproductive traits like conception rate, number of piglets born and piglets born alive that ranged from $<0.1$ to 0.29 .

Molecular genetic tools enabled to identify quantitative trait loci (QTL) and to search for candidate genes controlling male reproductive traits in pigs. Lin et al. (2006) have revealed significant associations of the Gonadotropin Releasing Hormone Receptor $(G N R H R)$ gene with motility $(p=0.0161)$, plasma droplet rate $(p=0.0048)$ and abnormal sperm rate $(p=0.0201)$. Xing et al. (2009) have detected 14 suggestive QTL for semen and ejaculation traits, and a SNP within the coding region of the Estrogen Receptor 1 gene (ESR1) has been associated with sperm motility (Gunawan et al., 2011). Later the Estrogen Receptor 2 gene (ESR2), located on SSC1, has further been proposed as candidate gene for boar fertility (Gunawan et al., 2012). Finally, SNP (g.358A >T) in the Tetraspanin-29-gene (CD9) located on SSC5q25 (Yubero et al., 2003) has been identified as QTL for sperm motility, plasma droplet rate and abnormal spermatozoa rate by Kaewmala et al. (2011).

The DNAL4 gene encodes a small subunit of dyneins (Uhlmann et al., 2007), and is thus a further possible functional candidate gene for sperm motility. Due to its localization on SSC5p15 and its vicinity to CD9 it is also a positional candidate gene for morphological traits. Prior to our study, Uhlmann et al. (2007) characterized the porcine DNAL4 gene that encompasses 4 exons and consists of 105 amino acids. The main aim of the present study was to assess associations between single nucleotide polymorphisms (SNP) in the porcine DNAL4 gene and spermatological parameters. DNAL4 was thus resequenced using Al boars with high and low motilities to detect existing SNP that were further genotyped for 82 Al boars. Possible associations with qualitative and morphological spermatological parameters were estimated.

\section{Materials and Methods}

The study was done according to the German Animal Welfare Law (released on $15 / 08 / 2006$, last changes on $12 / 03 / 2015)$. 


\subsection{Animals and collection of phenotypes:}

A total of 82 blood samples or ejaculates of 67 Piétrain (PI), 8 German Large White (LW), and 7 German Landrace (LR) boars that were kept at the artificial insemination station Göttingen were used. The spermatological parameters ejaculate volume (VOL), sperm concentration (CONC) and progressive motility (undiluted (MOTUD), after $24 \mathrm{~h}$ (MOT1) and after 48h (MOT2) of semen collection) were recorded between September 2009 and December 2013. The data set 1 included a total of 8,833 observations, which ranged from 2 to 295 per boar. Besides that morphological measurements (presence of cytoplasmic droplet (CD), abnormal tail (AT), abnormal midpiece (AM), abnormal head $(\mathrm{AH})$ and abnormal acrosomal area $(\mathrm{AA}))$ were recorded for a subset of $56 \mathrm{Al}$ boars (46 PI, 5 LW, 5 LR) spanning January 2009 to December 2013 (data set 2). That data set included 1,173 observations ranging from 1 to 42 per boar.

\subsection{Semen collection and trait recording}

Semen was collected manually using a portable steel dummy and a pre-warmed $\left(35^{\circ} \mathrm{C}\right)$ double-layered plastic bag. The ejaculate was then filtered through a five-layered gauze into a pre-warmed graduated cylinder to separate the semen-damaging bulbourethral gland secretion and to quantify the volume $(\mathrm{ml})$. The concentration of the ejaculate was determined photometrically after dilution of the native ejaculate $(1: 100)$ in a $0.9 \% \mathrm{NaCl}$ solution using a Biochrom Libra S4 photometer (Biochrom, UK) at a wavelength of $546 \mathrm{~nm}$ following calibration of the standard curve. A single technician estimated the progressive motility of all investigated ejaculates during the recording period. A drop of the native ejaculate was placed on a microscope slide of a phasecontrast microscope heating stage $\left(37^{\circ} \mathrm{C}\right)$. According to the estimated progressive motility MOTUD (between $0 \%$ and $80 \%$ ), the suitable ejaculates were diluted using Beltsville-TS (BTS) extender (Minitube, Germany) and stored in $100 \mathrm{ml}$ doses according to the following scheme:

$$
\text { number of portions per ejaculate }=\frac{\text { total volume } \times \text { concentration }}{\text { sperm cells per portion }}
$$


Native ejaculates with a MOTUD between $70-80 \%$ were diluted to $2 \times 10^{9}$ sperm cells/tube, those between $65-68 \%$ to 3 bn sperm cells/tube. Ejaculates with less than $<65 \%$ motility were not sold to costumers and discarded. Only marketable tubes were stored in an incubator adjusted to 16 to $18^{\circ} \mathrm{C}$. The progression of motility per ejaculate was estimated using aliquots after $24 \mathrm{~h}$ and $48 \mathrm{~h}$ of storage. This quality control was routinely done as sows in estrus are commonly inseminated twice or three times with boar ejaculates one or two days after semen collection. Double or even triple inseminations about $12 \mathrm{~h}$ after onset of estrus increase litter size according to Xue et al. (1998).

\subsection{Estimation of sperm morphology parameters}

Monthly, smear of the ejaculates were prepared to assess morphological abnormalities. The native ejaculates were diluted $1: 1$ in a $0.9 \% \mathrm{NaCl}$ solution and streaked on a microscope slide. Smeared slide glasses were air-dried, fixed in $5 \%$ formalin and stained by the Farelly method according to Paufler (1974) for 30 sec in $5 \%$ methyl blue (Minitube, Germany), and $10 \mathrm{sec}$ in a $0.5 \%$ crystal violet solution (Minitube, Germany). The presence or absence of a cytoplasmic droplet as well as abnormal tail, midpiece, head and acrosome structures were determined using light microscopy (Zeiss, Germany) at a 30x magnification. For each slide 100 sperm cells were counted according to Silverberg \& Turner (2008) in a meandering pattern. AT include hairpin, coiled or bent $\left(>90^{\circ}\right)$ tails. AM is defined as thickened, shifted or fractured midpieces. AH include amorphous heads such as large, small, tapered, pyriform and round heads. AA describes heads with a distorted, crooked, small or missing acrosomal area. Furthermore the presence of proximal or distal CD was recorded. In case of several defects per sperm cell only one morphological abnormality was recorded. The sequence was $\mathrm{AH}$, $A A, A M, A T$, and $C D$. 


\subsection{DNA Extraction and Quantification}

DNA was extracted either from EDTA conserved blood samples or native ejaculates using a modified salting out procedure according to Miller et al. (1988). For the DNA extraction from semen cells, DTT was added to cleave the disulfide bridges of the nucleoprotamines. The DNA concentration was measured at a wavelength of $260 \mathrm{~nm}$, the purity of DNA was assessed by the absorbance at $280 \mathrm{~nm}$ with a NanoPhotometer ${ }^{\circledR}$ P-360 spectrophotometer (Implen, Germany). The absorbance ratio at 260/280 nm was between 1.81 and 2.10, indicating that all DNA samples were free from protein contaminations.

\subsection{Search for polymorphisms, PCR conditions and genotyping}

SNP in the porcine DNAL4 gene were detected by comparable sequencing throughout the coding, the non coding region as well as the $3^{\prime}$-flanking region with DNAs obtained from three boars (at the age of 6 months to 3.5 years) each with high (>68\%) or low (<60\%) motility as template. The declarations 'high motility' and 'low motility' boar were done by considering the average MOTUD of the preceding year. Primers (Sigma Aldrich, Germany) were designed with the online software Primer 3 (http://bioinfo.ut.ee/primer3-0.4.0/) according to the porcine DNAL4 gene sequence deposited under GenBank Acc. No. AM284969.1. Primers covering exons 1, 2 and 3 were taken from Uhlmann et al. (2007). All primers used in this study including their applications are given in Table 1.

PCR-products were amplified using 20 to $50 \mathrm{ng} / \mu \mathrm{l}$ of genomic DNA, 5mM dNTPs, 10pM of each primer and 1.5U FastStart Taq-Polymerase in $1 \times$ PCR buffer containing $\mathrm{MgCl}_{2}$ (Roche, Switzerland) in a final volume of $25 \mu$ l. The PCR for intron 1 was carried out with an additional concentration of $1 x$ Sulfolan (Sigma Aldrich, Germany). Amplification of exons 1, 3 and 4 required an additional concentration of 1x Q-Solution (Qiagen, Germany) in the reaction mix. PCRs were performed in a Biometra T3000 thermal cycler (Biometra, Germany) with the following thermal profile: 35 cycles (intron 1: $38 \mathrm{cycles}$ ) of $30 \mathrm{sec}$ at $95^{\circ} \mathrm{C}, 30 \mathrm{sec}$ at the specific annealing temperature (Table 1) and 
$30 \mathrm{sec}$ at $72^{\circ} \mathrm{C}$ with both an additional 10 min denaturation in the first cycle and an extra extension for $5 \mathrm{~min}$ in the last cycle. The fragment identity was checked by separation on $1.5 \%$ agarose gels.

Table 1: DNAL4 primers referred to GenBank Acc. No. AM284969.1

\begin{tabular}{|c|c|c|c|c|c|}
\hline Exon/Intron & Primer & Sequence (5'-3') & $\begin{array}{c}\text { Position in } \\
\text { DNAL4 }\end{array}$ & $\begin{array}{c}\text { Fragment } \\
\text { length (bp) }\end{array}$ & Analysis \\
\hline \multirow{2}{*}{ Exon 1} & For & ATG AGA ACT TCT GCG TGT GG & $308-327$ & \multirow{2}{*}{414} & \multirow{2}{*}{ Sequencing } \\
\hline & Rev & AAC AGG CAG GAG ACT GAG GA & $702-721$ & & \\
\hline \multirow{2}{*}{ Intron 1} & For & CAT TGC GGG ACG GGC GGA & $661-687$ & \multirow{2}{*}{470} & \multirow{2}{*}{ Sequencing } \\
\hline & Rev & TTG CCC AGT CCT TTT CAT TC & $1,112-1,131$ & & \\
\hline \multirow{2}{*}{ Exon 2} & For & ACG TGT GCT GGG AAG TAA GG & $1,671-1,690$ & \multirow{2}{*}{885} & \multirow{2}{*}{ RFLP } \\
\hline & Rev & CCC TGC ACC TGC TTT ATT TG & $2,536-2,555$ & & \\
\hline \multirow{2}{*}{ Intron 2} & For & CAG GAG AGA ACC GGA CAA AG & $2,452-2,471$ & \multirow{2}{*}{580} & \multirow{2}{*}{ Sequencing } \\
\hline & Rev & CAC CAG GTC TCA CCA CCT CT & $3,013-3,032$ & & \\
\hline \multirow{2}{*}{ Exon 3} & For & CCT GTC AGG AGA TGG GTC AT & $3,593-3,612$ & \multirow{2}{*}{358} & \multirow{2}{*}{ Sequencing } \\
\hline & Rev & TTC CAA GGA AGG AAG GCT CT & $3,931-3,950$ & & \\
\hline \multirow{2}{*}{ Exon 4} & For & CGA GCA GTT TCT CCA AGA GTC & $4,899-4,916$ & \multirow{2}{*}{438} & \multirow{2}{*}{ Sequencing } \\
\hline & Rev & TCC TGA TGA GCG TCC ACA G & $5,416-5,434$ & & \\
\hline
\end{tabular}

Genotyping was done by sequencing of PCR products using an ABI PRISM 3100 Genetic Analyzer (Applied Biosystems, Germany) and the BigDye ${ }^{\mathrm{TM}}$ Terminator v3.1 Cycle Sequencing Reaction Kit (Applied Biosystems, Germany). Prior to that, samples were purified with ExoStar (Illustra GE Healthcare, Germany) according to the manufacturer's instructions. Afterwards, the sequences were manually analyzed and SNP genotyped using the software DNASTAR Lasergene 12 Core suite (DNASTAR, USA). SNP (g.2290T>A) in intron 2 was genotyped by the RFLP method using $5 \mu$ of the $885 \mathrm{bp}$ long PCR product and $1 \mathrm{U}$ BsmFI (NEB, Germany) in $1 \times$ CutSmart buffer $\left(65^{\circ} \mathrm{C}\right.$ for $3 \mathrm{~h}$ followed by an inactivation step at $80^{\circ} \mathrm{C}$ for $20 \mathrm{~min}$ ). The mutant nucleotide $A$ deletes a polymorphic recognition site for BsmFI leading to a fragment of $477 \mathrm{bp}$ together with the ones of $258 \mathrm{bp}$ and $150 \mathrm{bp}$ that represent two constant recognition sites. The wildtype allele T consists of four fragments with the sizes of $281 \mathrm{bp}, 258 \mathrm{bp}, 196 \mathrm{bp}$, and $150 \mathrm{bp}$. Products were subjected to non-denaturing horizontal gel-electrophoresis in $2 \%$ agarose gels for $45 \mathrm{~min}$ at $120 \mathrm{~V}$ to assess genotypes of the samples. 


\subsection{Statistical analysis}

Different statistical analyses were performed. First of all descriptive statistical analyses were done calculating arithmetic means, standard deviations, and minimum and maximum values of sperm parameters using mean procedure of SAS 9.4 (SAS Institute Inc., USA). Allele frequencies were calculated using the procedure freq of SAS. Furthermore, Pearson's correlation coefficients were used to render the linear dependencies of the semen parameters.

The degree of linkage disequilibrium (LD) between the annotated SNP was estimated using $\mathrm{R}^{2}$-statistics applying genetics packages of $\mathrm{R}$ statistical software. The monomorphic SNP (g.2674_2675insG) was excluded from the association analysis. In case of a complete LD only one SNP was taken for the further statistical analyses. To perform the association analyses a three-step approach was applied. First of all, the newly described SNP and thus so far unknown SNP were used. This was done by comparison of the SNP with the data deposited in the NCBI dbSNP database (http://www.ncbi.nlm.nih.gov/SNP/). Secondly, the position of the SNP within the porcine DNAL4 served as a second selection criterion. Finally, SNP were distributed as evenly as possible.

In order to analyse the effect of a SNP on spermatological traits, both a gene substitution model (SMR) and a model estimating additive and dominance effects (DRM model) was applied using the mixed procedure of SAS software. The gene substitution model estimated the effects of segregating SNP on the traits by single marker regression analysis adjusting for significant fixed factors. The following statistical model was used:

$$
Y_{i j k l}=\mu+B_{i}+S_{j}+B S_{i j}+b_{1} G_{i j}+b_{2} A_{i j}+b_{3} T_{i j}+b_{4} B A_{i j}+b_{5} S A_{i j}+E_{k}+e_{i j k l}
$$

where:

$Y_{i j k}$ : phenotypic value of respective trait,

$\mu$ : the overall mean effect,

$B$ : fixed effect of breed $i(i=3)$,

S: fixed effect of season $\mathrm{j}(\mathrm{j}=4)$, 
$b_{1}$ : regression coefficient of fixed effect of SNP (G),

$b_{2}$ : regression coefficient of fixed effect of age $(A)$ at semen collection,

$b_{3}$ : regression coefficient of fixed effect time duration between semen collections $(T)$,

$\mathrm{BS}_{\mathrm{ij}}$ : fixed interaction effect between breed and season,

$b_{4}$ : regression coefficient for interaction between breed and age,

$E_{k}$ : random (= repeated) effect of the boar, and

$\mathrm{e}_{\mathrm{ijk} \mathrm{k}}$ : residual error.

The estimated $p$-values were adjusted for multiple testing by Bonferroni correction.

SMR models have no power to detect dominance or overdominance effects of heterozygous genotypes. Thus, the SNP effect $(G)$ was considered in the DRM model as fixed class variable using the following model:

$$
Y_{i j k l m}=\mu+B_{i}+S_{j}+G_{k}+B S_{i j}+b_{1} A_{i j k}+b_{2} T_{i j k}+b_{3} B A_{i j k}+b_{4} S A_{i j k}+E_{l}+e_{i j k l m}
$$

where:

$\mathrm{Y}_{\mathrm{ijk} \mid \mathrm{m}}$ : phenotypic value of respective trait,

$\mu$ : the overall mean effect,

B: fixed effect of breed $i(i=3)$,

S: fixed effect of season $\mathrm{j}(\mathrm{j}=4)$,

G: fixed effect of genotypes $\left(j=3 ; j_{1}=1(A / A), j_{2}=2(A / B)\right.$, and $j_{3}=3(B / B)$

$B S_{i j}$ : fixed interaction effect between breed and season,

$b_{1}$ : regression coefficient of fixed effect of age $(A)$ at semen collection,

$b_{2}$ : regression coefficient of fixed effect time duration between semen collections $(T)$,

$b_{3}$ : regression coefficient for interaction between breed $(B)$ and age $(A)$,

$b_{4}$ : regression coefficient for interaction between season $(S)$ and age $(A)$,

$E_{k}$ : random (= repeated) effect of the boar, and

$\mathrm{e}_{\mathrm{ijk} \mathrm{m}}$ : residual error.

The additive effect of two alleles is commonly estimated by comparison of the phenotypic mean values of the homozygote genotypes. The dominance effect describes though the deviation of the phenotypic mean value of the heterozygote genotype from the one assessed using both homozygote genotypes. Therefore least square 
means for the different genotypes were estimated applying the least square means (LSmeans) statement using the mixed procedure of SAS software. Significant differences between least square means were tested using a t-test and adjusted by Bonferroni correction. Table 5 and Table 6 list genotypes $A A, A B$, and $B B$ that represent in a generalized way for the two homozygous and the one heterozygous genotype per SNP. The actual genotypes are listed in Table 4 and are used throughout the text.

Least square means for the different genotypes were estimated applying the least square means (LSmeans) statement using the mixed procedure of SAS software. Significant differences between least square means were tested using a t-test and adjusted by Bonferroni method.

The inverse link function of a generalized linear model (logit link function) is nonlinear and does not give an equal substitution effect particularly for very small incidence rates. Thus, the model parameter for morphological traits were estimated by applying a general linear model (GLM) using a normally distributed response variable with an identity link function.

\section{Results}

\subsection{Phenotypic trait analyses}

The average ejaculate volume was $277.55 \mathrm{ml}$, varying from $50 \mathrm{ml}$ to $550 \mathrm{ml}$. The sperm concentration varied from $0.03 \times 10^{6} / \mu \mathrm{l}$ to $0.6 \times 10^{6} / \mu \mathrm{l}$ and averaged to $0.21 \times 10^{6} / \mu \mathrm{l}$. The mean progressive motility of ejaculates decreased after $24 \mathrm{~h}$ respectively after $48 \mathrm{~h}$ of storage. Morphological abnormalities per slide were equal to 0 up to 80 cases. AT were most common, followed by $A A$ and the presence of $C D$. AH and AM occurred least often (Table 2). There were no significant differences between AH, AA, AT and the investigated genetic backgrounds Piétrain, German Large White and German Landrace. German Landrace boars were, however, superior with respect to CD (results not shown). 
Table 2: Spermatological parameter, number of observations $(N)$, means, ranges of traits standard deviation (S.D.) and standard error of the means (S.E.M.)

\begin{tabular}{crrrrrr}
\hline Parameter & $\mathbf{N}$ & mean & max & min & S.D. & S.E.M. \\
\hline VOL (ml) & 1,172 & 272.55 & 550.00 & 50.00 & 86.04 & 2.51 \\
CONC (mio./ $\mu l)$ & 1,173 & 0.21 & 0.60 & 0.03 & 0.09 & 0.003 \\
MOTUD (\%) & 1,169 & 67.14 & 75.00 & 35.00 & 3.18 & 0.09 \\
MOT1 (\%) & 1,018 & 60.40 & 70.00 & 20.00 & 10.15 & 0.32 \\
MOT2 (\%) & 857 & 50.27 & 70.00 & 0.00 & 18.40 & 0.63 \\
AH (\%) & 1,173 & 2.01 & 80.00 & 0.00 & 4.28 & 0.12 \\
AA (\%) & 1,173 & 4.52 & 72.00 & 0.00 & 6.95 & 0.20 \\
AM (\%) & 1,172 & 0.18 & 58.00 & 0.00 & 1.85 & 0.05 \\
AT (\%) & 1,173 & 7.88 & 80.00 & 0.00 & 9.92 & 0.29 \\
CD (\%) & 1,173 & 3.79 & 74.00 & 0.00 & 8.15 & 0.24 \\
\hline
\end{tabular}

The estimation of associations between different sperm parameters revealed, i.e. a highly significant $(p<0.0001)$, but negative phenotypic correlation $(r=-0.43)$ between VOL and CONC ( $n=1,172$ ) (Table 3). Furthermore we observed significant negative phenotypic correlations between VOL and all motility traits, i.e. MOTUD ( $r=-0.09$; $p=0.003 ; n=1,168)$, MOT1 $(r=-0.17 ; p<0.0001 ; n=1,017)$, and MOT2 $(r=-0.23$; $p<0.0001 ; n=856)$. Contrary to that progressive motilities after storage were positively correlated with higher sperm concentrations of the native ejaculate (MOT1: $r=0.07$; $p=0.02 ; n=1,018 ;$ MOT2: $r=0.10 ; p=0.003 ; n=857)$. In addition, positive relationships have been determined between the three motilities: MOTUD and MOT1 $(r=0.33 ; p<0.0001 ; n=1,018)$, MOTUD and MOT2 $(r=0.36 ; p<0.0001 ; n=856)$ and MOT1 and MOT2 ( $r=0.70 ; p>0.0001 ; n=816)$.

The amount of AA was correlated to the presence of $C D(r=0.12 ; p<0.0001 ; n=1,173)$. The data indicated also significant negative correlations between $A A$ and each of the three motilities MOTUD ( $r=-0.06 ; p=0.05 ; n=1,169)$, МOT1 $(r=-0.08 ; p=0.009$; $1,018)$ and MOT2 $(r=-0.10 ; p=0.005 ; n=857)$. The presence of CD was negatively correlated with progressive motilities (MOTUD: $r=-0.07 ; p=0.01 ; n=1,169$; MOT1: $r=-0.08 ; p=0.01 ; n=1,018 ;$ MOT2: $r=-0.07 ; p=0.04 ; n=857)$. 
Table 3: Pearson's correlation coefficient and significance levels

\begin{tabular}{|c|c|c|c|c|c|c|c|c|c|c|c|}
\hline & & $\begin{array}{l}\text { VOL } \\
\text { (ml) }\end{array}$ & 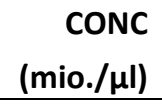 & $\begin{array}{r}\text { MOTUD } \\
(\%) \\
\end{array}$ & $\begin{array}{r}\text { MOT1 } \\
(\%) \\
\end{array}$ & $\begin{array}{r}\text { MOT2 } \\
\text { (\%) } \\
\end{array}$ & $\begin{array}{l}\text { AH } \\
\text { (\%) }\end{array}$ & $\begin{array}{l}\text { AA } \\
(\%)\end{array}$ & $\begin{array}{l}\text { AM } \\
\text { (\%) }\end{array}$ & $\begin{array}{l}\text { AT } \\
\text { (\%) }\end{array}$ & $\begin{array}{l}C D \\
\text { (\%) }\end{array}$ \\
\hline & $r$ & 1 & -0.43 & -0.09 & -0.17 & -0.23 & 0.003 & -0.05 & -0.01 & -0.04 & 0.05 \\
\hline \multirow[t]{3}{*}{ VOL } & $\mathbf{p}$ & & $<0.0001$ & 0.003 & $<0.0001$ & $<0.0001$ & 0.92 & 0.07 & 0.82 & 0.20 & 0.10 \\
\hline & $\mathbf{N}$ & 1,172 & 1,172 & 1,168 & 1,017 & 856 & 1,172 & 1,172 & 1,171 & 1,172 & 1,172 \\
\hline & $r$ & & 1 & 0.01 & 0.07 & 0.10 & -0.03 & 0.01 & -0.02 & 0.07 & -0.04 \\
\hline \multirow[t]{3}{*}{ CONC } & $\mathbf{p}$ & & & 0.74 & 0.02 & 0.003 & 0.25 & 0.74 & 0.58 & 0.01 & 0.23 \\
\hline & $\mathbf{N}$ & & 1,173 & 1,169 & 1,018 & 857 & 1,173 & 1,173 & 1,172 & 1,173 & 1,173 \\
\hline & $r$ & & & 1 & 0.33 & 0.36 & 0.02 & -0.06 & 0.004 & -0.05 & -0.07 \\
\hline \multirow[t]{3}{*}{ MOTUD } & $\mathbf{p}$ & & & & $<0.0001$ & $<0.0001$ & 0.47 & 0.05 & 0.89 & 0.08 & 0.01 \\
\hline & $\mathbf{N}$ & & & 1,169 & 1,018 & 856 & 1,169 & 1,169 & 1,168 & 1,169 & 1,169 \\
\hline & $\mathbf{r}$ & & & & 1 & 0.70 & -0.01 & -0.08 & 0.04 & 0.01 & -0.08 \\
\hline \multirow[t]{3}{*}{ мот1 } & $\mathbf{p}$ & & & & & $<0.0001$ & 0.75 & 0.01 & 0.26 & 0.63 & 0.01 \\
\hline & $\mathbf{N}$ & & & & 1,018 & 816 & 1,018 & 1,018 & 1,017 & 1,018 & 1,018 \\
\hline & $r$ & & & & & 1 & -0.04 & -0.10 & -0.07 & 0.02 & -0.07 \\
\hline \multirow[t]{3}{*}{ Мот2 } & $\mathbf{p}$ & & & & & & 0.19 & 0.01 & 0.04 & 0.51 & 0.04 \\
\hline & $\mathbf{N}$ & & & & & 857 & 857 & 857 & 856 & 857 & 857 \\
\hline & $r$ & & & & & & 1 & 0.08 & -0.02 & -0.03 & 0.03 \\
\hline \multirow[t]{3}{*}{$A H$} & $\mathbf{p}$ & & & & & & & 0.01 & 0.60 & 0.28 & 0.36 \\
\hline & $\mathbf{N}$ & & & & & & 1,173 & 1,173 & 1,172 & 1,173 & 1,173 \\
\hline & $\mathbf{r}$ & & & & & & & 1 & -0.01 & -0.08 & 0.12 \\
\hline \multirow[t]{3}{*}{ AA } & $\mathbf{p}$ & & & & & & & & 0.70 & 0.01 & $<0.0001$ \\
\hline & $\mathbf{N}$ & & & & & & & 1,173 & 1,172 & 1,173 & 1,173 \\
\hline & $r$ & & & & & & & & 1 & -0.01 & 0.01 \\
\hline \multirow[t]{3}{*}{ AM } & $\mathbf{p}$ & & & & & & & & & 0.64 & 0.74 \\
\hline & $\mathbf{N}$ & & & & & & & & 1,172 & 1,172 & 1,172 \\
\hline & $\mathbf{r}$ & & & & & & & & & 1 & -0.06 \\
\hline \multirow[t]{2}{*}{ AT } & $p$ & & & & & & & & & & 0.05 \\
\hline & $\mathbf{N}$ & & & & & & & & & 1,173 & 1,173 \\
\hline \multirow[t]{2}{*}{$C D$} & $\begin{array}{l}r \\
p\end{array}$ & & & & & & & & & & 1 \\
\hline & $\mathbf{N}$ & & & & & & & & & & 1,173 \\
\hline
\end{tabular}

r: correlation coefficient; $p$ : significance level; $\mathrm{N}$ : number of observations

\subsection{Sequencing and genotyping}

In total 3,256 bp of genomic sequence were obtained that represent $209 \mathrm{bp}$ of the $5^{\prime}$ UTR, $918 \mathrm{bp}$ of the exonic sequence, 1,962 bp of the intronic sequence, $34 \mathrm{bp}$ of the $3^{\prime}$ UTR and $133 \mathrm{bp}$ of the $3^{\prime}$-flanking sequence of the porcine DNAL4 gene. Twenty-three SNP were detected by comparative sequencing. Ten SNP were novel (ss1753773880- 
ss1753773888, ss1753773898), thirteen SNP were confirmed by this study as they were already available in the NCBI dbSNP database but of unpublished status (see rs numbers in Table 4). In comparison to the known reference sequence (GenBank Acc. No. AM284969.1) a monomorphic insertion (g.2674_2675insG) was determined in all examined Al boars indicating most likely a sequencing problem in the reference sequence. Twenty of the described SNP are located in intronic regions. Two are silent mutations in exon 4 and one polymorphism is located $51 \mathrm{bp}$ downstream of DNAL4. Major allele frequencies are between 0.57 (g.2960G>A) to 0.99 (g.2994T>C), but seventeen of the 23 SNP reveal minor allele frequencies of less than 0.10 . Allele and genotype frequencies are shown in Table 4.

Table 4: Genotype and allele frequencies per SNP

\begin{tabular}{|c|c|c|c|c|c|c|c|}
\hline Regions & SNP & SNP ID & Genotypes & $\mathbf{N}$ & $\begin{array}{r}\text { Genotype } \\
\text { frequencies }\end{array}$ & Alleles & $\begin{array}{r}\text { Allele } \\
\text { frequencies }\end{array}$ \\
\hline & & & GG & 71 & 0.87 & $\mathrm{G}$ & 0.92 \\
\hline & g. $817 \mathrm{G}>\mathrm{C}$ & $\underline{\text { ss1753773880 }}$ & $\mathrm{GC}$ & 9 & 0.11 & $\mathrm{C}$ & 0.08 \\
\hline & & & $\mathrm{CC}$ & 2 & 0.02 & & \\
\hline & & & TT & 71 & 0.87 & $\mathrm{~T}$ & 0.92 \\
\hline & g.818T $>C$ & ss1753773881 & TC & 9 & 0.11 & C & 0.08 \\
\hline & & & $\mathrm{CC}$ & 2 & 0.02 & & \\
\hline & & & $\mathrm{CC}$ & 61 & 0.74 & C & 0.86 \\
\hline \multirow[t]{15}{*}{ Intron 1} & g. $824 C>A$ & $\underline{\text { ss1753773898 }}$ & $\mathrm{CA}$ & 19 & 0.23 & $A$ & 0.14 \\
\hline & & & $A A$ & 2 & 0.02 & & \\
\hline & & & $\mathrm{CC}$ & 77 & 0.94 & $\mathrm{C}$ & 0.96 \\
\hline & g. $936 \mathrm{C}>\mathrm{T}$ & $\underline{\text { ss1753773882 }}$ & $\mathrm{CT}$ & 4 & 0.05 & $\mathrm{~T}$ & 0.04 \\
\hline & & & $\mathrm{TT}$ & 1 & 0.01 & & \\
\hline & & & AA & 72 & 0.88 & $A$ & 0.93 \\
\hline & g. $1007 A>G$ & ss1753773883 & $A G$ & 9 & 0.11 & G & 0.07 \\
\hline & & & GG & 1 & 0.01 & & \\
\hline & & & $\mathrm{TT}$ & 71 & 0.87 & $\mathrm{~T}$ & 0.93 \\
\hline & g.2290T>A & rs337735845 & TA & 10 & 0.12 & $A$ & 0.07 \\
\hline & & & $A A$ & 1 & 0.01 & & \\
\hline & & & GG & 77 & 0.94 & G & 0.96 \\
\hline & g.2580G $>T$ & rs340556686 & GT & 4 & 0.05 & $\mathrm{~T}$ & 0.04 \\
\hline & & & $\mathrm{TT}$ & 1 & 0.01 & & \\
\hline & & & $A A$ & 77 & 0.94 & $A$ & 0.96 \\
\hline \multirow[t]{8}{*}{ Intron 2} & g. $2613 A>G$ & rs323353426 & $A G$ & 4 & 0.05 & G & 0.04 \\
\hline & & & GG & 1 & 0.01 & & \\
\hline & & & GG & 10 & 0.12 & $\mathrm{G}$ & 0.35 \\
\hline & g. $2644 G>A$ & rs344691403 & GA & 37 & 0.45 & $A$ & 0.65 \\
\hline & & & $A A$ & 35 & 0.43 & & \\
\hline & & & $\mathrm{CC}$ & 10 & 0.12 & C & 0.33 \\
\hline & g. $2649 C>A$ & rs327688252 & $\mathrm{CA}$ & 34 & 0.41 & $A$ & 0.67 \\
\hline & & & AA & 38 & 0.46 & & \\
\hline
\end{tabular}


Continued from page 49

\begin{tabular}{|c|c|c|c|c|c|c|c|}
\hline Regions & SNP & SNP ID & Genotypes & $\mathbf{N}$ & $\begin{array}{r}\text { Genotype } \\
\text { frequencies }\end{array}$ & Alleles & $\begin{array}{r}\text { Allele } \\
\text { frequencies }\end{array}$ \\
\hline \multirow{30}{*}{ Intron 2} & \multirow{3}{*}{ g. $2654 C>T$} & \multirow{3}{*}{ rs334069472 } & $\mathrm{CC}$ & 77 & 0.94 & C & 0.96 \\
\hline & & & CT & 4 & 0.05 & $\mathrm{~T}$ & 0.04 \\
\hline & & & TT & 1 & 0.01 & & \\
\hline & \multirow{3}{*}{ g.2674_2675insG ${ }^{1}$} & \multirow{3}{*}{$\underline{\text { ss1753773884 }}$} & -- & 0 & 0.00 & - & 0.00 \\
\hline & & & $-G$ & 0 & 0.00 & G & 1.00 \\
\hline & & & GG & 82 & 1.00 & & \\
\hline & \multirow{3}{*}{ g.2693G $>A$} & \multirow{3}{*}{ rs345452401 } & GG & 77 & 0.94 & G & 0.96 \\
\hline & & & GA & 4 & 0.05 & $A$ & 0.04 \\
\hline & & & AA & 1 & 0.01 & & \\
\hline & \multirow{3}{*}{ g.2698T>C } & \multirow{3}{*}{ rs328215499 } & TT & 7 & 0.09 & $\mathrm{~T}$ & 0.30 \\
\hline & & & $\mathrm{TC}$ & 35 & 0.43 & C & 0.70 \\
\hline & & & $\mathrm{CC}$ & 40 & 0.49 & & \\
\hline & \multirow{3}{*}{ g. $2745 C>G$} & \multirow{3}{*}{ rs335765887 } & $\mathrm{CC}$ & 77 & 0.94 & C & 0.96 \\
\hline & & & CG & 4 & 0.05 & G & 0.04 \\
\hline & & & GG & 1 & 0.01 & & \\
\hline & \multirow{3}{*}{ g.2820Ainsdel } & \multirow{3}{*}{$\underline{\text { ss1753773885 }}$} & AA & 77 & 0.94 & $A$ & 0.96 \\
\hline & & & $A-$ & 4 & 0.05 & - & 0.04 \\
\hline & & & -- & 1 & 0.01 & & \\
\hline & \multirow{3}{*}{ g. $2947 T>C$} & \multirow{3}{*}{ rs33977008 } & TT & 77 & 0.94 & $\mathrm{~T}$ & 0.96 \\
\hline & & & $\mathrm{TC}$ & 4 & 0.05 & C & 0.04 \\
\hline & & & $\mathrm{CC}$ & 1 & 0.01 & & \\
\hline & \multirow{3}{*}{ g.2960G $>A$} & \multirow{3}{*}{ rs332157878 } & GG & 14 & 0.17 & G & 0.43 \\
\hline & & & $\mathrm{GA}$ & 43 & 0.52 & $A$ & 0.57 \\
\hline & & & AA & 25 & 0.30 & & \\
\hline & \multirow{3}{*}{ g.2979A>G } & \multirow{3}{*}{ rs342055920 } & $A A$ & 77 & 0.94 & $A$ & 0.96 \\
\hline & & & AG & 4 & 0.05 & G & 0.04 \\
\hline & & & GG & 1 & 0.01 & & \\
\hline & \multirow{3}{*}{ g.2994T>C } & \multirow{3}{*}{ rs334169250 } & TT & 78 & 0.99 & $\mathrm{~T}$ & 0.99 \\
\hline & & & $\mathrm{TC}$ & 0 & 0.00 & C & 0.01 \\
\hline & & & $\mathrm{CC}$ & 1 & 0.01 & & \\
\hline \multirow{6}{*}{ Exon 4} & \multirow{3}{*}{ g.5814A>G } & \multirow{3}{*}{ ss1753773887 } & AA & 73 & 0.89 & $A$ & 0.94 \\
\hline & & & AG & 8 & 0.10 & G & 0.06 \\
\hline & & & GG & 1 & 0.01 & & \\
\hline & \multirow{3}{*}{ g.6024T>C } & & TT & 57 & 0.70 & $\mathrm{~T}$ & 0.84 \\
\hline & & $\underline{\text { ss1753773888 }}$ & $\mathrm{TC}$ & 24 & 0.29 & C & 0.16 \\
\hline & & & $\mathrm{CC}$ & 1 & 0.01 & & \\
\hline & & & GG & 75 & 0.91 & G & 0.95 \\
\hline Near $\mathbf{3}^{\mathbf{2}^{2}}$ & g.6148G $>A$ & $\underline{\text { ss1753773898 }}$ & $\mathrm{GA}$ & 5 & 0.06 & $A$ & 0.05 \\
\hline & & & AA & 2 & 0.02 & & \\
\hline
\end{tabular}

SNP with rs numbers were already available on dbSNP. SNP with ss numbers were submitted by the authors.

${ }^{1}$ was excluded from statistical analysis. ${ }^{2} 51 \mathrm{bp}$ downstream of DNAL4

Linkage disequilibrium (LD) was calculated for all SNP (Figure 1). In case of a complete LD $(n=13)$ only one SNP was taken for the further statistical analyses, i.e. g.818T >C, 
g.824C >A, g.936C >T, g.1007A>G, g.2290T>A, g.2644G>A, g.2649C>A, g.2698T>C, g.2960G>A, g.2994T>C, g.5814A>G, g.6024T>C, and g.6148G >A.

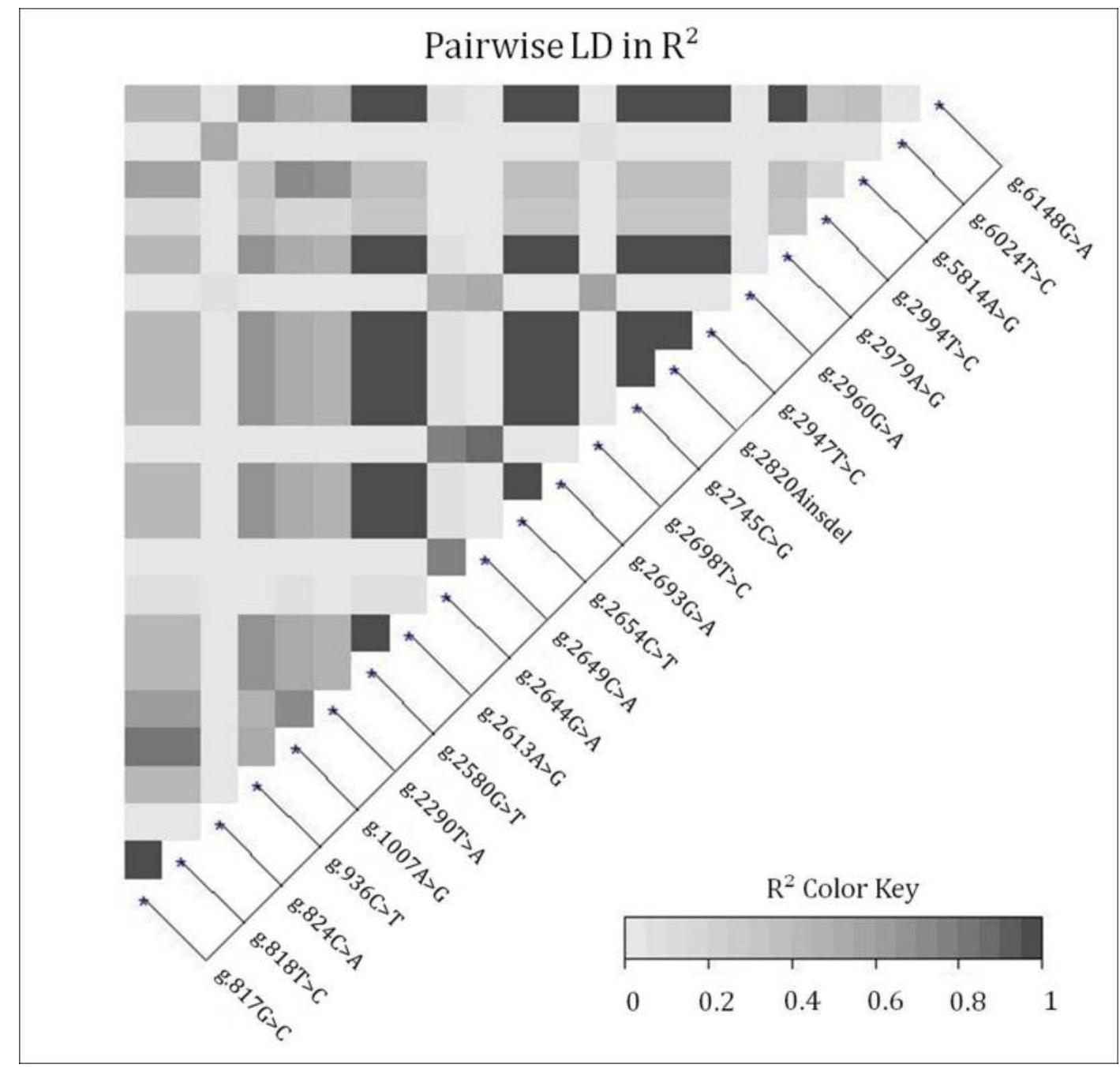

Figure 1: Pairwise linkage disequilibrium map in $\mathrm{R}^{2}$ of all detected polymorphic allelic variants $(\mathrm{n}=23)$ in porcine DNAL4.

\subsection{Association analyses}

A single marker regression (SMR) analysis adjusted for breed, season, and age at semen collection. Duration between semen collections and interactions of these parameters were considered as fixed variables, and the SNP as fixed regression term. DNAL4 polymorphisms had no significant effects on ejaculate volume $(p>0.3)$ or concentration ( $p>0.1$ ) while six of them (g.818T>C, g.936C>T, g.1007A>G, g.2290T>A, g.2994T>C, g.5814A>G) influenced sperm motility traits significantly. 
The most significant effect was detected for SNP g.1007A>G. As given in Figure 2 and Table 5, the SMR results have revealed highly a significant effect $(p<0.0001)$ of SNP g.1007A $>$ G on MOTUD with a gene substitution effect of $-4.59 \%$. Considering the SNP further as a main class factor (DRM), significant differences between the genotypes existed. Genotypic values were $67.67 \%$ for the wildtype variant AA, $64.16 \%$ for the heterozygous genotype AG, and $53.91 \%$ for the mutant GG genotype (Table 5).

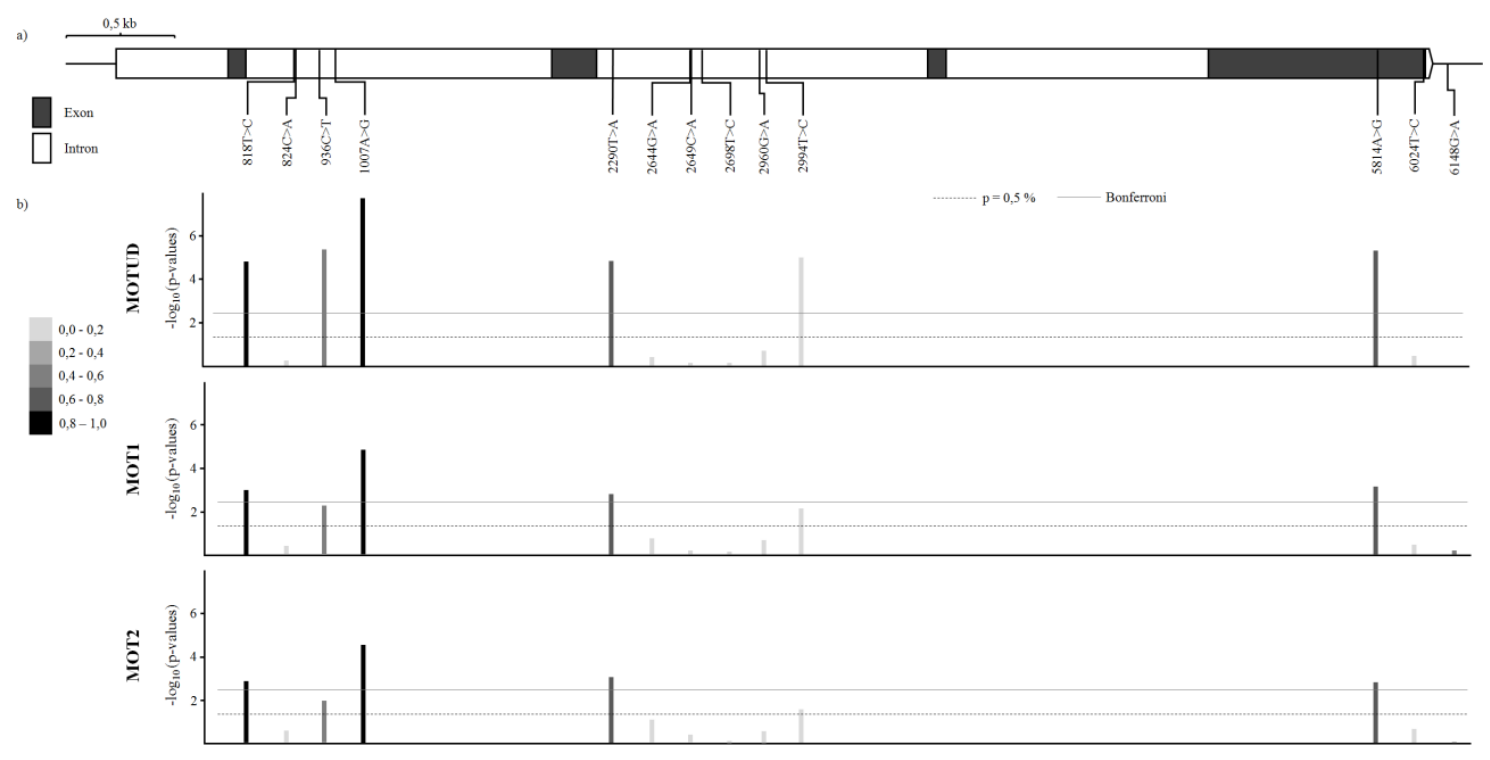

Figure 2: a) Gene structure of the porcine DNAL4 gene based on GenBank Acc. No. AM284969.1. Filled grey boxes represent exons, SNP positions are marked by thin black lines. SNP g.6148G >A is located 51 bp downstream DNAL4.

b) Influence of detected SNP on sperm motility traits (MOTUD, MOT1, MOT2) as assessed by SMR. The position of each SNP is given on porcine DNAL4, the columns show $\mathrm{R}^{2}$ values between both SNP and the most significant variant g.1007A>G.

In addition the gene substitution effect of g.1007A>G reduces MOT1 (-10.33\%) respectively MOT2 (-19.37\%; $p<0.0001)$. Furthermore significant differences between genotypes $A A$ and $A G$ as well as AA and GG for MOT1 and MOT2 existed applying the DRM model (Table 5).

Besides this, associations between SNP and sperm morphology traits AM, AA, and AT have been observed, but not for $\mathrm{AH}$ and $\mathrm{CD}$. Relationships between significant SNP and sperm morphology traits and the direction of the effect based on DRM and SMR analyses are given in Table 6. There were significant associations between five SNP 
(g.818T>C, g.1007A>G, g.2290T>A, g.2698T>C, g.5814A>G) and AM. Two variants (g.2649C $>A$ and g.5814A $>G$ ) influence $A A$, and a significant effect of g.6148G $>A$ on AT was also detected (Figure 3).

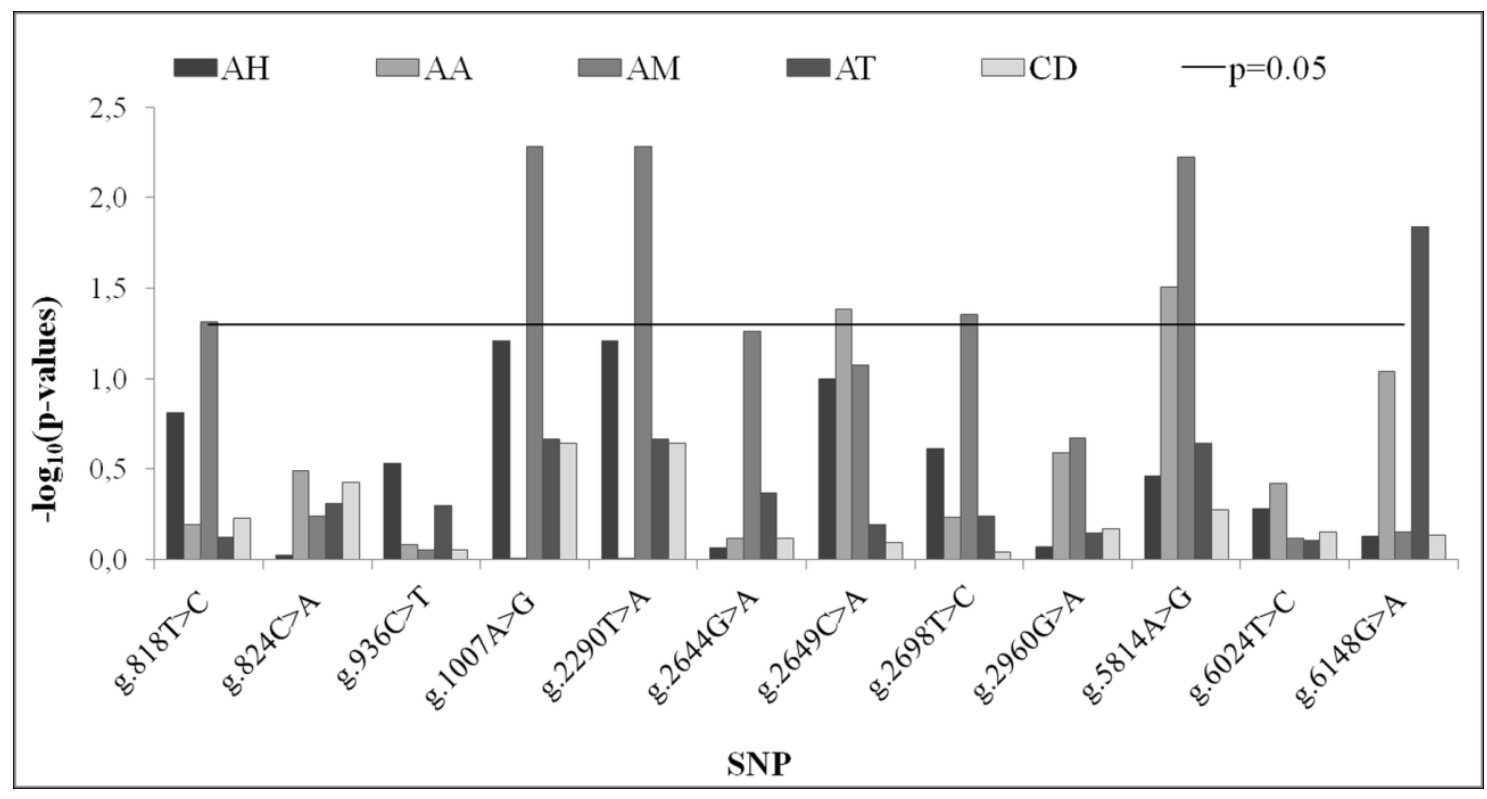

Figure 3: SNP effects on morphological parameters (AT, $A M, A H, A A$, and $C D$ ) according to SMR.

The average gene substitution effect of g.1007A $>G$ and 2290T>A on AM was e.g. $0.71 \%$. The DRM model estimated genotypic values of $0.10 \%$ for the wildtype and $0.81 \%$ for the heterozygous variant. The effects of the two SNP on the number of AM were below $1 \%$, but this observation might be biased as the mutant genotype is missing according to the low number of samples available. Variants (g.2649C>A and g.5814A $>G$ ) influence significantly the number of $A A$. g.2649C $>A$ leads to less spermatozoa with AA (SMR model). The gene substitution effect was $-1.92 \%$. Genotypic values derived from the corresponding DRM model were $9.48 \%, 4.06 \%$, and $3.63 \%$ for genotypes CC, CA and AA.

SNP g.6148G>A increases the number of AT. Genotypic values were $7.03 \%$ for the GG genotype compared to $10.94 \%$ for the heterozygous variant and $16.30 \%$ for the mutant genotype AA. Thereby the wildtype GG differs significantly from the mutant AA genotype $(p=0.03)$. Regarding the SNP as a regression term (SMR) the average gene substitution effect of g.6148G >A was $4.40 \%$. 
Table 5: Relationship between significant SNP and sperm motility traits. Slope derives from $\mathrm{SMR}^{1}$, significant differences are shown in Figure 2. Genotypic values are shown as LSmeans from $D_{R M}{ }^{2}$. Significant differences between means were tested using t-test adjusted by Bonferroni method

\begin{tabular}{|c|c|c|c|c|c|c|c|c|c|c|c|c|}
\hline \multirow[b]{2}{*}{ SNP } & \multicolumn{4}{|c|}{ MOTUD } & \multicolumn{4}{|c|}{ мот1 } & \multicolumn{4}{|c|}{ МоT2 } \\
\hline & Slope $^{1}$ & $\begin{array}{c}A A^{2,3} \\
(N)\end{array}$ & $\begin{array}{c}A B^{2,3} \\
(N)\end{array}$ & $\begin{array}{c}\mathrm{BB}^{2,3} \\
(\mathrm{~N})\end{array}$ & Slope $^{1}$ & $\begin{array}{c}A A^{2,3} \\
(N)\end{array}$ & $\begin{array}{c}A B^{2,3} \\
(N)\end{array}$ & $\begin{array}{c}\mathrm{BB}^{2,3} \\
(\mathrm{~N})\end{array}$ & Slope $^{1}$ & $\begin{array}{c}A A^{2,3} \\
(N)\end{array}$ & $\begin{array}{c}A B^{2,3} \\
(N)\end{array}$ & $\begin{array}{c}\mathrm{BB}^{2,3} \\
(\mathrm{~N})\end{array}$ \\
\hline g. $818 \mathrm{~T}>\mathrm{C}$ & -3.30 & $\begin{array}{l}67.55^{\mathrm{a}} \\
(7994)\end{array}$ & $\begin{array}{c}64.03^{b} \\
(642)\end{array}$ & $\begin{array}{c}61.38^{\mathrm{b}} \\
(126)\end{array}$ & -7.05 & $\begin{array}{l}52.77^{\mathrm{a}} \\
(6841)\end{array}$ & $\begin{array}{c}43.36^{\mathrm{ab}} \\
(453)\end{array}$ & $\begin{array}{c}43.37^{b} \\
(115)\end{array}$ & -13.43 & $\begin{array}{l}43.83^{\mathrm{a}} \\
(5337)\end{array}$ & $\begin{array}{c}24.71^{\mathrm{ab}} \\
(415)\end{array}$ & $\begin{array}{r}28.21^{b} \\
(76)\end{array}$ \\
\hline g. $936 \mathrm{C}>\mathrm{T}$ & -4.94 & $\begin{array}{l}67.53^{\mathrm{a}} \\
(8484)\end{array}$ & $\begin{array}{c}64.53^{b} \\
(262)\end{array}$ & $\begin{array}{c}54.04^{c} \\
(16)\end{array}$ & -8.67 & $\begin{array}{l}52.51^{\mathrm{a}} \\
(7202)\end{array}$ & $\begin{array}{r}47.18^{\mathrm{a}} \\
(196)\end{array}$ & $\begin{array}{c}28.58^{b} \\
(11)\end{array}$ & -15.51 & $\begin{array}{l}42.84^{\mathrm{a}} \\
(5668)\end{array}$ & $\begin{array}{c}31.14^{\mathrm{a}} \\
(143)\end{array}$ & $\begin{array}{c}5.04^{a} \\
(17)\end{array}$ \\
\hline g.1007A>G & -4.59 & $\begin{array}{l}67.67^{\mathrm{a}} \\
(8104)\end{array}$ & $\begin{array}{c}64.16^{\mathrm{b}} \\
(642)\end{array}$ & $\begin{array}{c}53.91^{\mathrm{c}} \\
(16)\end{array}$ & -10.33 & $\begin{array}{l}53.17^{\mathrm{a}} \\
(6949)\end{array}$ & $\begin{array}{r}43.75^{b} \\
(453)\end{array}$ & $\begin{array}{c}28.44^{b} \\
(11)\end{array}$ & -19.37 & $\begin{array}{l}44.12^{\mathrm{a}} \\
(5396)\end{array}$ & $\begin{array}{c}24.91^{b} \\
(415)\end{array}$ & $\begin{array}{c}4.67^{b} \\
(17)\end{array}$ \\
\hline g.2290T $>A$ & -3.68 & $\begin{array}{l}67.53^{a} \\
(8052) \\
\end{array}$ & $\begin{array}{c}65.20^{b} \\
(694)\end{array}$ & $\begin{array}{c}53.86^{\mathrm{C}} \\
(16)\end{array}$ & -7.60 & $\begin{array}{l}52.72^{\mathrm{a}} \\
(6897) \\
\end{array}$ & $\begin{array}{c}47.00^{b} \\
(501)\end{array}$ & $\begin{array}{c}28.28^{\mathrm{C}} \\
(11)\end{array}$ & -15.46 & $\begin{array}{l}43.47^{\mathrm{a}} \\
(5354)\end{array}$ & $\begin{array}{r}29.79^{\mathrm{a}} \\
(457)\end{array}$ & $\begin{array}{c}4.37^{a} \\
(17)\end{array}$ \\
\hline g.2994T>C & -6.67 & $\begin{array}{l}67.02^{\mathrm{a}} \\
(8421) \\
\end{array}$ & $\begin{array}{c}\text { N/A } \\
(0)\end{array}$ & $\begin{array}{c}53.67^{b} \\
(16)\end{array}$ & -11.85 & $\begin{array}{l}51.29^{\mathrm{a}} \\
(7181) \\
\end{array}$ & $\begin{array}{c}\mathrm{N} / \mathrm{A} \\
(0)\end{array}$ & $\begin{array}{c}27.60^{b} \\
(11)\end{array}$ & -18.70 & $\begin{array}{l}41.08^{\mathrm{a}} \\
(5618)\end{array}$ & $\begin{array}{c}\text { N/A } \\
(0)\end{array}$ & $\begin{array}{c}3.68^{b} \\
(17)\end{array}$ \\
\hline g.5814A>G & -4.09 & $\begin{array}{l}67.54^{\mathrm{a}} \\
(7995)\end{array}$ & $\begin{array}{c}64.90^{b} \\
(751)\end{array}$ & $\begin{array}{c}53.92^{\mathrm{C}} \\
(16)\end{array}$ & -8.65 & $\begin{array}{l}52.81^{a} \\
(6850)\end{array}$ & $\begin{array}{c}45.95^{\mathrm{b}} \\
(548)\end{array}$ & $\begin{array}{c}28.46^{\mathrm{b}} \\
(11)\end{array}$ & -15.78 & $\begin{array}{l}43.35^{\mathrm{a}} \\
(5309)\end{array}$ & $\begin{array}{c}29.51^{\mathrm{a}} \\
(502)\end{array}$ & $\begin{array}{c}4.69^{\mathrm{a}} \\
(17)\end{array}$ \\
\hline
\end{tabular}

${ }^{1}$ : Single Marker Regression; ${ }^{2}$ : Dominant-Recessive Model; ${ }^{3}$ : Note AA, BB, and AB represent generally the two homozygous and the heterozygous genotype per SNP. For the actual genotypes refer to Table 4. 
Table 6: Relationships between significant SNP and sperm morphology traits.

\begin{tabular}{|c|c|c|c|c|c|c|c|c|c|c|c|c|c|c|c|c|c|c|c|c|}
\hline & \multicolumn{4}{|c|}{ Abnormal head } & \multicolumn{4}{|c|}{ Abnormal acrosome } & \multicolumn{4}{|c|}{ Abnormal midpiece } & \multicolumn{4}{|c|}{ Abnormal tail } & \multicolumn{4}{|c|}{ Cytoplasmic droplet } \\
\hline & Slope & AA & $A B$ & BB & Slope & AA & $A B$ & BB & Slope & AA & $A B$ & BB & Slope & AA & $A B$ & BB & Slope & AA & $A B$ & BB \\
\hline g. $818 \mathrm{~T}>\mathrm{C}$ & 0.58 & $1.18^{\mathrm{a}}$ & $2.62^{\mathrm{a}}$ & $1.87^{\mathrm{a}}$ & -0.66 & $4.41^{\mathrm{a}}$ & $4.16^{\mathrm{a}}$ & $1.79^{\mathrm{a}}$ & 0.48 & $0.09^{\mathrm{a}}$ & $0.81^{b}$ & $0.14^{\mathrm{ab}}$ & 0.57 & $7.57^{\mathrm{a}}$ & $10.25^{\mathrm{a}}$ & $2.18^{\mathrm{a}}$ & 0.53 & $4.34^{\mathrm{a}}$ & $6.06^{a}$ & $1.48^{\mathrm{a}}$ \\
\hline g.1007A>G & 0.84 & $1.78^{\mathrm{a}}$ & $2.62^{\mathrm{a}}$ & N/A & -0.20 & $4.37^{\mathrm{a}}$ & $4.16^{\mathrm{a}}$ & N/A & 0.71 & $0.10^{\mathrm{a}}$ & $0.81^{b}$ & N/A & 2.79 & $7.52^{\mathrm{a}}$ & $10.31^{\mathrm{a}}$ & N/A & 1.78 & $4.29^{\mathrm{a}}$ & $6.06^{a}$ & N/A \\
\hline g.2290T>A & 0.84 & $178^{\mathrm{a}}$ & $262^{a}$ & N/A & -0.20 & $4.37^{\mathrm{a}}$ & $4.16^{\mathrm{a}}$ & N/A & 0.71 & $0.10^{\mathrm{a}}$ & $0.81^{b}$ & N/A & 2.79 & $7.52^{\mathrm{a}}$ & $10.31^{\mathrm{a}}$ & N/A & 1.78 & $4.29^{\mathrm{a}}$ & $6.06^{\mathrm{a}}$ & $\mathrm{N} / \mathrm{A}$ \\
\hline g. $2644 G>A$ & 0.03 & $2.17^{\mathrm{a}}$ & $1.80^{\mathrm{a}}$ & $1.94^{\mathrm{a}}$ & 0.07 & $5.18^{\mathrm{a}}$ & $4.06^{\mathrm{a}}$ & $4.54^{a}$ & -0.28 & $1.33^{\mathrm{a}}$ & $0.09^{b}$ & $0.10^{b}$ & 0.95 & $9.71^{\mathrm{a}}$ & $6.67^{\mathrm{a}}$ & $8.99^{\mathrm{a}}$ & 0.07 & $5.18^{\mathrm{a}}$ & $4.06^{a}$ & $4.54^{\mathrm{a}}$ \\
\hline g. $2649 C>A$ & 0.35 & $1.78^{\mathrm{a}}$ & $1.61^{\mathrm{a}}$ & $2.17^{\mathrm{a}}$ & -1.92 & $9.48^{a}$ & $4.06^{b}$ & $3.63^{b}$ & -0.23 & $0.99^{\mathrm{a}}$ & $0.06^{b}$ & $0.13^{b}$ & 0.53 & $8.46^{\mathrm{a}}$ & $7.09^{\mathrm{a}}$ & $8.46^{a}$ & 0.12 & $6.57^{\mathrm{a}}$ & $3.53^{a}$ & $5.01^{\mathrm{a}}$ \\
\hline g.2698T $>C$ & 0.27 & $2.17^{\mathrm{a}}$ & $1.64^{\mathrm{a}}$ & $2.09^{\mathrm{a}}$ & 0.03 & $4.47^{\mathrm{a}}$ & $4.11^{\mathrm{a}}$ & $4.54^{\mathrm{a}}$ & -0.29 & $1.62^{\mathrm{a}}$ & $0.06^{b}$ & $0.12^{b}$ & 0.70 & $9.29^{\mathrm{a}}$ & $6.98^{\mathrm{a}}$ & $8.52^{\mathrm{a}}$ & -0.05 & $7.54^{\mathrm{a}}$ & $3.85^{\mathrm{a}}$ & $4.80^{\mathrm{a}}$ \\
\hline g. $5814 A>G$ & 0.44 & $1.82^{\mathrm{a}}$ & $2.26^{\mathrm{a}}$ & N/A & 3.22 & $3.93^{a}$ & $7.15^{\mathrm{b}}$ & N/A & 0.70 & $0.09^{\mathrm{a}}$ & $0.78^{b}$ & N/A & 2.70 & $7.51^{\mathrm{a}}$ & $10.20^{\mathrm{a}}$ & N/A & 0.64 & $4.42^{\mathrm{a}}$ & $5.07^{\mathrm{a}}$ & N/A \\
\hline g. $6148 \mathrm{G}>\mathrm{A}$ & -0.19 & $1.90^{\mathrm{a}}$ & $1.84^{\mathrm{a}}$ & $1.29^{\mathrm{a}}$ & 1.62 & $3.96^{\mathrm{a}}$ & $1.17^{\mathrm{b}}$ & $2.21^{a}$ & -0.13 & $0.20^{\mathrm{a}}$ & $0.00^{\mathrm{a}}$ & $0.03^{a}$ & 4.40 & $7.03^{\mathrm{a}}$ & $10.94^{\mathrm{ab}}$ & $16.30^{b}$ & -0.98 & $4.68^{a}$ & $2.14^{\mathrm{a}}$ & $4.01^{a}$ \\
\hline
\end{tabular}

Genotypic values are shown as LSmeans using DRM. Slopes derive from SMR for gene substitution model. Significant differences for slopes are given in Figure 3. Parameter estimates were derived from GLM with identity link function. Note $A A, B B$ and $A B$ represent generally the two homozygous and the heterozygous genotype per SNP. For the actual genotypes refer to Table 4. 


\section{Discussion}

The ejaculates in our investigation met the requirements of the umbrella organisation of organised pig production in Germany (Zentralverband der Deutschen Schweineproduktion; ZDS 2015). There are, however, remarkable differences compared to the recent study by McPherson et al. (2014). These authors reported AM as the most commonly defect of the boar sperm cells $(8.8 \% \pm 10.6$ vs. $0.18 \% \pm 1.85)$, followed by $\mathrm{AH}(7.7 \% \pm 6.0$ vs. $2.01 \% \pm 4.28)$. The occurrence of $\mathrm{CD}$ was $4.3 \%$ (distal) respectively $2.4 \%$ (proximal) and at the same range like in our study $(3.79 \% \pm 8.15)$. We report a six-fold difference for a deficient AA $(4.52 \% \pm 6.95$ compared to $0.7 \% \pm 1.2)$, and the percentage of AT was much higher in our investigation $(7.88 \% \pm 9.92)$ compared to $2.2 \% \pm 4.1$.

The estimation of associations between different sperm parameters revealed negative phenotypic correlation between VOL and CONC. Earlier, also negative - but higher correlations between these traits have been proposed by e.g. Smital et al. (2005) $(r=-0.61)$, Wolf (2009) $(r=-0.71)$, and Wolf \& Smital (2009) $(r=-0.73)$ in Czech Landrace and Czech Large White. Assuming a genetic determination of the traits as proposed by heritabilities of 0.18 for concentration and 0.24 for VOL (Wolf \& Smital, 2009), the above mentioned correlations imply that putatively causative genetic variants will have mutual, but antagonistic, effects on these observed parameters.

Furthermore we observed significantly negative phenotypic correlation between VOL and the three motility traits. Contrary to that progressive motilities after storage were positively correlated with higher CONC of the native ejaculate. In addition positive relationships have been determined between the three motilities. The correlations indicate that the motility of stored sperm cells has decreased during storage, but the evaluated positive correlations between MOT1 and MOT2 underline that boar semen can be stored for at least two days without losing its progressive motility dramatically.

A study on sperm dysfunction and male infertility by Abu et al. (2012) did not claim a correlation between normal sperm morphology and motility $(r=0.0653, p=0.5361$, $\mathrm{n}=92$ ). In another study Caskurlu et al. (1999) determined, however, a negative correlation between immature germ cells and motility in human semen samples. The pres- 
ence of a CD is a characteristic of an immature spermatozoa (Bonet, 1990). Our results support this hypothesis.

SNP data were created for 82 boars by Sanger sequencing and in one case by a RFLP. That approach allowed to check manually the identity of each detected variation per boar and helped - in comparison to studies using SNP chips - to accurately avoid errors and inconsistencies at time of allele calling. Drawbacks of the study are, however, seemingly e.g. genotype classes of limited size or even classes that are absent due to low allele frequencies. Yet the data were obtained from boars of an artificial insemination station postulating that animals with an enduring poor semen quality are generally rare. Moreover, alleles at low frequencies are supposedly the consequence of this intensified selection pressure. Thus, we explicitly considered genetic variations at low frequencies in our study. We hypothesize that these SNP in such a population of boars are helpful to assess associations with reduced qualitative and morphological spermatological parameters. The most significant effect of a SNP influencing sperm motility traits was detected for SNP g.1007A>G located in intron 2 of DNAL4. We also observed highly significant effects on all motility traits resulting in a marked reduction as a consequence of gene substitution. Furthermore significant differences between genotypes $A A$ and $A G$ as well as $A A$ and GG for MOT1 and MOT2 have existed. Although it is about a silent mutation, other studies have demonstrably shown that such SNPs can nevertheless have e.g. effects on RNA stability (Capon et al., 2004) or protein folding (Kimchi-Sarfaty et al., 2007). In addition, the data imply a dominance effect of the A-allele on motility traits, suggesting that it plays a role during the formation of the sperm midpiece and is important for sperm function. That might lead to a loss of flagellar and ciliary motility which are driven by the activity of dynein, which produces microtubule sliding within the axonemes (Shingyoji, 2013). Furthermore, the data indicate effects of SNP g.1007A $>$ G on the three motility traits and the trait AM. This is in contrast to other studies that have claimed associations between SNP on both motility and plasma droplet rate at the same time, i.e. SNP g.672C $>$ T in ESR1 (Gunawan et al. 2011), SNP g.35547A>G) in ESR2 (Gunawan et al., 2012), SNP g.358A>T in the CD9 gene (Kaewmala et al., 2011). Further, Lin et al. (2006) postulated significant associations of the porcine GNRHR. The variants affected also the trait abnormal sperm rate. Since the 
flagellar movement depends on the axoneme that is subjected to different regulatory systems in the midpiece and principal piece of a sperm's tail (Harris et al., 2007), a polymorphism influencing motility might also affect midpiece defects. Given that the midpiece contains the mitochondria which power sperm movements, a larger midpiece may also be adaptive in terms of increased mitochondrial loading and sperm motility (Anderson et al., 2005). In spite of everything, considering the constraints of the study, g.1007A> G could just be an indirect marker that regulates the linked causative gene, for example by altering its promoter activity (Eiberg et al., 2008).

Our approach was to name only the most devastating morphological failure as trait for the analysis. As the percentage of CD was considered as the least important morphological malformation, the lack of association between a SNP within DNAL4 and both motility traits and percentage of $C D$ rate might also be a result of this hierarchy.

Uhlmann et al. (2007) described the genomic organization and sequence of the porcine DNAL4 and reported five SNP. All of them were located in non-coding regions. Further studies - including this one - revealed that DNAL4 is a highly polymorphic gene. We succeeded to confirm 13 of the 28 documented SNP and to report 10 novel ones considering different breeds and lines within breeds. Taking all documented SNP together, the potential of DNAL4 to be used in association analysis - as proposed by Uhlmann et al. (2007) - is illustrated. The reported association analysis supports the importance of DNAL4 as a candidate gene or as an indirect marker for motility traits and also midpiece defects of sperm cells. Considering also the effects of SNP (g.358A $>$ T) within the CD9 gene on sperm motility, plasma droplet rate, and abnormal spermatozoa rate (Kaewmala et al., 2011), there are some indications that regions on SSC5 are associated with male fertility. 


\section{Acknowledgements}

The study was financially supported by initial fundings provided by the University of Goettingen to CK. The authors are deeply indebted to Manfred Vopel, Dirk Teuteberg and Andrea Hartmann for animal care taking, sperm collection, and evaluation of quantitative and qualitative sperm parameters. A special thanks goes to the sequencing laboratory at the Institute of Veterinary Medicine of the University of Goettingen.

\section{Author Contributions}

CK designed the study; AM and IW performed molecular genetic analyses; SJ recorded and analysed morphological traits; RS and IW analysed the data; CK, IW and RS drafted and edited the manuscript. All authors read and approved the final manuscript

\section{Conflict of interest}

The authors declare that they do not have any financial and personal relationships with other people or organizations that could inappropriately bias or influence their work.

\section{References}

Anderson, M. J., Nyholt, J. \& Dixson, A. F. (2005). Sperm competition and the evolution of sperm midpiece volume in mammals. Journal of Zoology, 267(2), 135-142.

Bonet, S. (1990). Immature and abberant spermatozoa in the ejaculate of Sus domesticus. Animal Reproduction Science, 22, 67-80.

Bonet, S., Casas, I., Holt, W. V. \& Yeste, M. (2013). Boar Reproduction: Fundamentals and New Biotechnological Trends (Vol. 1). Heidelberg: Springer-Verlag. 
Briz, M. D., Bonet, S., Pinart, B., Egozcue, J. \& Camps, R. (1995). Comparative study of boar sperm coming from the caput, corpus, and cauda regions of the epididymis. Journal of Andrology, 16(2), 175-188.

Capon, F., Allen, M. H., Ameen, M., Burden, A. D., Tillman, D., Barker, J. N. \& Trembath, R. C. (2004). A synonymous SNP of the corneodesmosin gene leads to increased mRNA stability and demonstrates association with psoriasis across diverse ethnic groups. Human Molecular Genetics, 13(20), 2361-2368.

Caskurlu, T., Tasci, A. I., Samasti, M., Bayraktar, Z., Cek, M. \& Sevin, G. (1999). Immature germ cells in semen and their correlations with other semen parameters. International Urology Nephrology, 31(3), 389-393.

Christensen, P., Knudsen, D. B., Wachmann, H. \& Madsen, M. T. (2004). Quality control in boar semen production by use of the FACSCount AF system. Theriogenology, 62(7), 1218-1228.

Eiberg, H., Troelsen, J., Nielsen, M., Mikkelsen, A., Mengel-From, J., Kjaer, K. W. \& Hansen, L. (2008). Blue eye color in humans may be caused by a perfectly associated founder mutation in a regulatory element located within the HERC2 gene inhibiting OCA2 expression. Human Genetics, 123(2), 177-187.

Einarsson, S., Brandt, Y., Lundeheim, N. \& Madej, A. (2008). Stress and its influence on reproduction in pigs: a review. Acta Veterinaria Scandinavia, 50, 48.

Gunawan, A., Cinar, M. U., Uddin, M. J., Kaewmala, K., Tesfaye, D., Phatsara, C., Tholen, E., Looft, C. \& Schellander, K. (2012). Investigation on association and expression of ESR2 as a candidate gene for boar sperm quality and fertility. Reproduction in Domestic Animals, 47(5), 782-790.

Gunawan, A., Kaewmala, K., Uddin, M. J., Cinar, M. U., Tesfaye, D., Phatsara, C., Tholen, E., Looft, C. \& Schellander, K. (2011). Association study and expression analysis of porcine ESR1 as a candidate gene for boar fertility and sperm quality. Animal Reproduction Science, 128(1-4), 11-21.

Haidl, G., Becker, A. \& Henkel, R. (1991). Poor development of outer dense fibers as a major cause of tail abnormalities in the spermatozoa of asthenoteratozoospermic men. Human Reproduction, 6(10), 1431-1438.

Harris, T., Marquez, B., Suarez, S. \& Schimenti, J. (2007). Sperm motility defects and infertility in male mice with a mutation in Nsun7, a member of the Sun domaincontaining family of putative RNA methyltransferases. Biology of Reproduction, 77(2), 376-382.

Jung, M., Rudiger, K. \& Schulze, M. (2015). In Vitro Measures for Assessing Boar Semen Fertility. Reproduction in Domestic Animals, 50 Suppl 2, 20-24.

Kaewmala, K., Uddin, M. J., Cinar, M. U., Grosse-Brinkhaus, C., Jonas, E., Tesfaye, D., Phatsara, C., Tholen, E., Looft, C. \& Schellander, K. (2011). Association study and expression analysis of CD9 as candidate gene for boar sperm quality and fertility traits. Animal Reproduction Science, 125(1-4), 170-179.

Kimchi-Sarfaty, C., Oh, J. M., Kim, I. W., Sauna, Z. E., Calcagno, A. M., Ambudkar, S. V. \& Gottesman, M. M. (2007). A "silent" polymorphism in the MDR1 gene changes substrate specificity. Science, 315(5811), 525-528.

Lin, C. L., Ponsuksili, S., Tholen, E., Jennen, D. G., Schellander, K. \& Wimmers, K. (2006). Candidate gene markers for sperm quality and fertility of boar. Animal Reproduction Science, 92(3-4), 349-363. 
Love, C. C. (2011). Relationship between sperm motility, morphology and the fertility of stallions. Theriogenology, 76(3), 547-557.

McPherson, F. J., Nielsen, S. G. \& Chenoweth, P. J. (2014). Semen effects on insemination outcomes in sows. Animal Reproduction Science, 151(1-2), 28-33.

Miller, S. A., Dykes, D. D. \& Polesky, H. F. (1988). A simple salting out procedure for extracting DNA from human nucleated cells. Nucleic Acids Research, 16(3), 1215.

Paufler, S. K. (1974). Die künstliche Besamung beim Schwein. In S. K. Paufler (Ed.), Künstliche Besamung und Eitransplantation bei Tier und Mensch. Hannover: M. \& H. Schaper.

Sale, W. S. \& Satir, P. (1977). Direction of active sliding of microtubules in Tetrahymena cilia. Proceedings of the National Academy of Sciences USA, 74(5), 2045-2049.

Shingyoji, C. (2013). Measuring the regulation of dynein activity during flagellar motility. Methods in Enzymology, 524, 147-169.

Silverberg, K. M. \& Turner, T. (2008). Evaluation of sperm. In D. K. Gardner, A. Weissman \& C. M. Howles (Eds.), Textbook of assisted reproductive techniques (3rd Edition ed.). Zug: Informa Healthcare.

Smital, J. (2009). Effects influencing boar semen. Animal Reproduction Science, 110(34), 335-346.

Smital, J., Wolf, J. \& De Sousa, L. L. (2005). Estimation of genetic parameters of semen characteristics and reproductive traits in Al boars. Animal Reproduction Science, 86(1-2), 119-130.

Tardif, S., Laforest, J. P., Cormier, N. \& Bailey, J. L. (1999). The importance of porcine sperm parameters on fertility in vivo. Theriogenology, 52(3), 447-459.

Uhlmann, B., Kuiper, H., Distl, O. \& Leeb, T. (2007). Molecular characterization of the porcine DNAL4 gene. Archiv für Tierzucht Dummerstorf, 50(3), 267-272.

Wolf, J. (2009). Genetic parameters for semen traits in Al boars estimated from data on individual ejaculates. Reproduction in Domestic Animals, 44(2), 338-344.

Wolf, J. (2010). Heritabilities and genetic correlations for litter size and semen traits in Czech Large White and Landrace pigs. Journal of Animal Science 88(9), 28932903.

Wolf, J. \& Smital, J. (2009). Effects in genetic evaluation for semen traits in Czech Large White and Czech Landrace boars. Czech Journal of Animal Science, 54(8), 349358.

Xing, Y., Ren, J., Ren, D., Guo, Y., Wu, Y., Yang, G., Mao, H., Brenig, B. \& Huang, L. (2009). A whole genome scanning for quantitative trait loci on traits related to sperm quality and ejaculation in pigs. Animal Reproduction Science, 114(1-3), 210-218.

Xu, X., Pommier, S., Arbov, T., Hutchings, B., Sotto, W. \& Foxcroft, G. R. (1998). In vitro maturation and fertilization techniques for assessment of semen quality and boar fertility. Journal of Animal Science, 76(12), 3079-3089.

Xue, J., Dial, G. D., Trigg, T., Davies, P. \& King, V. L. (1998). Influence of mating frequency on sow reproductive performance. Journal of Animal Science, 76(12), 2962-2966.

Yubero, N., Jimenez-Marin, A., Yerle, M., Morera, L., Barbancho, M. J., Llanes, D. \& Garrido, J. J. (2003). Molecular cloning, expression pattern and chromosomal mapping of pig CD9 antigen. Cytogenetic Genome Research, 101(2), 143-146. 


\subsection{Diskussion}

Eine grundlegende Voraussetzung für die Sicherstellung eines hohen Reproduktionserfolges in der Schweinezucht ist die kontinuierliche Überprüfung der Spermaqualität und -quantität. Die Vorgaben hierfür werden in Deutschland vom ZDS festgelegt. Der zulässige Gesamtanteil morphologisch veränderter Spermien liegt in Deutschland, wie auch in der Tschechischen Republik (Lipenský et al., 2010), bei $\leq 25 \%$. Bonet (1990) fand in seiner Untersuchung $15 \%$ abnormale Spermien.

In den vorliegenden Studien konnten 78 \% der Ejakulate die gegebenen Mindestanforderungen erfüllen (Jansen et al., 2017). Am häufigsten traten dabei Schwanzfehler auf $(7,88 \%)$, gefolgt von Veränderungen des Akrosoms (4,52 \%) und Cytoplasmatropfen (3,79 \%). Im Gegensatz dazu berichten McPherson et al. (2014) von veränderten Halsmittelstücken als häufigste Anomalie in Eberejakulaten ( $8,8 \% \pm 10,6$ vs. $0,18 \% \pm 1,85)$, gefolgt von Kopfveränderungen $(7,7 \% \pm 6,0$ vs. $2,01 \% \pm 4,28)$. Cytoplasmatropfen traten in jener Studie in 4,3\% (distal) bzw. 2,4 \% (proximal) der Fälle auf. Im Mittel wiesen sie gleiche Zahlen, wie die der vorliegenden Studien auf (Wiedemann et al., 2018a). Wiesen einzelne Spermien mehr als eine morphologische Veränderung auf, wurde nur die schwerwiegendste erfasst. Die hierarchische Abstufung ist dabei Halsbrüche - Kopfkappenschäden - Kopfdeformationen - Schwanzveränderungen. Aus der Literatur ist bekannt, dass ein Vorkommen morphologisch veränderter Spermien durch die Rasse beeinflusst werden kann (Buder, 2013). Hier konnte hinsichtlich des Auftretens von Plasmatropfen ein leichter Rasseeffekt nachgewiesen werden. Eber der Deutschen Landrasse (DL) zeigten einen signifikant niedrigeren Anteil von Spermien mit Plasmatropfen im Vergleich zu Deutschen Edelschweinen (DE) (Jansen et al., 2017).

Ein deutlicherer Effekt konnte in Bezug auf die Zuchtsaison gezeigt werden. Das in der Literatur beschriebene signifikant häufigere Auftreten von morphologischen Veränderungen im Sommer (Dörner \& Hühn, 1991) konnte in den vorliegenden Untersuchungen nicht nachgewiesen werden. Das Auftreten von Kopffehlern war dennoch im Herbst signifikant verringert. Weiterhin bestätigen die vorliegenden Ergebnisse die Studie von Borg et al. (1993), mit einem signifikant höheren Vorkommen von Schwanzfehlern im Herbst. Temperaturen von über $35{ }^{\circ} \mathrm{C}$ führen vermehrt zu morphologisch veränderten Spermien, die dann aufgrund der 14-tägigen Nebenhodenpassage, erst 
zwei bis sechs Wochen später im Ejakulat sichtbar sind (Knox, 2003). Veränderungen der Kopfkappe traten im Frühling signifikant häufiger auf, als im Sommer oder Herbst. Normalerweise sind niedrige Temperaturen kein Problem für Besamungseber, da eine höhere Wärmeproduktion durch vermehrte Futteraufnahme reguliert werden kann, solange die Temperaturen nicht unter $-10{ }^{\circ} \mathrm{C}$ sinken (Knox, 2003). Um den Temperatureinfluss noch besser beurteilen zu können, wäre eine Betrachtung der morphologischen Veränderungen nach bestimmten Wetterextremen sinnvoll. Die Wetteraufzeichnungen aus Göttingen zeigen seit 2001 verschiedene Extremwerte, die möglicherweise die Spermaqualität beeinflusst haben könnten. Beispielsweise lagen die Temperaturen vom 09. bis 30. Juli 2006 durchgehend über $25^{\circ} \mathrm{C}$. Die niedrigste Temperatur wurde am 07. Januar 2009 mit $-20,2{ }^{\circ} \mathrm{C}$ gemessen, außerdem gab es in der Zeit vom 25. Dezember 2008 bis zum 17. Januar 2009 täglich Frost (Wetterstation Göttingen, 2001-2017). Daher wäre davon auszugehen, dass speziell im Spätsommer 2006 und Frühjahr 2009 mehr morphologisch veränderte Spermien auftraten. Weiler et al. (1996) determinierten die Veränderung der Tageslichtlänge als Hauptgrund für die jahreszeitlichen Schwankungen der Hodenfunktion und damit einhergehend der Testosteronproduktion. Sancho et al. (2004) bestätigen diese Ergebnisse.

Weiterhin zeigen die vorliegenden Ergebnisse einen deutlichen Effekt des Alters in Bezug auf Spermien mit Kopffehlern, Schwanzfehlern oder Plasmatropfen. Spermien mit Schwanzveränderungen nehmen mit steigendem Alter der Eber am stärksten zu. Einen altersbedingten Anstieg von Spermien mit veränderten Kopfkappen konnte nur bedingt festgestellt werden. Zwar konnten bei Ebern im Alter von 3 - 4,5 Jahren signifikant mehr Akrosomenveränderungen verzeichnet werden, als bei jüngeren Ebern. Ein weiterer altersbedingter Anstieg im Vergleich zu Ebern $>4,5$ Jahre konnte jedoch nicht nachgewiesen werden (Jansen et al., 2017). Damit decken sich die Ergebnisse nur bedingt mit denen von Čeřovský et al. (2005).

Einzelne spermatologische Parameter sind miteinander korreliert. Beispielsweise zeigen die Daten negative Korrelationen zwischen dem Ejakulatvolumen und der Spermiendichte, wie bereits von Smital et al. (2005) und Wolf \& Smital (2009) beschrieben. Die Korrelation zwischen Spermienmotilität und morphologischen Veränderungen ist kontrovers diskutiert. Abu Hassan Abu et al. (2012) konnten keinen Zusam- 
menhang nachweisen. Im Gegensatz dazu zeigten Caşkurlu et al. (1999) eine negative Korrelation zwischen Motilitätsparametern und unreifen Spermien. Da diese beispielsweise durch das Vorhandensein von Plasmatropfen gekennzeichnet sind (Bonet, 1990), können diese Ergebnisse in der Tendenz bestätigt werden. Zudem ist das Volumen negativ mit der Spermienmotilität korreliert. Die Spermienmotilitäten zu unterschiedlichen Untersuchungszeitpunkten (direkt nach der Entsamung (MOTUD)), nach 24 Std. Lagerung (MOT1) und nach 48 Std. Lagerung (MOT2)) sind ebenfalls positiv miteinander korreliert. Sowohl äußere Einflüsse, als auch genetische Faktoren (Wolf, 2009) können die Spermaqualität beeinflussen. Die vorliegenden Ergebnisse zeigen hinsichtlich der ermittelten Zuchtwerte für das Merkmal "Inzidenz der auftretenden Anomalien" populationsübergreifend einen deutlichen Effekt des einzelnen Ebers auf das Auftreten pathomorpher Spermien. Das verdeutlicht die Erblichkeit von morphologischen Spermienanonmalien und damit einen klaren genetischen Einfluss auf die Spermaqualität (Jansen et al., 2017).

Eine der Haupteinschränkungen, um Fruchtbarkeits- und Spermaqualitätsmerkmale in Zuchtprogramme zu integrieren ist, dass sie erst nach der Pubertät bestimmt werden können. Außerdem ist die Spermaqualität von unter acht Monate alten Ebern schlechter, als die älterer Tiere. Daraus ergibt sich eine achtmonatige Wartezeit bis zur Selektion, wodurch das Generationsintervall verlängert wird (Lopez Rodriguez et al., 2017). Allerdings konnten mehrere Studien moderate Heritabilitäten für Spermaqualitätsparameter nachweisen. Die Erblichkeit für die Gesamtspermienzahl eines Ejakulats liegt zwischen 0,27 und 0,48 (Smital et al., 2005; Oh et al., 2006). Für den Anteil morphologisch veränderter Spermien $\left(h^{2}=0,34\right)$, die Vorwärtsbeweglichkeit $\left(h^{2}=0,38\right)$ und die Spermienkonzentration $\left(h^{2}=0,49\right)$ können ähnliche Größenordnungen angenommen werden. Die Erblichkeit des Ejakulatvolumens $\left(h^{2}=0,58\right)$ ist noch höher (Smital et al., 2005). Unter Annahme der Heritabilitäten, die in der Literatur für Spermaqualitätsparameter beschrieben wurden, deuten die oben genannten Korrelationen darauf hin, dass ursächliche genetische Varianten antagonistische Effekte auf diese Parameter haben.

Mit Hilfe der genomischen Zuchtwertschätzung (gZWS) wäre es möglich, die Eber ohne eigene phänotypische Daten (z. B. Spermaqualitätsparameter) zu selektieren, sodass 
die Zuchtwertschätzung bereits sehr früh im Leben, z. B. direkt nach der Geburt, erfolgen könnte (Boichard et al., 2016). Dadurch könnte das Generationsintervall verkürzt werden. Allerdings wird dies stark durch die Populationsstruktur, das Merkmal (und seine Heritabilität) und durch die Typisierungsstrategie beeinflusst (Samore \& Fontanesi, 2016). Diese wiederum hat einen direkten Effekt auf die Genauigkeit der gZWS. Ein Nachteil ist jedoch, dass für Merkmale mit niedriger Heritabilität große Referenzstichproben benötigt werden. Die Genauigkeit der genetischen Beurteilung von Schweinen ist bei Merkmalen mit niedriger Heritabilität (wie Fruchtbarkeit, Wurfgröße oder Ferkelmortalität), wenigen phänotypischen Daten oder Fleischqualitätsmerkmalen relativ gering (Samore \& Fontanesi, 2016). Aus den Simulationen von Meuwissen (2009) geht hervor, dass eine Genauigkeit der Zuchtwertschätzung von lediglich 0,3 bei einer Referenzpopulation von 2.000 - 5.000 Tieren erzielt werden kann (Samore \& Fontanesi, 2016). Auch wenn HD SNP Panels für das Schwein verfügbar sind (Illumina PorcineSNP60), sind dadurch die Kosten der genomischen Selektion sehr hoch und ihre Implementierung beim Schwein dementsprechend noch sehr begrenzt. Allerdings zeigten Simulationen, dass auch mit deutlich weniger genetischen Markern (low density SNP Panels) etwa 95 \% der Genauigkeit von HD Panels erzielt werden können, wodurch außerdem die Kosten der gZWS sinken würden (Zhang et al., 2011; Samore \& Fontanesi, 2016).

An dieser Stelle können molekulargenetische Informationen verwendet werden, um die Selektion auf Fertilitätsmerkmale bei Ebern zu verbessern und diese früher im Leben zu bewerten (Kaewmala et al., 2011). Beispielsweise wurde bei finnischen Yorkshire Ebern angenommen, dass es eine genetische Ursache für einen Spermatogenese-Arrest oder das Auftreten von morphologischen Veränderungen, wie Kopfkappenfehler oder rudimentäre Schwänze, gibt. In verschiedenen Untersuchungen war es möglich, Kandidatengene für die Defekte zu identifizieren (Sironen et al., 2002; Sironen et al., 2010; Sironen et al., 2011). Weiterhin wurden Assoziationen zwischen Mikrosatelliten Markern und Spermienmotilität in QTL-Studien untersucht (Xing et al., 2009). Ein QTL für Spermienmotilität, das Vorhandensein von Cytoplasmatropfen und den Anteil morphologischer Spermien wurde im porzinen CD9-Gen (SSC5q25) ermittelt (Kaewmala et al., 2011). Ein weiteres sowohl funktionelles, als auch positionelles Kan- 
didatengen für Spermaqualität beim Schwein ist das DNAL4-Gen auf SSC5p15. Dieses kodiert für eine leichte Kette axonemaler Dyneine (UhImann et al., 2007) und ist auf dem gleichen Chromosom wie CD9 lokalisiert. Bei der Resequenzierung des DNAL4Gens wurden 23 Polymorphismen detektiert, davon waren zehn Polymorphismen bislang nicht beschrieben, 13 SNPs aus der dbSNP-Datenbank (NCBI) konnten bestätigt werden. Bei sechs SNPs konnte ein signifikanter Einfluss auf Spermienmotilität nachgewiesen werden. Diese wird definiert als der Anteil sich bewegender Zellen in einem Ejakulat und wird als ein wichtiger Indikator für die Befruchtungsfähigkeit angesehen (Broekhuijse et al., 2012). Der größte Effekt ging von SNP g.1007A>G im zweiten Intron des DNAL4-Gens aus. Dieser SNP ist aufgrund des Substitutionseffekts mit signifikant niedrigerer Motilität des nativen Ejakulats (MOTUD) als auch nach 24- bzw. 48stündiger Lagerung (MOT1 bzw. MOT2) assoziiert. Dabei zeigen sich für MOTUD signifikante Unterschiede zwischen allen Genotypen, bzw. zwischen den Genotypen AA und AG sowie AA und GG für MOT1 und MOT2.

Dass auch intronische Varianten nicht funktionslos sein müssen, wurde durch zahlreiche Studien belegt. Introns weisen eine wesentlich größere Mutationsrate auf, als lange angenommen wurde, da sie eine Vielzahl funktioneller Elemente enthalten (Cooper, 2010), wie cis-Elemente (Silencer, Enhancer), die alternatives Spleißen regulieren (Wang et al., 2009) oder trans-Elemente (Gingeras, 2009). Einige intronische Polymorphismen treten zwar nicht innerhalb der Spleißstellen auf, können aber dennoch beispielsweise zur Intron-Retention führen (Kwan et al., 2008). Weiterhin können stille Mutation einen Einfluss auf die RNA-Stabilität (Capon et al., 2004) bzw. die Proteinfaltung (Kimchi-Sarfaty et al., 2007) haben. Es ist außerdem möglich, dass es sich bei der Variante g.1007A>G um einen indirekten Marker handelt, der das kausale Gen beispielsweise durch Beeinflussung dessen Promotors, reguliert (Wiedemann et al., 2018a). Dies könnte zu einer Einschränkung der Flagellentätigkeit führen, die durch die Aktivität der Dyneine bedingt wird.

Weiterhin zeigen die Daten einen Einfluss von g.1007A>G auf Halsmittelstückdefekte. Da der Flagellenschlag vom Axonem abhängt, das in verschiedene regulatorische Systeme im Halsmittelstück und Spermienschwanz eingebunden ist (Harris et al., 2007), ist ein Einfluss sowohl auf die Spermienmotilität, als auch auf Halsmittelstückdefekte 
nachvollziehbar. Zwei strukturelle Veränderungen, die zu verdickten Halsmittelstücken führen können, sind die Schwellung oder unregelmäßige Anordnung von Mitochondrien. Die mitochondriale Schwellung betrifft zumeist die ersten Mitochondrien der Mitochondrienscheide, deren Durchmesser um das Fünffache vergrößert sein kann (Briz \& Fàbrega, 2013). Axonemale Dyneine haben einen hohen ATP-Bedarf, um die Bewegung des Flagellums zu gewährleisten (Turner, 2003). Dieser wird aus verschiedenen örtlich festgelegten Energiequellen gedeckt. Die oxidative Phosphorylierung ist auf das Halsmittelstück beschränkt, in dem das Axonem von einer dichten Faserschicht mit Mitochondrien umgeben ist (Miki et al., 2004). Scheinbar wird jedoch der größte Teil der Energie für die Spermienmotilität durch Glykolyse erzeugt. Glycerinaldehyd-3phosphat-Dehydrogenase (GAPDH) ist ein zentrales Enzym des GlykolyseStoffwechsels. Eine ausschließlich in den Spermien exprimierte Variante von GAPDH, GAPDS, scheint hauptverantwortlich für die Motilität der Spermien zu sein (Miki et al., 2004). Sollte nicht ausreichend Energie aus der Glykolyse bereit gestellt werden, wird die gesamte ATP-Versorgung des Spermiums aus den Mitochondrien bezogen (Cardullo \& Baltz, 1991). Unter der Annahme, dass durch das G-Allel von g.1007A>G die Funktion der Dyneine beeinträchtigt ist, könnte eine Einschränkung bei der Umsetzung von ATP vorliegen. Auf der einen Seite wäre dies durch eine verminderte Motilität der Spermien sichtbar. Auf der anderen Seite könnte eine vermehrte ATPProduktion aus den Mitochondrien zum Ausgleich des Energiedefizits dazu führen, dass das Halsmittelstück durch eine Vergrößerung der Mitochondrien (mitochondrial swelling) verdickt wird. Eine weitere mögliche Erklärung wäre, dass der Dominanzeffekt des A-Allels auf Motilitätsparameter darauf schließen lässt, dass dieses einen Einfluss bei der Bildung des Halsmittelstücks spielt und wichtig für die Funktion des Spermiums ist.

Die vorgestellte Assoziationsanalyse bestätigt die Wichtigkeit von DNAL4 als mögliches Kandidatengen oder indirekter Marker für Motilitätsparameter und Halsmittelstückdefekte von Spermien. Verbunden mit dem Einfluss von g.358A>T im CD9-Gen auf Spermienmotilität und das Vorhandensein von Plasmatropfen (Kaewmala et al., 2011) gibt es Hinweise, dass das porzine Chromosom 5 mit männlicher Fruchtbarkeit assoziiert ist (Wiedemann et al., 2018a). 


\section{Expressionsanalyse ausgewählter boviner PAG-Gene (boPAG)}

\subsection{Einleitung}

Die erfolgreiche Etablierung und Aufrechterhaltung einer Trächtigkeit ist der wichtigste Faktor einer wirtschaftlichen Milch- oder Fleischrinderhaltung. Die Plazentation ist in diesem Kontext ein kritischer Schritt. Sie setzt beim Rind ab dem 27. - 28. Trächtigkeitstag ein (King et al., 1979; Aires et al., 2014). Hierbei erfolgen die Adhäsion fetaler Kotyledonen mit maternalem Karunkelgewebe und infolgedessen die Bildung von Plazentomen (King et al., 1979).

Wiederkäuer besitzen im Gegensatz zu den meisten Paarhufern keine Placenta diffusa (epitheliochoriale Plazenta), sondern eine Placenta multiplex seu cotyledonaria (syndesmochoriale Planzenta), die einige Besonderheiten aufweist (King, 1993). Die syndesmochoriale Plazenta besitzt morphologisch unterschiedliche Zelltypen (Green et al., 2000). In der frühen Trächtigkeit kommen hier neben einkernigen Epithelzellen auch binukleäre Zellen (BNCs) vor. BNCs treten das erste Mal vor der Implantation im Gewebe des Trophoblasten auf (Koshi et al., 2012; Reese et al., 2016) und entstehen aus mononukleären Trophoblastzellen über mitotische Polyploidie (Wathes \& Wooding, 1980; Wooding, 1983, 1984). Um den 25. Tag der Gravidität machen sie bis zu $20 \%$ der Zellen des Trophektoderms aus und stellen den invasiven Teil der Trophoblasten dar, das heißt einige von ihnen können nach der Anheftung mit dem maternalen Uterusepithel verschmelzen (Green et al., 2000; Green et al., 2005). Daraus bilden sich mehrkernige fetal-maternale Syncytiumzellen (Wooding, 1992; Abbildung 3-1). BNCs sind in der Lage Stoffe durch Exozytose über die Basalmembran in den maternalen Blutkreislauf abzugeben (Green et al., 2000). Zu den sezernierten Stoffen zählen neben plazentarem Laktogen, Prolaktin, Wachstumshormonen und faktoren auch trächtigkeitsassoziierte Glykoproteine (pregnancy-associated glycoproteins, PAG) (Hashizume, 2007; Reese et al., 2016). 


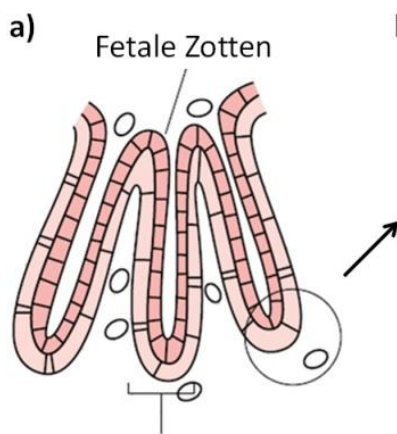

Maternale Krypten b)

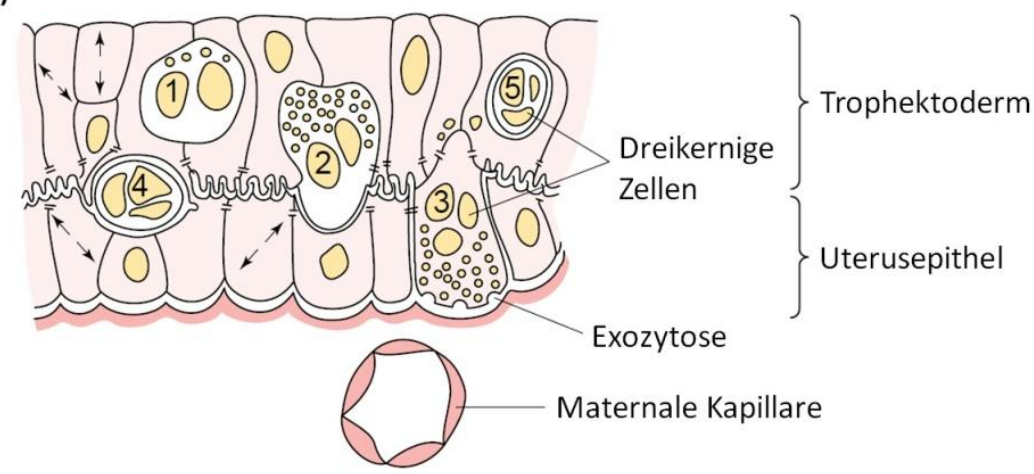

Abbildung 3-1: Migration und Fusion binukleärer Zellen in der Wiederkäuer-Plazenta (modifiziert nach Green et al., 1998b).

a) Ausschnitt eines vollentwickelten Plazentoms fetale Zotten der Kotyledone penetrieren die maternalen Krypten des Chorions. b) Fetomaternale Syncytiumzellen entstehen durch Migration und Fusion $(1,2)$ der BNCs. Aus ihnen entstehen kurzlebige dreikernige Zellen (3), die nach Exozytose vom Trophektoderm resorbiert werden $(4,5)$. Die Granula der BNCs können in maternale Kapillare gelangen.

\subsubsection{Struktur und Funktion boviner PAGs}

Trächtigkeitsassoziierte Glykoproteine wurden in den 1980'er Jahren entdeckt, als nach spezifischen Markern zur Erkennung einer Trächtigkeit geforscht wurde (Reese et al., 2016). Das "pregnancy-specific protein B" (PSPB) wurde erstmals von Butler et al. (1982) und Sasser et al. (1986) erwähnt. Beckers et al. (1988) identifizierten das "pregnancy-associated glycoprotein-2" (PAG-2). Zoli et al. (1991) isolierten aus bovinen Kotyledonen verschiedene Varianten eines Glykoproteins, die nahezu identisch zu dem von Sasser et al. (1986) beschriebenen PSPB waren und fasste sie als "pregnancyassociated glycoproteins" (PAG) zusammen. Diese Glykoproteine zählen zur Familie der Aspartat-Proteasen (u. a. Xie et al, 1991; Green et al., 2000; Szafranska et al., 2006; Chentouf et al., 2008). PSPB war das erste bekannte trächtigkeitsassoziierte Mitglied der Aspartat-Proteasen (Butler et al., 1982).

Aspartatproteasen sind proteolytisch aktive Enzyme, die der Pepsinfamilie angehören und in saurem Milieu agieren (Tang \& Wong, 1987). Ein Merkmal dieser Enzymfamilie ist unter anderem die hochkonservierte Sequenz Asp-Thr-Gly-Ser/Thr-Ser/Thr (DTGS/TS/T) (Green et al., 2000 nach Davies, 1990). So besitzen das bovine (boPAG) und ovine (ovPAG) PAG-1 eine über 70 prozentige Sequenzhomologie (Guruprasad et 
al., 1996): bei boPAG-1 wird das konservierte Glyzin in der DTG Sequenz zu Alanin (DTA) und bei ovPAG-1 wird Asparaginsäure zu Glyzin (GTG) substituiert (Xie et al., 1991). Des Weiteren zeigen die PAGs eine hohe Sequenzhomologie zu anderen Aspartatproteasen wie beispielsweise Pepsin und Cathepsin D und E und teilen etwa 50 \% der Aminosäure-Sequenz mit der Pepsinogen-Familie (de Sousa et al., 2006).

Bis heute wurden PAGs aus Plazentagewebe bzw. Kotyledonen verschiedener Säugetiere isoliert (Tabelle 3-1). Die einzelnen PAGs unterscheiden sich durch ihr Molekulargewicht (30 bis 90 kDa; Szafranska et al., 2006), welches im Mittel bei etwa 55 kDa bis 70 kDa liegt (de Sousa et al., 2006) und durch den Isoelektrischen Punkt, der zwischen 4,4 pl und 5,4 pl liegt (Zoli et al., 1991).

Phylogenetische Studien teilen PAGs, basierend auf dem Zeitraum ihrer Entstehung, in zwei Gruppen ein. "Anzestrale" PAGs haben ihren Ursprung vermutlich vor etwa 87 Millionen Jahren, "moderne" PAGs hingegen erst vor 52 Millionen Jahren (Hughes et al., 2000). Die Mehrzahl der PAGs gehört der modernen Gruppe an. Diese wurde nur bei Wiederkäuern, hauptsächlich Boviden, nachgewiesen (Wallace et al., 2015). Anzestrale PAGs weisen alle Charakteristika von Aspartatproteasen auf, weshalb sie proteolytisch aktiv sein könnten (Xie et al., 1991; Guruprasad et al., 1996; Telugu et al., 2010). Moderne PAGs können aufgrund eines Aminosäureaustausches in der Nähe ihres katalytischen Zentrums keine enzymatische Aktivität aufweisen (Guruprasad et al., 1996; Xie et al., 1997; Wooding et al., 2005; Szafranska et al., 2006). Diese PAGs binden vermutlich andere Proteine oder besitzen atypische Bindestellen, wie es auch bei verschiedenen Plasmepsinen beschrieben ist (Berry et al., 1999; Banerjee et al., 2002; Wooding et al., 2005). 
Tabelle 3-1: Überblick über das Vorkommen von PAG-Genen in verschiedenen Spezies

\begin{tabular}{ll}
\hline Spezies & Autor \\
\hline Affe (Papio hamadryas) & Zhou \& Hammarstrom, 2001 \\
Alpaka (Lama pacos) & Majewska et al., 2011 \\
Bison (Bison bison) & Kiewisz et al., 2008 \\
Damhirsch (Dama dama) & Beriot et al., 2014 \\
Dromedar (Camelus dromedarius) & Majewska et al., 2013 \\
Elch (Alces alces) & Huang et al., 1999 \\
Giraffe (Giraffa camelopardalis) & Wooding et al., 2015 \\
Jangtse-Delfin (Lipotes vexillifer) & NCBl, 2014 \\
Hirsch (Odocoileus virginianus) & Osborn et al., 1996 \\
Katze (Felis catus) & Gan et al., 1997 \\
Lama (Lama glama) & Drew et al., 1995 \\
Maus (Mus musculus) & Chen et al., 2001 \\
Okapi (Okapi johnstoni) & Wooding et al., 2015 \\
Pferd (Equus caballus) & Green et al., 1998a; Green et al., 1999 \\
Ratte (Rattus norvegicus) & Das et al., 1994 \\
Rentier (Rangifer tarandus) & Ropstad et al., 2005 \\
Rind (Bos taurus) & Zoli et al., 1991; Klisch et al., 2005 \\
Schaf (Ovis aries) & Zoli et al., 1990 \\
Schwein (Sus scrofa) & Szafranska et al., 1995 \\
Schwertwal (Orcinus orca) & NCBI, 2015 \\
Trampeltier (Camelus bactrianus) & Majewska et al., 2013 \\
Wapiti (Cervus elaphus nelsoni) & White et al., 1995 \\
Wasserbüffel (Bubalus bubalis) & Barbato et al., 2008; Barbato et al., 2013 \\
Wisent (Bison bonasus) & Kiewisz et al., 2009 \\
Zebu (Bos indicus) & de Sousa et al., 2002 \\
Ziege (Capra hircus) & Garbayo et al., 1998; de Sousa et al., 1999 \\
\hline
\end{tabular}

Zwar ist die genaue Funktion der PAGs noch ungeklärt, es wird aber vermutet, dass sie eine Rolle bei der biochemischen Umsetzung von Wachstumsfaktoren an der Schnittstelle zwischen Plazenta und Uterus spielen (Wooding et al., 2005). Einige PAG-Gene, die hauptsächlich an der feto-maternalen Schnittstelle exprimiert werden, könnten immunmodulatorische und luteotrophe Eigenschaften aufweisen und beispielsweise die Errichtung einer Immunbarriere zwischen beiden Oberflächen unterstützen (Wallace et al., 2015). Weems et al. (1999) schlossen aus ihren Untersuchungen, dass Östrogene die Sekretion von PSPB aus den Chorionzellen regulieren, welches die plazentare Sekretion von Prostaglandin $E_{2}\left(P E_{2}\right)$ beeinflussen kann. $P G E_{2}$ wiederum regt die Sekretion von Progesteron in der Trächtigkeitsmitte von Schafen an (Szafranska et al., 2006). 
Moderne PAGs werden in der frühen Phase der Trächtigkeit gebildet und scheinen daher eine Rolle bei der Implantation und Plazentation zu spielen (Ishiwata et al., 2003; de Sousa et al., 2006).

Der Nachweis von trächtigkeitsassoziierten Glykoproteinen im maternalen Kreislauf kann zur frühen Trächtigkeitsdiagnose, sowie zur Überwachung einer Trächtigkeit bei Kühen genutzt werden (Szafranska et al., 2006; Pohler et al., 2013; Wallace et al., 2015). Der Vorteil dieses Verfahrens liegt darin, dass es sich bei PAGs um ein fetales Produkt handelt, welches auf das maternale System übertritt (Szafranska et al., 2006).

\subsubsection{Expression boviner PAG-Transkripte}

Die mRNAs boviner PAG-Gene können, bei erfolgreicher Befruchtung, ab Tag 17 post coitum (p. c.) nachgewiesen werden (Szafranska et al., 2006). Sie unterliegen dabei unterschiedlichen räumlich-zeitlichen Expressionsmustern (Telugu et al., 2009; Wallace et al., 2015). Moderne PAGs werden ausschließlich in den invasiven binukleären Zellen synthetisiert (Green et al., 2000; Wooding et al., 2005), während anzestrale außerdem in den einkernigen Zellen des Trophoblasten exprimiert werden (Green et al., 2000; Hughes et al., 2003; Wooding et al., 2005). Bovine PAGs können aufgrund ihrer Expression in den Trophoblastenzellen in zwei Gruppen eingeteilt werden. Diese Einteilung scheint mit der phylogenetischen Gruppierung zu korrelieren. Die erste Expressionsstudie boviner PAG-Gene führten Green et al. (2000) durch. Sie zeigten, dass einige anzestrale PAG-Gene (boPAG-2, -8, -10 und -11) während der gesamten Trächtigkeit in der Plazenta nachweisbar sind. Andere (moderne) werden nur in bestimmten Trächtigkeitsabschnitten exprimiert (Abbildung 3-2). So wurden boPAG-1, -6 und -7 beispielweise nur in der Mitte der Trächtigkeit zwischen dem 45. und 250. Trächtigkeitstag nachgewiesen. BoPAG-4, -5 und -9 werden zwar ab der frühen Trächtigkeit exprimiert, konnten aber zum Zeitpunkt der Geburt nicht mehr nachgewiesen werden (Green et al., 2000). 


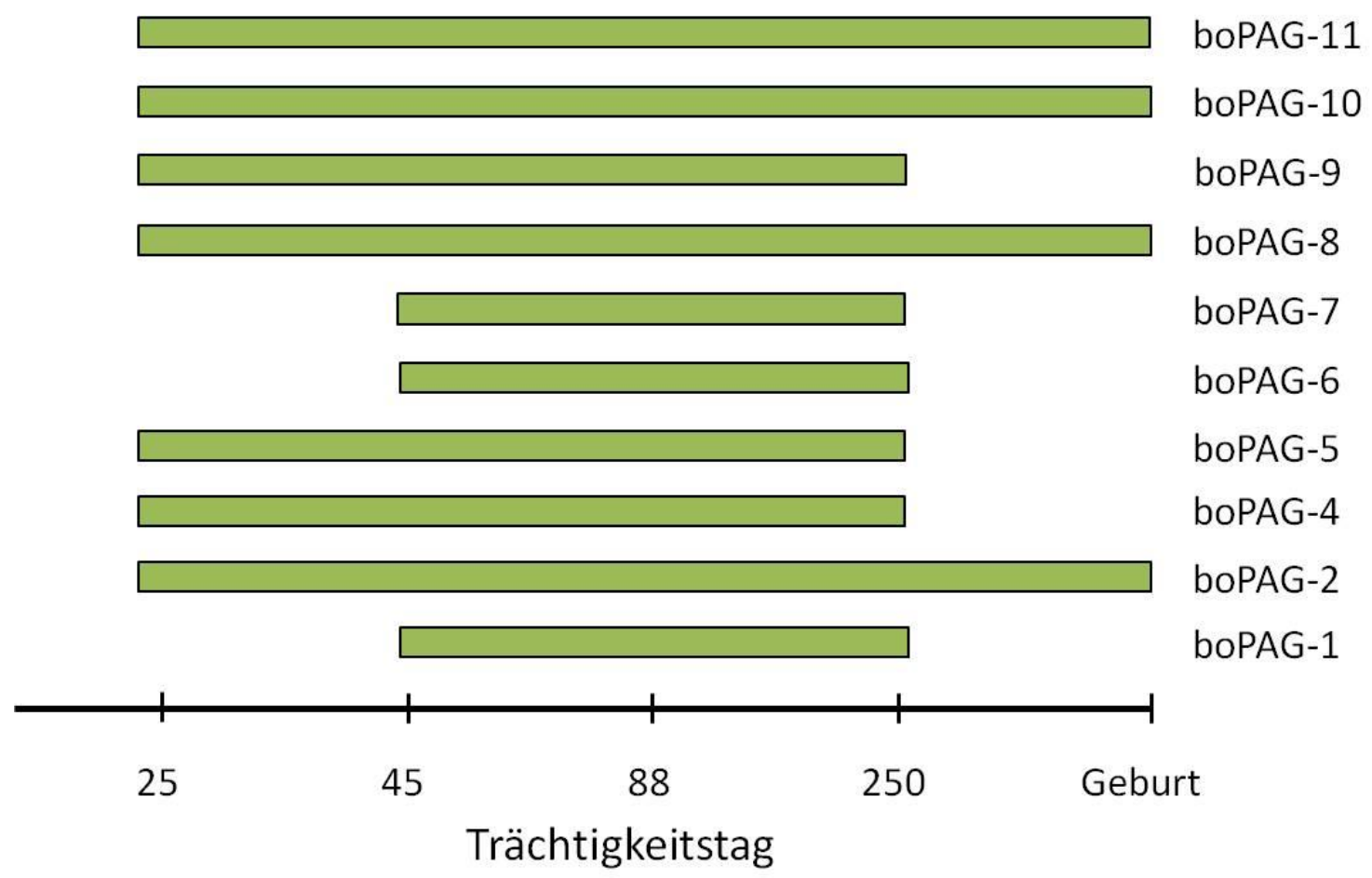

Abbildung 3-2: Expression boviner PAG-Gene im Verlauf der Trächtigkeit (modifiziert nach Green et al. (2000)).

Die ersten Studien zur relativen Quantifizierung von bovinen PAG-Transkripten in Plazentomgewebe wurden von Patel et al. (2004) und Telugu et al. (2009) durchgeführt (Wallace et al., 2015). Patel et al. (2004) zeigten, dass die Expression von boPAG-9 im Vergleich zu boPAG-1 im ersten Trimester zehnfach erhöht war. Die Expression von boPAG-8 und boPAG-11 ist ebenfalls in der frühen Trächtigkeit (Tag 45) am höchsten, während boPAG-10 kurz vor der Geburt am höchsten exprimiert wird (Telugu et al., 2009; Wallace et al., 2015).

Touzard et al. (2013) zeigten, dass die meisten (jedoch nicht alle) Transkripte moderner PAGs in Kotyledonen deutlich höher exprimiert werden, als in nachgelagertem Choriongewebe. BoPAG-1 und boPAG-2 sind sowohl in mono-, als auch in binukleären Zellen der Plazenta vorhanden (Touzard et al., 2013). Die Expression ihrer mRNA setzt mit Beginn der Implantation in der fetalen Plazenta ein (de Sousa et al., 2006). Das am häufigsten vorkommende PAG-Transkript ist boPAG-2. Sehr eng damit verwandt ist boPAG-12. Dieses kommt jedoch deutlich seltener vor (Telugu et al., 2009). 
Die Regulation der PAG-Transkription ist bislang noch nicht aufgeklärt (Wallace et al., 2015). Die regulatorischen Sequenzen vor dem Transkriptionsstart sind innerhalb der Genfamilie hoch konserviert und beinhalten mögliche Bindungsstellen für Transkriptionsfaktoren, die in die Transkriptionsregulation eingebunden sein könnten (Telugu et al., 2009).

Das Ziel dieser Studie war es detaillierte mRNA-Expressionsprofile für ausgewählte moderne (boPAG-1, -9, -21) und anzestrale (boPAG-2, -8, -10, -11, -12) bovine PAGGene mit einer hohen Messdichte, besonders in der frühen Trächtigkeit, darzustellen. Die Charakterisierung dieser Expressionslevel liefert wichtige Einblicke für spätere Proteinanlaysen, die für die Entwicklung neuer Trächtigkeitserkennungssysteme dienen können. 


\title{
3.2 mRNA expression profiling in cotyledons reveals significant up-regulation
} of the two pregnancy-associated glycoprotein genes boPAG-8 and boPAG-11 in early gestation

Wiedemann, I., Krebs, T., Momberg, N., Knorr, C., Tetens, J.

Department of Animal Sciences, University of Goettingen, Germany

\author{
veröffentlicht in \\ Veterinary Medicine and Science, 4(4): 441-450 \\ URL: https://onlinelibrary.wiley.com/doi/full/10.1002/vms3.123 \\ DOI: $10.1002 / v m s 3.123$
}




\section{Abstract}

Background: The multigene family of pregnancy-associated glycoproteins (PAGs) belongs to a group of aspartic proteases that are exclusively expressed by trophoblast cells in the placenta of even-toed ungulates. In Bovidae, 22 different PAG genes (boPAGs) with a wide range of temporal and spatial expression- and glycosylation patterns have been reported to date.

Objectives and Methods: In this study we describe the mRNA expression patterns using real-time quantitative PCR (qPCR) for selected modern (boPAG-1, -9, -21) and ancient bovine PAGs (boPAG-2, $-8,-10,-11,-12$ ) in cotyledonary tissue.

Results: The highest mean expression was detected in boPAG-8 and lowest in boPAG$10(p<0.05)$. Furthermore, boPAG-8 and -11 were significantly greater expressed in early gestation compared with later pregnancy stages.

Conclusion: The characterization of boPAG mRNA-expression levels gives important insights for further protein analyses which will be valuable information for the development of new pregnancy detection systems.

Keywords: bovine, pregnancy, pregnancy-associated glycoproteins, mRNA-expression, placenta 


\section{Introduction}

Changes in gene expression are associated with the development of the blastocyst from the morula to the embryo. Some genes that are transcribed only in the trophectoderm are activated during pregnancy for the first time (Green et al., 2000).

Subsequent research in this field has revealed that multigene families are expressed in the reproductive tract of mammalian species during this period of life (Green, 2004; Telugu, Walker, \& Green, 2009). Pregnancy associated glycoproteins (PAGs) are an example of this type of family. PAGs and PAG-like proteins can be found in numerous different species (e.g.de Sousa, Ayad, Beckers, \& Gajewski, 2006; Szafranska, Panasiewicz, \& Majewska, 2006), but they are mainly expressed by the trophoblast cells of members of the Cetartiodactyla order (Wallace, Pohler, Smith, \& Green, 2015) where they represent one of the major secretory products (Szafranska, Xie, Green, \& Roberts, 1995; Xie, Green, Bao et al., 1997; Xie, Green, Bixby et al., 1997; Garbayo et al., 1998; Green et al., 2000; Brandt, Parks, Killian, Ealy, \& Green, 2007).

PAGs belong to the vertebrate aspartic proteinase family. Therefore, they are directly related with a number of enzymes such as pepsin, chymosin, cathepsin $D$ or renin (Hughes, Green, Piontkivska, \& Roberts, 2003). Based on this relationship, a proteolytic activity in some PAGs has been discussed by different authors (Green, Xie, Gan, \& Roberts, 1998; Telugu et al., 2009; Telugu, Palmier, Van Doren, \& Green, 2010). They are suspected to play a role in the biochemical processing of latent growth factors at the placenta-uterine interface (Wooding, Roberts, \& Green, 2005). On the other hand there are a lot of bovine PAGs (boPAGs) incapable of being enzymatically active due to amino acid substitutions around the catalytic site (Guruprasad et al., 1996; Szafranska et al., 2006; Wooding et al., 2005; Xie, Green, Bixby et al., 1997). These PAGs are hypothesized to bind other proteins or consist of an atypical binding site as described in several plasmepsins (Banerjee et al., 2002; Berry et al., 1999; Wooding et al., 2005). Despite the above-mentioned functions, PAGs have been proposed to have immunomodulatory and luteotrophic actions (Wallace et al., 2015).

In the Bovidae 22 different PAG genes with a wide range of temporal and spatial expression- and glycosylation patterns have been identified (Telugu et al., 2009; Wallace 
et al., 2015). Bovine PAG are the subject of intense research but the exact number and function of boPAG and their closely related variants remain unclear (Telugu et al., 2009). There are different scientific perspectives on grouping the 22 boPAGs. Phylogenetic analyses have indicated that PAGs can be clustered into at least two groups that were termed 'ancient' and 'modern' based on the time when each group arose (Hughes, Green, Garbayo, \& Roberts, 2000). The ancient group is thought to have arisen around 87 million years ago, whereas the modern one has arisen around 52 million years ago. Beside the difference in the date of origin both groups are transcribed in different cell types. The modern group (e.g. boPAG-1, $-9,-21$ ) is expressed only in a subset of trophoblast cells, so called binucleated cells (BNC). They are formed in the early stages of pregnancy and have been suspected to play an important role in implantation and placentation (de Sousa et al., 2006; Ishiwata et al., 2003). In addition, they are ideally positioned to adapt or regulate the maternal immune system to pregnancy (Szafranska et al., 2006; Wooding et al., 2005). Furthermore, boPAG-1 is the most commonly used PAG for pregnancy diagnosis in cattle (Wallace et al., 2015). The ancient group (e.g. boPAG-2, $-8,-10,-11,-12$ ) can be found in all trophoblast cells (Green et al., 2000; Hughes et al., 2000; Telugu et al., 2009; Wallace et al., 2015; Wooding et al., 2005). A group of PAG genes (e.g. boPAG-2) that are expressed mainly at the fetal maternal interface may have an impact on the fetal-to-maternal surface attachment or the establishment of an immune barrier between both surfaces (Wallace et al., 2015).

To date there are only a few studies about detailed boPAG expression patterns throughout pregnancy. Comparison between these studies is difficult as the results are either inconsistent or show a low coverage of pregnancy days (e.g. only specific test days but no expression profiles). Although modern PAGs are well characterized in the maternal circulation (Sasser, Ruder, Ivani, Butler, \& Hamilton, 1986; Friedrich \& Holtz, 2010) detailed information about their mRNA expression up to day 60 post conceptionem (p. c.) are missing. The aim of this study was to illustrate detailed mRNA expression profiles for selected modern (boPAG-1, -9, -21) and ancient (boPAG-2, -8, -10, -11, -12) bovine PAGs with a high density of measurements, especially in early gestation and throughout pregnancy using real-time quantitative PCR 
(qPCR). The characterization of boPAG mRNA-expression levels provides important insights for further protein analyses which are valuable information for developing new pregnancy detection systems.

\section{Materials and Methods}

\section{Sample Collection}

Bovine cotyledonary tissue was collected at a local abattoir. Two samples from three different cotyledons per animal were taken as biological replicates. Cotyledons of similar size and location were collected by manual separation of placentomes within 30 min of slaughter. The pregnancy stage was estimated via fetal crown-rump-length (Rexroad, Casida, \& Tyler, 1974) and divided into three groups: early pregnancy (day $20-90, \mathrm{~N}=12$ ), mid pregnancy (day $91-180, \mathrm{~N}=11$ ) and late pregnancy (day 181 - parturition, $\mathrm{N}=1$ ). Fifty $\mathrm{mg}$ of tissue per cotyledon were washed with 1xPBS $\left(137 \mathrm{mM} \mathrm{NaCl}, 2.7 \mathrm{mM} \mathrm{KCl}, 4.3 \mathrm{mM} \mathrm{Na}_{2} \mathrm{HPO}_{4} \cdot 2 \mathrm{H}_{2} \mathrm{O}, 1.4 \mathrm{mM} \mathrm{KH}_{2} \mathrm{PO}_{4}\right)$ and transferred in $1.5 \mathrm{ml}$ RNAlater (Sigma Aldrich, Germany), stored at $4^{\circ} \mathrm{C}$ overnight and at $-20^{\circ} \mathrm{C}$ until RNA extraction.

\section{RNA extraction}

Total RNA was extracted using TriZol Reagent (Life Technologies, USA). The protocol was followed according to the manufacturer's recommendation with minor modifications: Samples were removed from RNAlater and briefly washed with 1x PBS, made free from fetal and maternal membranes, dissected in Petri dishes and subsequently homogenized in $1 \mathrm{ml}$ TriZol Reagent using a FastPrep ${ }^{\circledR}$ FP120 Cell Disrupter (Qbiogene, USA) two times for $15 \mathrm{sec}$ at $4 \mathrm{~m} / \mathrm{s}$. RNA was precipitated in ice-cold isopropyl alcohol and then washed in $1 \mathrm{ml}$ of $80 \%$ ethanol. RNA pellets were eluted in 50-150 $\mu$ l RNasefree water (Ambion, USA) depending on the pellet size. The RNA quantity and quality 
was checked immediately after RNA extraction, samples were then reverse transcribed and stored at $-80^{\circ} \mathrm{C}$ afterwards.

\section{Assessment of RNA quantity and quality}

The RNA concentration was measured at a wavelength of $260 \mathrm{~nm}$, and the purity of RNA was assessed by the absorbance at $230 \mathrm{~nm}$ and $280 \mathrm{~nm}$ with a NanoPhotometer ${ }^{\circledR}$ P-360 spectrophotometer (Implen, Germany). The RNA quality number (RQN) was evaluated using a microchip electrophoresis on a Fragment Analyzer (Advanced Analytical Technologies Inc., USA) in a core laboratory (Transcriptome and Genome Analysis Laboratory Goettingen, Germany).

Genomic DNA contamination was tested by endpoint PCR using intron spanning primers specific to bovine $C D H 1$ and PAG-genes (Table 1).

\section{cDNA synthesis}

Reverse transcription was performed using the High Capacity cDNA Reverse Transcription Kit (Applied Biosystems, USA). A fixed amount of 500 ng total RNA was reverse transcribed at $37{ }^{\circ} \mathrm{C}$ in a final volume of $20 \mu$ l containing $2 x$ RT-Buffer, $2 x$ RT Random Primers, $50 \mathrm{U}$ MultiScribe ${ }^{\mathrm{TM}}$ Reverse Transcriptase, $4 \mathrm{mM}$ dNTPs and $20 \mathrm{U}$ RNase Inhibitor. CDNA samples were stored at $-20^{\circ} \mathrm{C}$. 
Table 1: Oligonucleotides used for qPCR to measure relative expression levels of bovine PAG-genes during pregnancy

\begin{tabular}{|c|c|c|c|c|c|}
\hline \multirow{2}{*}{ Gene } & \multirow{2}{*}{ Accession Number } & \multirow{2}{*}{ Primer } & \multirow{2}{*}{ Sequence (5'-3') } & \multicolumn{2}{|c|}{ Product size (bp) } \\
\hline & & & & CDNA & gDNA \\
\hline \multirow{2}{*}{ boPAG-1 } & \multirow{2}{*}{ NM_174411.2 } & for & TAGGCTCATCGGTGCCATAC & \multirow{2}{*}{116} & \multirow{2}{*}{203} \\
\hline & & rev & GACCTGGCACTGGGTAGTTG & & \\
\hline \multirow{2}{*}{ boPAG-2 } & \multirow{2}{*}{ NM_176614.1 } & for & TCCTGGAGGAACAAGCTTACA & \multirow{2}{*}{149} & \multirow{2}{*}{1111} \\
\hline & & rev & TGAGCCTGTGTCAAAGACGA & & \\
\hline \multirow{2}{*}{ boPAG-8 } & \multirow{2}{*}{ NM_176619.3 } & for & GACACCGGCTCATCTGACTT & \multirow{2}{*}{139} & \multirow{2}{*}{229} \\
\hline & & rev & CAGAGCCGTAGACGAGTTCA & & \\
\hline \multirow{2}{*}{ boPAG-9 } & \multirow{2}{*}{ NM_176620.2 } & for & TGAAGTGGATTGTGCTCCTC & \multirow{2}{*}{149} & \multirow{2}{*}{1228} \\
\hline & & rev & CTGGGACAGTCTGTAAGGATGC & & \\
\hline \multirow{2}{*}{ boPAG-10 } & \multirow{2}{*}{ NM_176621.3 } & for & TTGAGCAGTCAGAAAGAGAACG & \multirow{2}{*}{137} & \\
\hline & & rev & TTCATGGAGATGCTGTCTATGTTT & & \\
\hline \multirow{2}{*}{ boPAG-11 } & \multirow{2}{*}{ NM_176623.2 } & for & GAAGATGACAGGAGGCAGGATAC & \multirow{2}{*}{138} & \multirow{2}{*}{221} \\
\hline & & rev & GTGGATACCGGGACATCACT & & \\
\hline \multirow{2}{*}{ boPAG-12 } & \multirow{2}{*}{ NM_176622.1 } & for & TCCTGGAAGAACGAGCTTACA & \multirow{2}{*}{149} & \multirow{2}{*}{1113} \\
\hline & & rev & TGAGCCTGTGTCAAAGACGA & & \\
\hline \multirow{2}{*}{ boPAG-21 } & \multirow{2}{*}{ NM_176630.2 } & for & TACAGGCTCATCTGACTTTTGG & 101 & 210 \\
\hline & & rev & CTCCCAGATCCATAGGTGATGC & 141 & 240 \\
\hline $\mathrm{CDH} 1$ & NM 001002763.1 & for & TGCCCAGAAAATGAGAAAGG & 99 & 225 \\
\hline CDHI & INIVI_UOIUOZ/OS.1 & rev & TTGGCCAGTGATGCTGTAGA & 99 & $\angle \angle 5$ \\
\hline YHWAG & NM 174793 & for & AGCACATGCAGCCCACTC & 121 & - \\
\hline 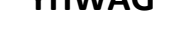 & 20.2 & rev & TCGTCGAAGGCGGTCTTG & 124 & 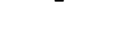 \\
\hline
\end{tabular}

qPCR analysis

Relative expression levels of selected PAG-genes in cotyledons were determined using real-time quantitative PCR (qPCR) with EvaGreen detection. Cadherin-1 (CDH1) and Tyrosine 3-Monooxygenase/Tryptophan 5-Monooxygenase Activation Protein Gamma (YWHAG) were selected as reference genes for normalization. Primer pairs for $\mathrm{CDH} 1$, boPAG-1, $-2,-8,-9,-11,-12$ and -21 were designed using primer3 software (http://bioinfo.ut.ee/primer3-0.4.0/) and their specificity checked with NCBI PrimerBLAST (https://www.ncbi.nlm.nih.gov/tools/primer-blast/). Primers for $Y W H A G$ and boPAG-10 were obtained from Telugu et al. (2009). Each PCR-fragment was sequenced and aligned to the corresponding reference sequence. The specificity was evaluated by Nucleotide-BLAST (https://blast.ncbi.nlm.nih.gov/Blast.cgi?PROGRAM=blastn\&PAGE_ TYPE=BlastSearch\&LINK_LOC=blasthome) prior to qPCR-analyses to assess the amplification of the correct gene. All primers used in this study including their applications are given in Table 1. 
PCR-products were amplified using $2 \mu \mathrm{l}$ of cDNA, $5 \mathrm{mM}$ dNTPs (Roche, Switzerland), $10 \mu \mathrm{M}$ of each primer (Sigma Aldrich, Germany), $0.5 \mu \mathrm{l}$ EvaGreen (JenaBioscience, Germany) and $1.5 \cup$ FastStart Taq-Polymerase in 1x PCR buffer containing $\mathrm{MgCl}_{2}$ and 1x GC-Solution (Roche, Switzerland) in a final volume of $25 \mu \mathrm{l}$. For amplification of boPAG-11 1x Sulfolane (Sigma Aldrich, Germany) was added to the reaction mix.

PCRs were performed in a Stratagene Mx3005P real-time cycler (Agilent, USA) with the following thermal profile: 38 cycles of $30 \mathrm{~s}$ at $95^{\circ} \mathrm{C}, 30 \mathrm{~s}$ at $56^{\circ} \mathrm{C}$ and $30 \mathrm{~s}$ at $72{ }^{\circ} \mathrm{C}$ with an additional 10-min denaturation in the first cycle. The amplification was followed by a melting curve measurement with $1 \mathrm{~min}$ at $95^{\circ} \mathrm{C}, 30 \mathrm{~s}$ at $70^{\circ} \mathrm{C}$ then heating the samples to $95^{\circ} \mathrm{C}$, where the change in fluorescence was measured at each $0.5^{\circ} \mathrm{C}$ rise.

Amplification efficiencies were calculated using standard curves generated by serial dilutions of known concentrations of the target amplicons with six orders of magnitude. Samples were quantified by the $2^{-\Delta \Delta C T}$ method (Livak \& Schmittgen, 2001) or Pfaffl method (Pfaffl, 2001) respectively. For each transcript, PCR was performed in triplicate as technical replicates.

\section{Statistical analysis}

The experimental results were analyzed with R 3.2.2 (R Development Core Team, Austria). Expression levels were compared within different PAG-genes (boPAG-1, boPAG-2, boPAG-8, boPAG-10, bo-PAG-11, boPAG-12, boPAG-21) and different pregnancy stages (early, middle and late) with PAG-gene-pregnancy stage interactions using a two-way ANOVA. Post hoc evaluation was performed with Tukey's Honest Significant Difference (HSD) Test. 


\section{Results}

\section{Sample collection and RNA-extraction}

Cotyledonary tissue from 24 animals was collected and used for RNA extraction. RNAsamples were observed to have mean spectrometry values of $1.99 \pm 0.09$ for absorbance ratios A260/A280, on the other hand mean OD A260/A230 ratios were $1.4 \pm 0.4$. RQN values derived from a Fragment Analyzer (Advanced Analytical Technologies Inc., USA) were between 5.8 and 9.9. After quality assessment a total of 21 samples with two or three biological replicates remained in the study (early pregnancy: $N=11$; mid pregnancy: $\mathrm{N}=9$; late pregnancy: $\mathrm{N}=1$ ).

\section{qPCR}

Standard curves of all genes had efficiencies in the range of $95.1 \%$ to $103 \%$ and slopes in the range of -3.24 to -3.45 . Gene expression ratios for boPAG-8, $-9,-11,-12$ and -21 were determined by the $2^{-\Delta \Delta C T}$ method (Livak \& Schmittgen, 2001) and according to Pfaffl (2001) for boPAG-1, -2 and -10 due to higher differences in primer efficiencies between reference genes and boPAG-genes of interest (Figure 1).

All boPAG-genes of interest were detectable and could be quantified throughout the available pregnancy stages. A 2-way ANOVA indicated significant differences in the expression levels between PAGs $(p<0.001)$ and an interaction between boPAG-gene and pregnancy stage $(p<0.001)$ on the relative expression level. A significant overall pregnancy stage effect was not detected. In the next step a pairwise comparison using Tukey's HSD test was performed.

BoPAG-1 shows highest expression levels around the end of the first and second trimester. A similar pattern is given in boPAG-9 and, for the early pregnancy, in boPAG21 , which are members of the modern boPAG-group.

BoPAG-2 and -12 are the most closely related PAG-members in this investigation. Nevertheless, the expression patterns are only slightly similar with an increase towards the end of the early pregnancy and a decline between day 110 and 120 . 
BoPAG-8 has the highest mean expression level and boPAG-10 the lowest mean expression level, a significant difference in the mean expression level was observed in comparison with the other investigated PAGs $(p<0.05)$.

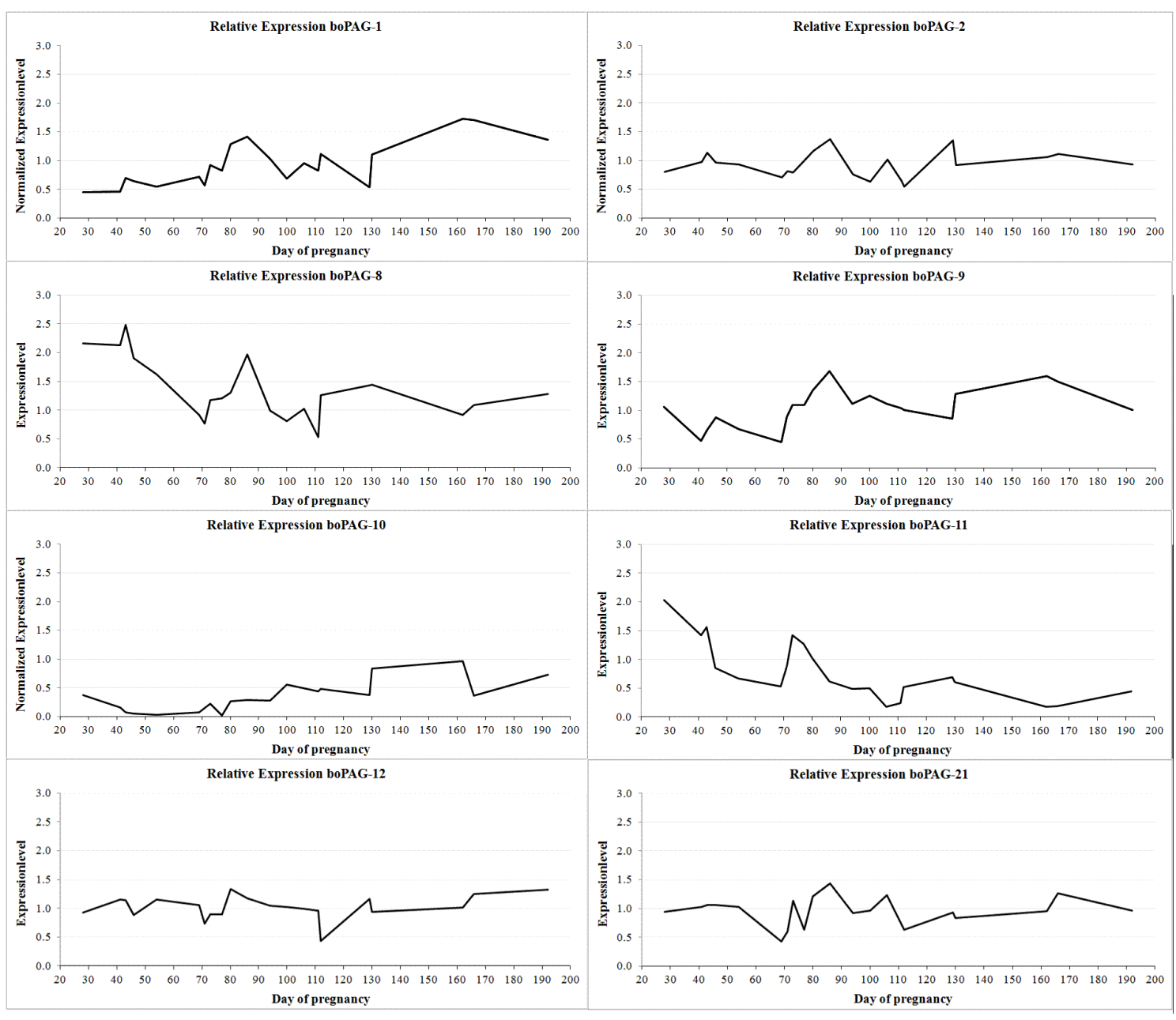

Figure 1: relative expression patterns of boPAG-1, -2, -8, -9, -10, -11, -12, -21. Expression levels for boPAG-1, -2 and -10 derived from efficiency-normalization by Pfaffl-method. Expression levels for boPAG-8, -9, -11, -12 and -21 were determined by $2^{-\Delta \Delta C T}$ method.

Besides that, boPAG-8, -10 and -11 transcripts show a mirror-inverted expression in cotyledonary tissue where boPAG-8 and -11 expressions are higher in the early gestation while boPAG-10 expression increases throughout pregnancy. BoPAG-1, $-2,-9,-11$, -12 and -21 are expressed on similar level throughout the different pregnancy stages (Figure 2). 


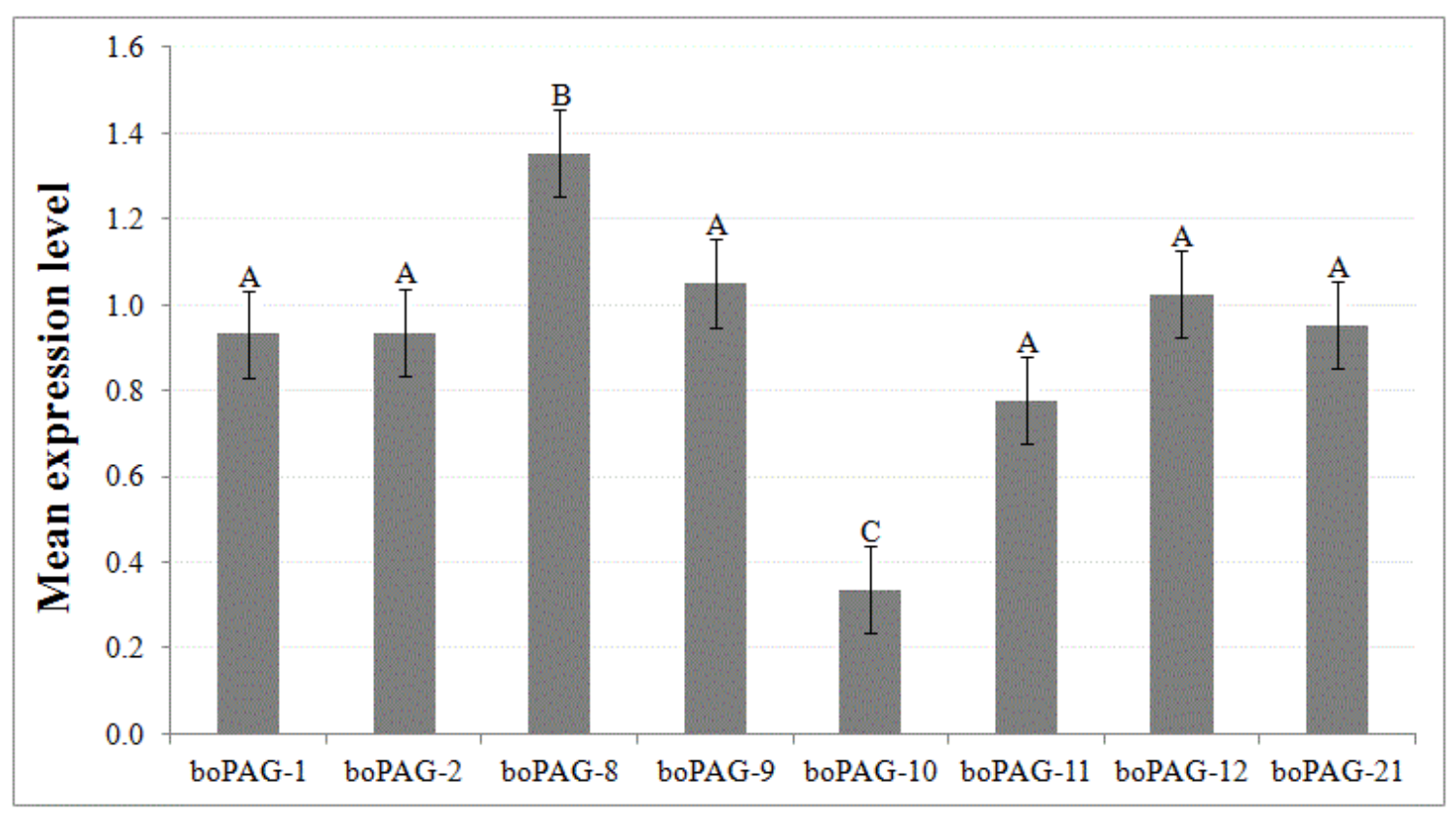

Figure 2: Differences in gene expression levels between observed boPAG-genes. Letters indicate significant differences $(p<0.05)$.

Pairwise comparison revealed that boPAG-8, which had the highest mean expression level in early pregnancy stage, decreases significantly from early pregnancy to mid pregnancy $(p<0.05)$ and remained at steady-state levels between mid pregnancy and late pregnancy. A similar effect to boPAG-8 was observed in boPAG-11 with a significant decrease in mean expression between early pregnancy and mid pregnancy $(p<0.001$ ) (Figure 3). In all other examined boPAGs no significant differences between the relative expression levels within the pregnancy stages were observed. 


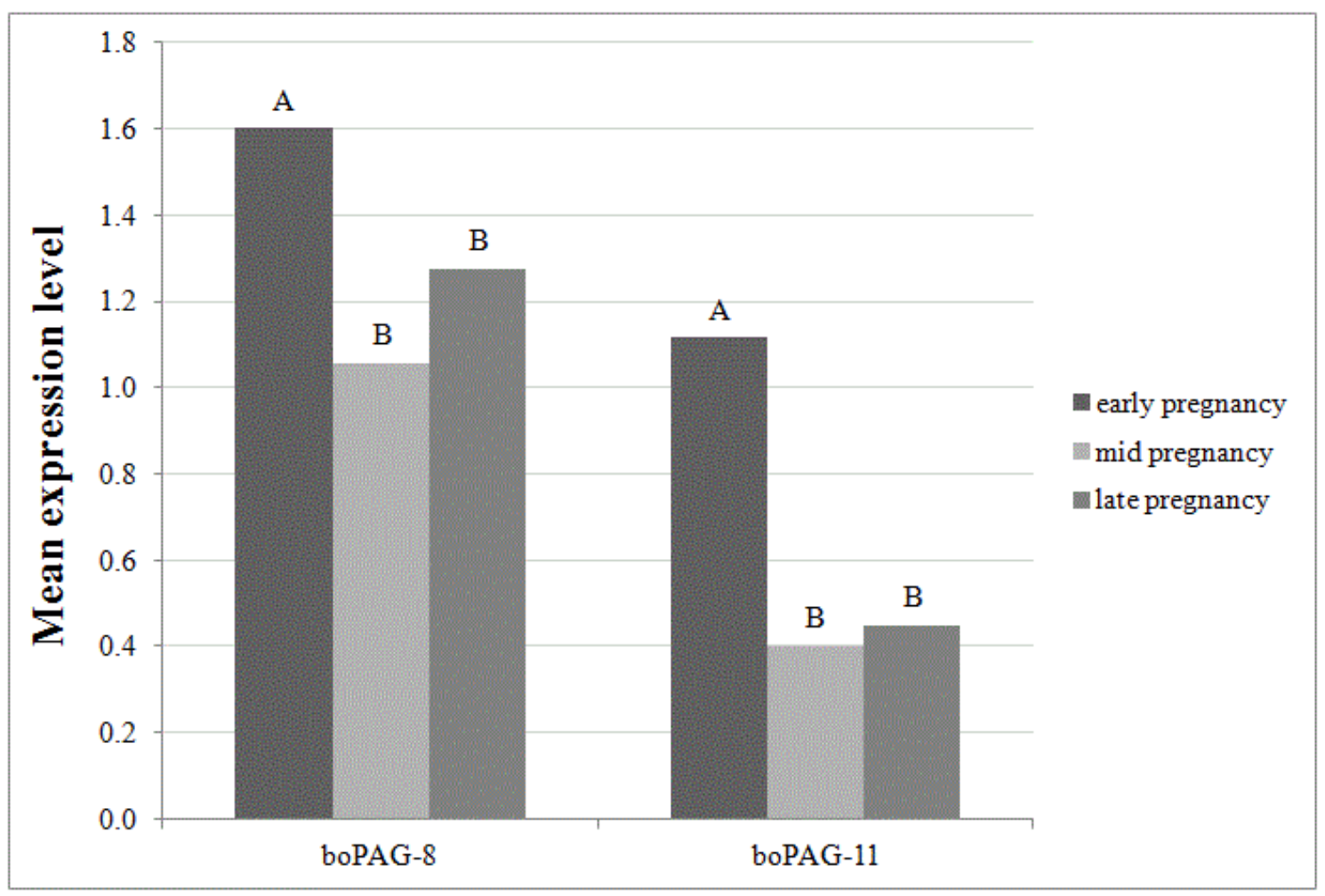

Figure 3: Differences in gene expression levels between different pregnancy stages. Letters indicate significant differences between pregnancy stages within boPAG- $8(p<0.05)$ and boPAG-11 $(p<0.001)$.

\section{Discussion}

To our knowledge, this is the first study describing mRNA expression profiles of both ancient and modern boPAG genes in cotyledons before day 60 p. c.. In contrast to other studies that examined expression levels from different boPAGs, we did not examine specific pregnancy days but collected samples continuously. Therefore we have been able to illustrate detailed patterns of boPAG expression, especially in early gestation from day 28 p. c. onwards.

Some of the first studies on the relative quantification of bovine PAG transcripts in placental tissue were reported by Patel et al. (2004) and Telugu et al. (2009). Patel et al. (2004) observed a significantly higher expression of boPAG-9 on day 30 of gestation compared to boPAG-1. Our results correspond to these findings, regarding a generally higher relative expression of boPAG-9 in cotyledonary tissue although we could not 
determine any significant differences. Furthermore, our results do not indicate a continuous increase of boPAG-9 expression from day 30 to day 60 as reported by Patel et al. (2004). Instead there is a decrease in-between.

Touzard et al. (2013) described lowest boPAG-1 levels at day 60 of gestation and a significant increase until day 80 . This expression pattern is in line with the present data, but boPAG-1 abundance increases from the beginning of gestation until day 60 .

In former studies performed by Telugu et al. (2009) boPAG-2 was found as the most abundant transcript. Although this cannot be confirmed by our results regarding relative expression levels, the absolute expression of boPAG-2 is higher than of other transcripts. Its most closely related transcript - boPAG-12 - did not show significant differences in relative expression patterns but it's absolute abundance is lower (results not shown). So far, boPAG-21 expression was analyzed in only one study with alternating up- and down-regulation (Touzard et al., 2013). Our results verify previous findings and additionally show that boPAG-21 is more highly expressed in the very early pregnancy and down-regulated until day 60 p.c.

The regulation of PAG transcription has not yet been elucidated (Wallace et al., 2015). The pre-transcriptional regulatory sequences are highly conserved within the gene family and include potential binding sites for transcription factors that might be involved in transcriptional regulation (Telugu et al., 2009).

Our results show that the relative expression of boPAG-8 is significantly higher throughout the whole pregnancy compared to the other PAG-genes. This confirms the study of Touzard et al. (2013) who also described the highest expression in boPAG-8. Furthermore, we confirm earlier studies on expression patterns of ancient boPAGgenes (Telugu et al. 2009): the expression of boPAG-8 and boPAG-11 is significantly higher in the early gestation and declines with progression of pregnancy with a short increase around day 80. In contrast to that boPAG-10 expression peaks in the end of second trimester, beginning of the last trimester respectively. Nevertheless, it is the least expressed transcript in our study. In general, the present study confirms further findings e.g. by Patel et al. (2004), Telugu et al. (2009) and Touzard et al. (2013) and expands the knowledge by more detailed information about boPAG-expression in early 
gestation. We collected samples from an abattoir and did not slaughter animals at fixed timepoints but determined the age of the fetuses by measuring the crown-rumplength which is an approximate standard for the normality of Holstein-Friesian fetal growth (Rexroad et al., 1974). Nevertheless, we obtained similar expression patterns as previously described. This shows that the method by Rexroad et al. (1974) is still a reliable tool for estimating the age of bovine fetuses, although breeding progress took place in the Holstein-Friesian cattle bread e.g. increased body size (Schönmuth \& Löber, 2006).

The low amount of samples for late pregnancies in this study is due to several reasons: on the one hand we generally observed better RNA-quality in samples from early gravidities compared to samples from mid or late pregnancies. This might be a result of higher time exposure during sample collection as the conjunction of placentomes is stronger and the detachment of cotyledonary tissue is more complicated. Previous studies already described that there is an effect of time exposure during tissue handling and RNA-integrity (Copois et al., 2007; Fajardy et al., 2009). The variability of gene expression profiles is dependent on the homogeneity of the starting material. The placenta consists of a large pattern of different cell types, fetal and maternal areas including blood of both individuals (Fajardy et al., 2009; Mondon et al., 2005). This leads to different expression patterns even in samples from one organism according to the (cell) composition of each sample. As a consequence samples or biological replicates, especially from pregnancies $>100$ days, were excluded from the analyses to ensure reliable results. Nevertheless, a minimum of two biological replicates per sample remained in the study. Another reason is a law that prohibits slaughtering healthy mammals (except goats and sheep) in the last third of gestation for commercial reasons, which came into force in September 2017 (TierErzHaVerbG, § 4). On the other hand we had a high coverage of measurement points especially for $<100$ days of pregnancy.

According to the different expression patterns of the analyzed boPAG genes, we suppose that boPAGs with a higher expression in early pregnancy (boPAG-8 and boPAG-11) seem to be important factors during placentation. Touzard et al. (2013) pointed out the restriction of boPAG-11 to binucleate cells located in the chorionic 
plate of the cotyledon. Therefore, they are ideally situated to accumulate at the placenta-uterine interface by acting as bridging molecules during cell-cell adhesion (Wallace et al., 2015).

The expression levels of boPAG-1, boPAG-9 and boPAG-10 are higher in the mid/late gravidity, which leads us to the suggestion that these PAGs might play a crucial role in maintenance of pregnancy. For boPAG-1, luteotrophic capabilities have already been described (Weems et al., 1998). Similar functions can be assumed for boPAG-2, boPAG-12 and boPAG-21.

\section{Conclusion}

In summary, it was possible to derive distinct longitudinal mRNA expression patterns and varying overall expression levels of eight different bovine PAGs in cotyledonary tissue across subsequent pregnancy stages. Although late pregnancy stages were underrepresented in our data, clear differences between early (pregnancy days 20-90) and later stages were found, especially for boPAG-8 and -11 indicating a possible role of these PAGs in placentation and the maintenance of early pregnancy.

\section{Acknowledgement}

The authors are deeply indebted to Julia Sondermann for the excellent technical assistance with the sample collection. 


\section{Source of Funding}

The study was financially supported by initial fundings provided by the University of Goettingen to CK.

\section{Contributions}

CK, IW and JT designed the study, TK collected samples, IW an NM performed molecular genetic analyses, TK analyzed the data, IW, TK and JT drafted the paper

\section{Conflict of interest}

The authors declare that they do not have any financial and personal relationships with other people or organizations that could inappropriately bias or influence their work.

\section{Ethical Statement}

The study is in accordance with the German legal and ethical requirements of appropriate animal procedures. Animals were not purposely euthanized for this study. Samples were taken during the conventional slaughter process. 


\section{References}

Banerjee, R., Liu, J., Beatty, W., Pelosof, L., Klemba, M., \& Goldberg, D. E. (2002). Four plasmepsins are active in the Plasmodium falciparum food vacuole, including a protease with an active-site histidine. Proc Natl Acad Sci U S A, 99(2), 990-995. doi:10.1073/pnas.022630099 022630099 [pii]

Berry, C., Humphreys, M. J., Matharu, P., Granger, R., Horrocks, P., Moon, R. P. (1999). A distinct member of the aspartic proteinase gene family from the human malaria parasite Plasmodium falciparum. FEBS Lett, 447(2-3), 149-154. doi:S0014-5793(99)00276-8 [pii]

Brandt, G. A., Parks, T. E., Killian, G., Ealy, A. D., \& Green, J. A. (2007). A cloning and expression analysis of pregnancy-associated glycoproteins expressed in trophoblasts of the white-tail deer placenta. Mol Reprod Dev, 74(11), 13551362. doi:10.1002/mrd.20669

Copois, V., Bibeau, F., Bascoul-Mollevi, C., Salvetat, N., Chalbos, P., Bareil, C. (2007). Impact of RNA degradation on gene expression profiles: assessment of different methods to reliably determine RNA quality. J Biotechnol, 127(4), 549559. doi:S0168-1656(06)00644-4 [pii] 10.1016/j.jbiotec.2006.07.032

de Sousa, N. M., Ayad, A., Beckers, J. F., \& Gajewski, Z. (2006). Pregnancy-associated glycoproteins (PAG) as pregnancy markers in the ruminants. I Physiol Pharmacol, 57 Suppl 8, 153-171.

Fajardy, I., Moitrot, E., Vambergue, A., Vandersippe-Millot, M., Deruelle, P., \& Rousseaux, J. (2009). Time course analysis of RNA stability in human placenta. BMC Mol Biol, 10, 21. doi:1471-2199-10-21 [pii] 10.1186/1471-2199-10-21

Friedrich, M. \& Holtz, W. (2010). Establishment of an ELISA for measuring bovine pregnancy-associated glycoprotein in serum or milk and its application for early pregnancy detection. Reprod Domest Anim, 45(1), 142-146. doi: RDA1287 [pii] 10.1111/j.1439-0531.2008.01287.x

Garbayo, J. M., Remy, B., Alabart, J. L., Folch, J., Wattiez, R., Falmagne, P. (1998). Isolation and partial characterization of a pregnancy-associated glycoprotein family from the goat placenta. Biol Reprod, 58(1), 109-115.

Green, J. A. (2004). Defining the function of a prolactin gene family member. Proc Natl Acad Sci U S A, 101(47), 16397-16398. doi:0406934101 [pii] 10.1073/pnas.0406934101

Green, J. A., Xie, S., Gan, X., \& Roberts, R. M. (1998). An aspartic proteinase expressed in the equine placenta. Adv Exp Med Biol, 436, 163-167.

Green, J. A., Xie, S., Quan, X., Bao, B., Gan, X., Mathialagan, N. (2000). Pregnancyassociated bovine and ovine glycoproteins exhibit spatially and temporally distinct expression patterns during pregnancy. Biol Reprod, 62(6), 1624-1631.

Guruprasad, K., Blundell, T. L., Xie, S., Green, J., Szafranska, B., Nagel, R. J. (1996). Comparative modelling and analysis of amino acid substitutions suggests that the family of pregnancy-associated glycoproteins includes both active and inactive aspartic proteinases. Protein Eng, 9(10), 849-856.

Hughes, A. L., Green, J. A., Garbayo, J. M., \& Roberts, R. M. (2000). Adaptive diversification within a large family of recently duplicated, placentally expressed genes. Proc Natl Acad Sci U S A, 97(7), 3319-3323. doi:10.1073/pnas.050002797 050002797 [pii] 
Hughes, A. L., Green, J. A., Piontkivska, H., \& Roberts, R. M. (2003). Aspartic proteinase phylogeny and the origin of pregnancy-associated glycoproteins. Mol Biol Evol, 20(11), 1940-1945. doi:10.1093/molbev/msg217 msg217 [pii]

Ishiwata, H., Katsuma, S., Kizaki, K., Patel, O. V., Nakano, H., Takahashi, T. (2003). Characterization of gene expression profiles in early bovine pregnancy using a custom cDNA microarray. Mol Reprod Dev, 65(1), 9-18. doi:10.1002/mrd.10292

Livak, K. J., \& Schmittgen, T. D. (2001). Analysis of relative gene expression data using real-time quantitative PCR and the 2(-Delta Delta C(T)) Method. Methods, 25(4), 402-408. doi:10.1006/meth.2001.1262 S1046-2023(01)91262-9 [pii]

Mondon, F., Mignot, T. M., Rebourcet, R., Jammes, H., Danan, J. L., Ferre, F. (2005). Profiling of oxygen-modulated gene expression in early human placenta by systematic sequencing of suppressive subtractive hybridization products. Physiol Genomics, 22(1), 99-107. doi:00276.2004 [pii] 10.1152/physiolgenomics.00276.2004

Patel, O. V., Yamada, O., Kizaki, K., Takahashi, T., Imai, K., \& Hashizume, K. (2004). Quantitative analysis throughout pregnancy of placentomal and interplacentomal expression of pregnancy-associated glycoproteins- 1 and -9 in the cow. Mol Reprod Dev, 67(3), 257-263. doi:10.1002/mrd.20017

Pfaffl, M. W. (2001). A new mathematical model for relative quantification in real-time RT-PCR. Nucleic Acids Res, 29(9), e45.

Rexroad, C. E., Casida, L. E., \& Tyler, W. J. (1974). Crown-Rump Length of Fetuses in Purebred Holstein-Friesian Cows. J Dairy Sci, 57(3), 346-347.

Sasser, R. G., Ruder, C. A., Ivani, K. A., Butler, J. E. \& Hamilton, W. C. (1986). Detection of pregnancy by radioimmunoassay of a novel pregnancy-specific protein in serum of cows and a profile of serum concentrations during gestation. Biol Reprod, 35(4), 936-942.

Schönmuth, G. \& Löber, M. (2006). Beziehungen zwischen Körpergröße und Leistungen beim Rind. Züchtungskunde, 78(5), 324-335.

Szafranska, B., Panasiewicz, G., \& Majewska, M. (2006). Biodiversity of multiple Pregnancy-Associated Glycoprotein (PAG) family: gene cloning and chorionic protein purification in domestic and wild eutherians (Placentalia)--a review. Reprod Nutr Dev, 46(5), 481-502. doi:10.1051/rnd:2006034 r6510 [pii]

Szafranska, B., Xie, S., Green, J., \& Roberts, R. M. (1995). Porcine pregnancy-associated glycoproteins: new members of the aspartic proteinase gene family expressed in trophectoderm. Biol Reprod, 53(1), 21-28.

Telugu, B. P., Palmier, M. O., Van Doren, S. R., \& Green, J. A. (2010). An examination of the proteolytic activity for bovine pregnancy-associated glycoproteins 2 and 12 . Biol Chem, 391(2-3), 259-270. doi:10.1515/BC.2010.016

Telugu, B. P., Walker, A. M., \& Green, J. A. (2009). Characterization of the bovine pregnancy-associated glycoprotein gene family--analysis of gene sequences, regulatory regions within the promoter and expression of selected genes. BMC Genomics, 10, 185. doi:1471-2164-10-185 [pii] 10.1186/1471-2164-10-185

TierErzHaVerbG. (Zuletzt geändert durch Art. 3 Abs. 1 u. 3 G v. 30.6.2017). Gesetz zur Durchführung unionsrechtlicher Vorschriften über Verbote und Beschränkungen hinsichtlich des Handels mit bestimmten tierischen Erzeugnissen sowie zu Haltungs- und Abgabeverboten in bestimmten Fällen (Tiererzeugnisse-HandelsVerbotsgesetz - TierErzHaVerbG). 
Touzard, E., Reinaud, P., Dubois, O., Guyader-Joly, C., Humblot, P., Ponsart, C. (2013). Specific expression patterns and cell distribution of ancient and modern PAG in bovine placenta during pregnancy. Reproduction, 146(4), 347-362. doi:REP-130143 [pii] 10.1530/REP-13-0143

Wallace, R. M., Pohler, K. G., Smith, M. F., \& Green, J. A. (2015). Placental PAGs: gene origins, expression patterns, and use as markers of pregnancy. Reproduction, 149(3), R115-126. doi:149/3/R115 [pii] 10.1530/REP-14-0485

Weems, Y. S., Lammoglia, M. A., Vera-Avila, H. R., Randel, R. D., Sasser, R. G., \& Weems, C. W. (1998). Effects of luteinizing hormone (LH), PGE(2), 8-Epi-PGE(1), 8-Epi-PGF(2 alpha), trichosanthin and pregnancy specific protein $B$ (PSPB) on secretion of prostaglandin (PG)E (PGE) or F-2 alpha (PGF(2 alpha)) in vitro by corpora lutea $(\mathrm{CL})$ from nonpregnant and pregnant cows. Prostaglandins \& Other Lipid Mediators, 55(5-6), 359-376. doi:Doi 10.1016/S00906980(98)00030-6

Wooding, F. B., Roberts, R. M., \& Green, J. A. (2005). Light and electron microscope immunocytochemical studies of the distribution of pregnancy associated glycoproteins (PAGs) throughout pregnancy in the cow: possible functional implications. Placenta, 26(10), 807-827. doi:S0143-4004(04)00266-8 [pii] 10.1016/j.placenta.2004.10.014

Xie, S., Green, J., Bao, B., Beckers, J. F., Valdez, K. E., Hakami, L. (1997). Multiple pregnancy-associated glycoproteins are secreted by day 100 ovine placental tissue. Biol Reprod, 57(6), 1384-1393.

Xie, S., Green, J., Bixby, J. B., Szafranska, B., DeMartini, J. C., Hecht, S. (1997). The diversity and evolutionary relationships of the pregnancy-associated glycoproteins, an aspartic proteinase subfamily consisting of many trophoblastexpressed genes. Proc Natl Acad Sci U S A, 94(24), 12809-12816. 


\subsection{Diskussion}

Bis heute gibt es nur wenige detaillierte Studien über boPAG-Expressionsprofile über den gesamten Verlauf der Trächtigkeit. Hinzu kommt, dass die Vergleichbarkeit der Ergebnisse häufig nicht gegeben ist, da zumeist nur bestimmte Trächtigkeitstage untersucht wurden (Telugu et al., 2009; Touzard et al., 2013) und die Ergebnisse teilweise nicht übereinstimmen. Das Ziel der vorliegenden Studie war es daher, detaillierte mRNA-Expressionsprofile ausgewählter moderner (boPAG-1, -9, -21) und anzestraler (boPAG-2, -8, -10, -11, -12) PAG-Gene über den gesamten Verlauf der Trächtigkeit darzustellen. Diese können wichtige Hinweise für spätere Proteinanalysen liefern.

Im Gegensatz zu anderen Expressionsanalysen boviner PAG-Gene wurden für diese Experimente Kotyledonen auf einem kommerziellen Schlachthof gesammelt und nicht gezielt Tiere besamt und an bestimmten Testtagen geschlachtet, wodurch keine genauen Informationen über den Trächtigkeitsstatus der Tiere vorlagen. Das Alter der Feten wurde durch Bestimmung der Scheitel-Steiß-Länge ermittelt (Rexroad et al., 1974). Obwohl es sich dabei um ein Standardverfahren zur Ermittlung des Alters von Holstein-Friesian Feten handelt, ist es dennoch nur eine Annäherung. Zudem ist zu beachten, dass beispielsweise die Körperhöhe deutscher Holstein-Friesian Färsen allein von 1980 bis 1996 im Durchschnitt um 12 cm zugenommen hat (Schönmuth \& Löber, 2006). Es ist daher davon auszugehen, dass auch das fetale Wachstum beschleunigt ist. Dennoch konnten wir ähnliche Expressionsverläufe ermitteln, wie in Arbeiten, bei denen der tatsächliche Trächtigkeitstag bekannt war. Das zeigt, dass diese Methode, trotz des Zuchtfortschritts und der damit einhergehenden veränderten Körpergröße der Tiere (Schönmuth \& Löber, 2006) immer noch als adäquate Methode angesehen werden kann.

Bislang war davon auszugehen, dass etwa $10 \%$ der in Deutschland geschlachteten Milchkühe (Holstein-Friesian) tragend sind, davon der Großteil (ca. 90 \%) im mittleren bis letzten Trimester (Riehn et al., 2010; Riehn et al., 2011). Als Konsequenz ist seit dem 1. September 2017 eine Änderung des Tiererzeugnisse-Handels-Verbotsgesetzes (TierErzHaVerbG) in Kraft. Diese verbietet die Abgabe von im letzten Trächtigkeitsdrittel befindlichen Tieren zur Schlachtung (TierErzHaVerbG, § 4). Im Rahmen der Probensammlungen von graviden Rindern, u. a. für die vorliegende Studie, die seit Dezember 
2016 ein bis zweimal pro Monat auf Schlachthöfen stattfanden, konnte die Wirksamkeit der Gesetzesänderung beobachtet werden (Abbildung 3-3). Generell wurden weniger gravide Rinder am Schlachthof angeliefert. Weiterhin wurde bei Schlachthoffahrten nach dem 1. September 2017 lediglich ein Tier, das sich im letzten Trimester der Trächtigkeit befand, festgestellt. Weiterhin war ein leichter Rückgang von Tieren, die im zweiten Trimester zur Schlachtung angeliefert wurden, zu verzeichnen.

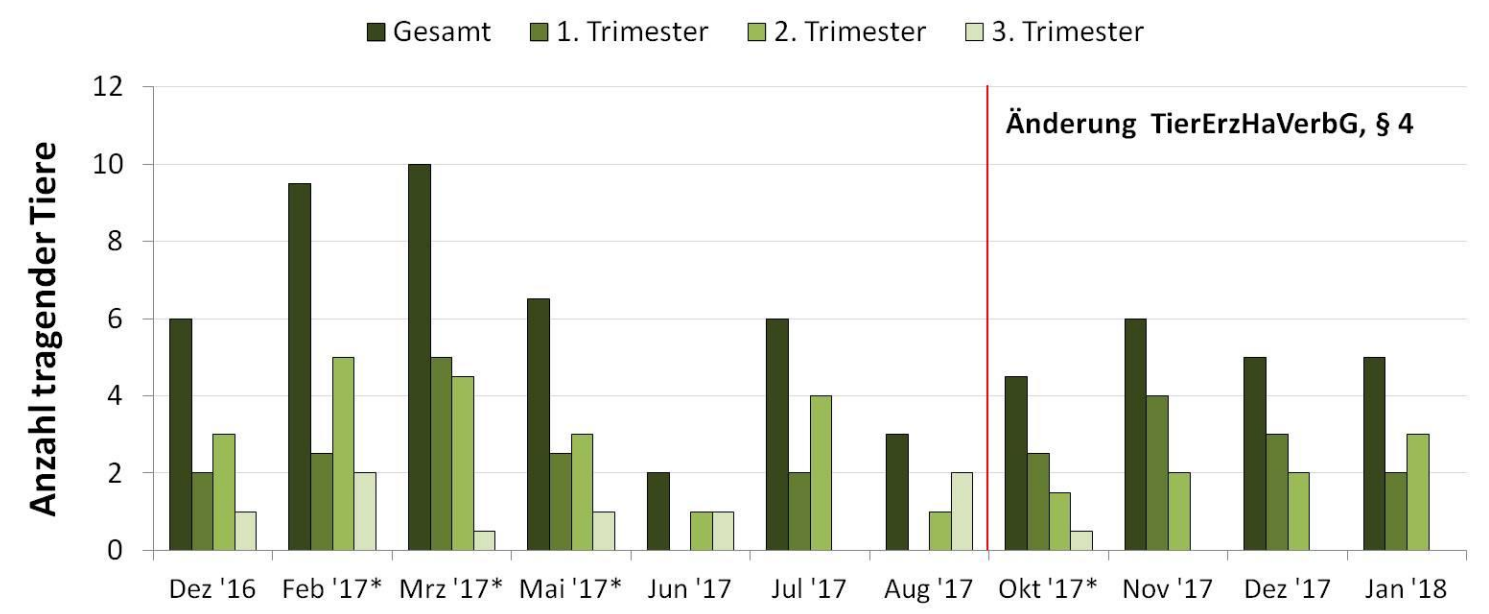

Datum der Probensammlung

*: Durchschnittliche Probenzahl von zwei Schlachthofbesuchen

Abbildung 3-3: Anlieferungszahlen von graviden Rindern am Schlachthof.

Es wurden insgesamt Kotyledonen von 23 trächtigen Kühen gesammelt und in drei verschiedene Trächtigkeitsabschnitte eingeteilt: frühe Trächtigkeit (20 - 90 Tage, $N=12$ ), mittlere Trächtigkeit (91 - 180 Tage, $N=11)$, späte Trächtigkeit (181 Tage Geburt, $N=1$ ). Die meisten Proben wurden aus Kotyledonen zwischen dem 70. und 110. Trächtigkeitstag entnommen. Die geringe Probenanzahl für die späte Trächtigkeit ist darauf zurückzuführen, dass zum einen seit Oktober 2017 weniger hochtragende Tiere zur Schlachtung angeliefert wurden. Zum anderen mussten teilweise einzelne oder sogar alle biologischen Replikate einer Probe, insbesondere von Trächtigkeiten ab Tag 150, von der Analyse ausgeschlossen werden, da zu unterschiedliche Expressionsmuster innerhalb der Replikate einer Probe ermittelt wurden oder die RNA-Qualität nicht ausreichend war. 
Grundsätzlich fiel auf, dass die RNA-Qualität von Proben in früheren Trächtigkeitsstadien besser war, als jene von Proben aus höheren Trächtigkeitsstadien. Das kann ein Ergebnis des größeren Zeitaufwandes bei der Probensammlung sein. Im Verlauf der Trächtigkeit unterliegen die Plazentome einem deutlichen Größenwachstum, wodurch auch die Verbindung zwischen maternalem Karunkel und fetaler Kotyledone stärker wird. Außerdem wurde je nach Größe der Plazentome entweder eine komplette Kotyledone als Replikat entnommen oder, in späten Trächtigkeiten, ein Stück aus jeder Kotyledone für die RNA-Isolation heraus geschnitten. Die Trennung des fetalen vom maternalen Gewebe und die Präparation des Probenmaterials sind daher aufwändiger und zeitintensiver, was zur schnelleren Degradation der RNA geführt haben könnte. Ein negativer Effekt der verstrichenen Zeit während der Probenentnahme und -bearbeitung auf die RNA-Integrität wurde bereits in früheren Studien festgestellt (Copois et al., 2007; Fajardy et al., 2009).

In der Plazenta gibt es eine Vielzahl unterschiedlicher Zelltypen, fetale und maternale Bereiche, sowie Regionen die Blut beider Individuen beinhalten (Mondon et al., 2005; Fajardy et al., 2009). Während der gesamten Trächtigkeit ist die Anzahl, sowie das Gewicht der Plazentome im trächtigen Uterushorn signifikant höher, als im nicht trächtigen Horn (Laven \& Peters, 2001), was ebenfalls auf eine unterschiedliche Zellzusammensetzung der Plazentome im tragenden bzw. nicht tragenden Uterushorn zurückzuführen sein könnte. Beispielsweise machen beim Rind binukleäre Zellen von der Implantation bis ein bzw. zwei Tage vor der Geburt 15 - 20 \% der Trophektodermzellen aus. Kurz vor der Geburt nimmt die Anzahl der BNCs drastisch ab (Wooding, 1983; Wooding et al., 1986). Nach Wooding \& Wathes (1980) sind 80 - 90 \% der BNCs von einkernigen Zellen umgeben, die keine Verbindung zu den Mikrovilli haben. Die restlichen 10 - 15 \% der BNCs bilden einen Teil der mikrovillären Verbindung. Die Migration der BNCs ist jedoch ein über die gesamte Trächtigkeit bestehender Prozess. Dieser wird dadurch verdeutlicht, dass eine stärkere Anhäufung von BNCs an der fetomaternalen Schnittstelle vorliegt (Lee et al., 1985; Wooding \& Burton, 2008), was vermutlich dazu führt, dass etwa 2 \% der Zellen im Uterusepithel zwei oder mehr Zellkerne aufweisen (Wooding \& Wathes, 1980). Dies führt sogar bei Replikaten des gleichen Individuums aufgrund der unterschiedlichen Zellzusammensetzung zu unterschiedli- 
chen Expressionsmustern. Da die Mehrzahl der bovinen PAGs in den binukleären Zellen der Plazenta lokalisiert ist und lediglich ein Teil im Trophektoderm exprimiert wird (Patel et al., 2004), ist es möglich, dass bei unterschiedlicher Zellzusammensetzung der Kotyledonen, die Expressionslevel in biologischen Replikaten differieren.

Patel et al. (2004) untersuchten die relative Expression von boPAG-1 und boPAG-9 während der Trächtigkeit in verschiedenen Plazentageweben. Sie zeigten am 30. Trächtigkeitstag in Choriongewebe eine signifikant höhere boPAG-9-Expression im Vergleich zu boPAG-1. Diese Beobachtung kann hier hinsichtlich einer höheren Expression bestätigt werden, auch wenn in der vorliegenden Studie kein signifikanter Expressionsunterschied nachgewiesen werden konnte. Anzumerken ist hierbei, dass in der vorliegenden Studie lediglich Kotyledonengewebe verwendet wurde, welches eine andere Zellzusammensetzung aufweist als das Chorion. Patel et al. (2004) gehen daher davon aus, dass boPAG-9 eine Funktion in der frühen Phase der Trächtigkeit, beispielsweise bei der Implantation und Plazentation, hat.

Weiterhin kann die von Touzard et al. (2013) beschriebene niedrigste boPAG-1 Expression an Tag 60 p. c., mit einem drastischen Anstieg bis Tag 80 p. c., bestätigt werden. Generell ist boPAG-1 in Phasen des fetalen und mammären Wachstums höher exprimiert. Dies lässt darauf schließen, dass es eine Rolle bei geburtsvorbereitenden Ereignissen spielt (Patel et al., 2004).

In einer älteren Studie von Telugu et al. (2009) wurde boPAG-2 als das am häufigsten vorkommende Transkript beschrieben. Auch wenn sich dieser Befund mit einer relativen Expressionsanalyse nicht bestätigt, zeigen auch die vorliegenden Daten in absoluten Zahlen eine deutlich höhere Expression von boPAG-2 im Vergleich zu den anderen untersuchten boPAG-Genen. Welche regulatorischen Mechanismen diesen Unterschied bewirken, konnte noch nicht geklärt werden. Telugu et al. (2009) beschrieben hoch konservierte prä-transkriptionale regulatorische Sequenzen innerhalb der PAGGenfamilie mit potentiellen Bindungsstellen für Transkriptionsfaktoren, die in die transkriptionale Regulation involviert sein könnten.

Die vorliegenden Ergebnisse zeigen, dass die relative Expression von boPAG-8 während der gesamten Trächtigkeit signifikant höher ist, als die anderer boPAG-Gene 
(Wiedemann et al., 2018b). Zu dem gleichen Ergebnis kamen auch schon Touzard et al. (2013). Außerdem konnte, wie bereits in den Ergebnissen von Telugu et al. (2009), eine signifikant höhere Expression von boPAG-8 und boPAG-11 in der frühen Trächtigkeit nachgewiesen werden. Beide Studien zeigen eine Abnahme der Expression von boPAG-8 und -11 im Verlauf der Trächtigkeit mit einem kurzen Anstieg um Tag 80. Einen konträren Verlauf zeigt boPAG-10. Dieses hat sein höchstes Expressionsniveau am Ende des zweiten bzw. Anfang des dritten Trimesters. Dennoch ist es das am niedrigsten exprimierte PAG der vorliegenden Studie. Grundsätzlich können mit der vorliegenden Arbeit die bisher bekannten Studien von Patel et al. (2004), Telugu et al. (2009) und Touzard et al. (2013) gestützt werden.

Wie bereits beschrieben, unterliegen PAG-Gene unterschiedlichen räumlich-zeitlichen Expressionsmustern. Anzestrale PAG-Gene werden hauptsächlich im Chorion der interkotyledonären Regionen exprimiert und weniger in den Kotyledonen. Im Gegensatz dazu werden moderne PAGs überwiegend in den Kotyledonen exprimiert (u. a. Patel et al., 2004; Touzard et al., 2013). Um diesen Unterschied besser herauszustellen, sollten für weitere Untersuchungen neben den Kotyledonen auch Proben der umliegenden Gewebe analysiert werden.

In Bezug auf die Expressionsverläufe ist anzunehmen, dass boPAG-Gene mit einer höheren Expression in der frühen Trächtigkeit (boPAG-8 und -11) vermutlich wichtige Faktoren bei der Plazentation sind. Touzard et al. (2013) wiesen darauf hin, dass boPAG-11 in den BNCs an der Chorionplatte lokalisiert ist. Damit ist es ideal positioniert, um als Brückenmolekül bei der Zell-Zell-Adhäsion zu agieren (Wooding et al., 2005; Wallace et al., 2015). Etwa ab dem 30. Trächtigkeitstag bilden sich die Kotyledonen aus (Schlafer et al., 2000). Die Entwicklung der Plazentome setzt sich über die ersten zwei bis drei Monate der Gravidiät fort. Obwohl der Trophoblast in seinem biologischen Verhalten stark reguliert ist, simuliert er aufgrund des Eindringens in die Uteruswand und der Uterusspiralarterien ein Malignom. Dieser Prozess ist zumindest teilweise abhängig von der regulierten Produktion von Proteasen, um die extrazelluläre Matrix abzubauen (Moll \& Lane, 1990). Anzestrale PAGs weisen alle Charakteristika von Aspartatproteasen auf (Xie et al., 1991; Guruprasad et al., 1996; Telugu et al., 2010), weshalb sie proteolytisch aktiv sein könnten. Diese Eigenschaft wird möglicher- 
weise genutzt, um eine Schutzfunktion für den Trophoblasten vor dem maternalen Immunsystem einzunehmen, indem sie für den Trophoblasten schädliche Moleküle oder Zellen zerstören (Wooding et al., 2005). Trotz zahlreicher Spekulationen ist die Funktion der PAGs weiterhin unklar. Durch die Charakterisierung der regulatorischen Mechanismen könnte dazu beigetragen werden, die boPAG-Expression besser zu verstehen. Mit Hilfe dieser Erkenntnisse wäre es möglich, Rückschlüsse über die genaue Funktion der PAGs während der Trächtigkeit zu ziehen.

Da die mRNA-Expression in gewissem Maße mit der Proteinmenge korreliert (Guo et al., 2008; Vogel \& Marcotte, 2012), ist davon auszugehen, dass aufgrund der höheren Expression auch eine höhere Konzentration von PAGs im maternalen Kreislauf vorliegt. Das macht speziell früh exprimierte PAGs, wie boPAG-8 oder boPAG-11 zu möglichen Indikatoren für eine frühzeitige Trächtigkeitsdiagnose beim Rind. 


\section{Allgemeine Diskussion}

Die Nutzung genetischer Marker hat sich in der Tierzucht als besonders hilfreich bei Merkmalen erwiesen, deren Erfassung schwierig oder teuer ist bzw. die erst im späteren Leben erfassbar sind (Davis \& DeNise, 1998).

Ein Beispiel hierfür sind Fruchtbarkeits- und Spermaqualitätsmerkmale, die erst nach der Pubertät bestimmt werden können. Grundvoraussetzung für die Gewährleistung des Reproduktionserfolges ist die kontinuierliche Überprüfung von Ejakulaten hinsichtlich ihrer Qualität. Diese unterliegt zahlreichen Einflussfaktoren, wie dem Alter und der Rasse der Eber (Borg et al., 1993; Bertani et al., 2002; Pizzi et al., 2005), sowie der Jahreszeit der Ejakulatgewinnung (Dörner \& Hühn, 1991; Suriyasomboon et al., 2005). In der vorliegenden Studie konnten signifikante Einflüsse auf das Vorkommen verschiedener morphologischer Veränderungen von Spermien in Ejakulaten von Besamungsebern nachgewiesen werden. Dazu zählt beispielsweise ein signifikanter Einfluss der Rasse $(p<0,05)$ auf das Vorkommen von Plasmatropfen beim Deutschen Edelschwein. Weiterhin stieg der Anteil pathomorpher Spermien in Ejakulaten mit zunehmendem Alter der Eber aller Rassen an (Jansen et al., 2017). Neben den Umwelteinflüssen konnte ein deutlicher Einzeltiereffekt auf die Inzidenz von Spermienanomalien ermittelt werden, der auf eine zusätzliche genetische Beeinflussung der Spermaqualität schließen lässt.

Der Einsatz und die stetige Verbesserung molekulargenetischer Techniken hat zur Identifizierung von zahlreichen Markern und Genen geführt, die im Zusammenhang mit der Tierproduktion bzw. der Reproduktion landwirtschaftlicher Nutztiere stehen (Lenffer et al., 2006; Fischer et al., 2015). Es sind jedoch nur wenige Informationen über die Kandidatengene verfügbar, die die Reproduktionsmerkmale von Ebern beeinflussen (Liu et al., 2017). Die Ergebnisse der vorliegenden Studie zeigen, dass das porzine DNAL4-Gen als Kandidatengen für die Spermaqualität angenommen werden kann (Wiedemann et al., 2018a). Es liegt auf SSC5p15 und kodiert für eine leichte Kette axonemaler Dyneine (Uhlmann et al., 2007). Ein SNP (g.1007A>G) im zweiten Intron des DNAL4-Gens ist aufgrund des Substitutionseffekts mit signifikant niedrigerer Motilität des nativen Ejakulats als auch nach 24- bzw. 48-stündiger Lagerung assoziiert. Da- 
bei zeigen sich für MOTUD signifikante Unterschiede zwischen allen Genotypen, bzw. zwischen den Genotypen AA und AG, sowie AA und GG für MOT1 und MOT2. Weiterhin liegt ein Einfluss von g.1007A>G auf das Vorkommen von Halsmittelstückdefekten vor. Dass auf dem porzinen Chromosom 5 bereits ein SNP im CD9-Gen (SSC5q25) mit Einfluss auf Spermienmotilität und das Vorhandensein von Plasmatropfen beschrieben wurde (Kaewmala et al., 2011), deutet darauf hin, dass SSC5 möglicherweise mit männlicher Fruchtbarkeit assoziiert ist (Wiedemann et al., 2018a).

Der Reproduktionserfolg ist jedoch nicht nur durch die männliche Seite determiniert, sondern zu gleichen Teilen von der weiblichen Fruchtbarkeit abhängig. Die Plazentation ist ein wichtiger Schritt für die Etablierung der Trächtigkeit, wodurch sich auch die Expression bestimmter Gene ändert bzw. diese zum ersten Mal exprimiert werden (Green et al., 2000; Ishiwata et al., 2003; Barreto et al., 2011). Eine Besonderheit bei Wiederkäuern ist das Auftreten von mehrkernigen Trophoblastenzellen (u. a. BNCs), die unter anderem trächtigkeitsassoziierte Glykoproteine durch Exozytose in den maternalen Blutkreislauf abgeben (Green et al., 2000). Die beim Rind bekannten 22 PAG-Gene werden in der Plazenta räumlich und zeitlich unterschiedlich exprimiert (Wallace et al., 2015). Die vorliegende Studie zeigte, dass in Kotyledonen die relative Expression von boPAG-8 während der gesamten Trächtigkeit signifikant höher ist, als die anderer boPAG-Gene. Außerdem konnte eine signifikant höhere Expression von boPAG-8 und boPAG-11 in der frühen Trächtigkeit nachgewiesen werden (Wiedemann et al., 2018b). Dies bestätigt die Ergebnisse früherer Untersuchungen (Telugu et al., 2009; Touzard et al., 2013) und deutet darauf hin, dass sie eine Funktion bei der Plazentation haben. Weiterhin könnten sie als mögliche Indikatoren für die frühe Trächtigkeitsdiagnose beim Rind dienen. 


\section{Zusammenfassung}

In der vorliegenden Dissertation werden zwei fortpflanzungsrelevante Themenkomplexe beim landwirtschaftlichen Nutztier behandelt.

Der erste Teil der Arbeit beschreibt die genetischen und umweltbedingten Einflussfaktoren auf die Qualität der Spermien in Ejakulaten von Besamungsebern.

Die erste Studie zu diesem Themenkomplex umfasste 1.543 Ejakulate von 57 Besamungsebern der Rassen Deutsches Edelschwein (DE), Deutsche Landrasse (DL), Pietrain sowie die Pietrain Linie db.77 ${ }^{\circledR}$ (BHZP77). Die Ejakulate wurden mikroskopisch analysiert und morphologisch veränderte Spermien in die Kategorien Kopfveränderungen, Kopfkappenveränderungen, Halsmittelstückdefekte, Schwanzveränderungen und Protoplasmatropfen eingeteilt. Ein signifikanter Effekt $(p<0,05)$ der Rasse auf das Vorhandensein von Protoplasmatropfen wurde bei DE nachgewiesen. Außerdem wurde ein Effekt der Zuchtsaison $(p<0,05)$ auf das Vorkommen verschiedener morphologischer Veränderungen ermittelt. Weiterhin zeigte sich ein Einfluss des Alters auf alle aufgezeichneten morphologischen Veränderungen $(p<0,05)$. Zusätzlich erfolgte eine Zuchtwertschätzung für die "Inzidenz der einzelnen Anomalien". Hierbei zeigte sich in allen Rassen ein deutlicher Unterschied der Zuchtwerte für alle Arten von Anomalien, wodurch ein genetischer Einfluss auf die Ejakulatqualität verdeutlicht wird.

Dynein, axonemal, light chain 4 (DNAL4) ist ein funktionelles Kandidatengen für Spermienmotilität, da es eine kleine Untereinheit der Dyneine kodiert. Der Flagellenschlag des Spermienschwanzes, der die Beweglichkeit der Spermien bedingt, wird durch die wechselnde Aktivierung und Inaktivierung von Dyneinmolekülen ausgelöst. In der gezeigten Studie wurde das porzine DNAL4-Gen an jeweils drei Besamungsebern mit hohen (> $68 \%$ ) oder niedrigen (<60\%) Spermamotilitäten resequenziert. Dabei wurden 23 SNPs ermittelt. Für diese wurden anschließend 82 Besamungseber der Rassen PI, DE und DL genotypisiert. Assoziationsanalysen zeigten, dass SNP g.1007A>G, im zweiten Intron des DNAL4-Gens, die Spermienmotilität signifikant reduziert (MOTUD -4.59\%; MOT1 -10.33\%; MOT2 -19.37\%). Der Genotyp AA zeigt dabei grundsätzlich eine höhere Motilität als die Genotypen AG und GG. Der durchschnittli- 
che Gensubstitutionseffekt (g.1007A>G) auf Halsmittelstückdefekte lag bei $0.71 \%$, die Genotypenwerte - dargestellt als LSmeans - waren 0.1 (AA) und 0.81 (AG).

Im zweiten Teil der Arbeit wird eine Expressionsanalyse boviner trächtigkeitsassoziierter Glykoproteine (pregnancy-associated glycoproteins, PAGs) in bovinen Kotyledonen beschrieben.

Mit der Entwicklung der Blastozyste aus der Morula und dem daraus entstehenden Embryo gehen drastische Veränderungen der Gen-Expression einher. Einige Gene, die nur im Trophektoderm transkribiert werden, werden während der Trächtigkeit damit zum ersten Mal aktiviert. Die Multigenfamilie der PAGs gehört zu einer Gruppe der Aspartatproteasen, die ausschließlich von Trophoblastenzellen in der Plazenta von Paarhufern exprimiert werden. Bei Boviden wurden bislang 22 PAG-Gene (boPAGs) mit verschiedenen räumlich-zeitlichen Expressionsmustern beschrieben. In der vorliegenden Arbeit wurden mRNA-Expressionsprofile für ausgewählte moderne (boPAG-1, -9, -21) und anzestrale (boPAG-2, -8, -10,-11,-12) bovine PAGs in Kotyledonengewebe erstellt. Die höchste Expression wurde für boPAG-8 ermittelt, die niedrigste für boPAG-10. Weiterhin stellte sich heraus, dass boPAG-8 und -11 in der frühen Trächtigkeit signifikant höher exprimiert werden, als in späteren Trächtigkeitsstadien. Die Charakterisierung von boPAG mRNA-Expressionsprofilen liefert wichtige Einblicke für spätere Proteinanalysen, die wertvoll für die Entwicklung neuer Trächtigkeitsnachweissysteme sind. 


\section{Summary}

This dissertation addresses two topics that are relevant for the reproduction of livestock. The first part of the thesis describes genetic and environmental factors influencing sperm quality in ejaculates of artificial insemination (Al) boars.

The first study of this complex comprised 1,543 ejaculates collected from 57 boars representing German Large White, German Landrace, Pietrain and Pietrain line $\mathrm{db} .77^{\circledR}$ (BHZP77). Ejaculates were analyzed microscopically and abnormal sperm cells were differentiated into varying morphological abnormalities such as abnormal heads, apical ridge defects of the acrosome, abnormal midpieces, abnormal tails and the presence of cytoplasmic droplets. A significant effect $(p<0.05)$ of breed on the presence of cytoplasmic droplets was found in German Large White boars. We detected significant effects $(p<0.05)$ of the breeding season on different anomalities. Furthermore the data showed an age dependent effect on all investigated anomalities ( $p<0.05)$. Additionally, the breeding value was calculated for the trait "incidence of individual anomalities". In this context there were clear differences between and within the evaluated breeds considering the different kinds of anomalities indicating a genetic effect on sperm quality.

Dynein, axonemal, light chain 4 (DNAL4) is a functional candidate gene for sperm motility as it encodes a small subunit of the dyneins. The flagellar beating of a spermatozoa's tail, and thus the sperm cell's motility, is caused by the varying activation and inactivation of dynein molecules. In the present study the porcine DNAL4 was resequenced using three artificial insemination (AI) boars each with high (>68\%) or low (<60\%) motility, thereby 23 SNP were detected. These were then genotyped for $82 \mathrm{Al}$ boars representing Pietrain, German Large White and German Landrace. Association analyzes propose that SNP g.1007A>G, located in the second intron of the DNAL4gene, reduces motility significantly (MOTUD -4.59\%; MOT1 -10.33\%; MOT2 -19.37\%). Genotype AA is always superior compared to genotypes AG and GG. The average effect of gene substitution ( $\mathrm{g} .1007 \mathrm{~A}>\mathrm{G}$ ) on abnormal midpiece ( $\mathrm{AM}$ ) was $0.71 \%$, the genotypic values - as expressed by LSmeans - were 0.1 (AA) and 0.81 (AG). 
The second part of the thesis describes an expression analysis of prengancy-associated glycoproteins (PAGs) in bovine cotyledons.

The development of the blastocyst from the morula and the resulting embryo is accompanied by severe changes in gene expression. Some genes that are transcribed only in the trophectoderm are activated for the first time during pregnancy. The multigene family of PAGs belongs to a group of aspartate proteases that are exclusively expressed by trophoblast cells in the placenta of even-toed ungulated species. In bovids, 22 PAG-genes (boPAGs) with different spatio-temporal expression patterns have been described. In the present study, mRNA expression profiles were determined for selected modern (boPAG-1, -9, -21) and ancestral (boPAG-2, -8, -10, -11, -12) bovine PAGs in cotyledon tissue. The highest expression was found for boPAG-8, the lowest for boPAG-10. Furthermore, it was found that boPAG-8 and -11 are significantly higher expressed in early gestation compared to later gestational stages. The characterization of boPAG mRNA-expression profiles provides important insights for future protein analyzes that are valuable for the development of new pregnancy detection systems. 


\section{Literaturverzeichnis}

Abu Hassan Abu, D., Franken, D. R., Hoffman, B. \& Henkel, R. (2012). Accurate sperm morphology assessment predicts sperm function. Andrologia, 44 Suppl 1, 571577.

Afzelius, B. (1959). Electron microscopy of the sperm tail; results obtained with a new fixative. J Biophys Biochem Cytol, 5(2), 269-278.

Aires, M., Dekagi, K., Dantzer, V. \& Yamada, A. (2014). Bovine placentome development during early pregnancy. In Méndez-Vilas, A.: Microscopy: advances in scientific research and education (Vol. 1, pp. 390-396): Formatex Research Center.

Banerjee, R., Liu, J., Beatty, W., Pelosof, L., Klemba, M. \& Goldberg, D. E. (2002). Four plasmepsins are active in the Plasmodium falciparum food vacuole, including a protease with an active-site histidine. Proc Natl Acad Sci U S A, 99(2), 990-995.

Barbato, O., Sousa, N. M., Klisch, K., Clerget, E., Debenedetti, A., Barile, V. L., Malfatti, A. \& Beckers, J. F. (2008). Isolation of new pregnancy-associated glycoproteins from water buffalo (Bubalus bubalis) placenta by Vicia villosa affinity chromatography. Res Vet Sci, 85(3), 457-466.

Barbato, O., Melo de Sousa, N., Barile, V. L., Canali, C. \& Beckers, J. F. (2013). Purification of pregnancy-associated glycoproteins from late-pregnancy Bubalus bubalis placentas and development of a radioimmunoassay for pregnancy diagnosis in water buffalo females. BMC Vet Res, 9, 89.

Barreto, R. S., Bressan, F. F., Oliveira, L. J., Pereira, F. T., Perecin, F., Ambrosio, C. E., Meirelles, F. V. \& Miglino, M. A. (2011). Gene expression in placentation of farm animals: an overview of gene function during development. Theriogenology, 76(4), 589-597.

Beckers, J. F., Wouters-Ballman, P. \& Ectors, F. (1988). Isolation and radioimmunoassay of a bovine pregnancy-specific protein. Theriogenology, 29(1), 219.

Beerda, B., Wyszynska-Koko, J., Te Pas, M. F., de Wit, A. A. \& Veerkamp, R. F. (2008). Expression profiles of genes regulating dairy cow fertility: recent findings, ongoing activities and future possibilities. Animal, 2(8), 1158-1167. 
Beriot, M., Tchimbou, A. F., Barbato, O., Beckers, J. F. \& de Sousa, N. M. (2014). Identification of pregnancy-associated glycoproteins and alpha-fetoprotein in fallow deer (Dama dama) placenta. Acta Vet Scand, 56(1), 4.

Berry, C., Humphreys, M. J., Matharu, P., Granger, R., Horrocks, P., Moon, R. P., Certa, U., Ridley, R. G., Bur, D. \& Kay, J. (1999). A distinct member of the aspartic proteinase gene family from the human malaria parasite Plasmodium falciparum. FEBS Lett, 447(2-3), 149-154.

Bertani, G. R., Scheid, I. R., Irgang, R., Barioni, W., Jr., Wentz, I. \& Afonso, S. B. (2002). Gonadal sperm reserve in purebred Landrace and Large White boars of high average daily gain. Theriogenology, 57(2), 859-867.

Blom, E. (1950). Interpretation of spermatic cytology in bulls. Fertil Steril, 1(3), 223238.

Blom, E. (1973). The ultrastructure of some characteristic sperm defects and a proposal for a new classification of the bull spermiogram. Nord Vet Med, 25(7), 383-391.

Boichard, D., Ducrocq, V., Croiseau, P. \& Fritz, S. (2016). Genomic selection in domestic animals: Principles, applications and perspectives. C R Biol, 339(7-8), 274-277.

Bonet, B., Briz, M. \& Fradera, A. (1991). The sperm quality and fertility of boars after two different ejaculation frequencies. Scientia Gerundensis, 17, 77-84.

Bonet, S. (1990). Immature and abberant spermatozoa in the ejaculate of Sus domesticus. Anim Reprod Sci, 22, 67-80.

Borg, K. E., Lunstra, D. D. \& Christenson, R. K. (1993). Semen characteristics, testicular size, and reproductive hormone concentrations in mature duroc, meishan, fengjing, and minzhu boars. Biol Reprod, 49(3), 515-521.

Briz, M. D., Bonet, S., Pinart, B., Egozcue, J. \& Camps, R. (1995). Comparative study of boar sperm coming from the caput, corpus, and cauda regions of the epididymis. J Androl, 16(2), 175-188.

Briz, M. D. \& Fàbrega, A. (2013). The Boar Spermatozoon. In Bonet, S., Casas, I., Holt, W. V. \& Yeste, M.: Boar Reproduction: Fundamentals and New Biotechnological Trends (Vol. 1). Heidelberg: Springer-Verlag.

Broekhuijse, M. L., Feitsma, H. \& Gadella, B. M. (2012). Artificial insemination in pigs: predicting male fertility. Vet $Q, 32(3-4), 151-157$. 
Buder, S. (2013). Einflussfaktoren auf die Spermaparameter bei Jungebern - eine Analyse der Daten des Referenzlabors IFN Schönow e. V. aus den Jahren 2001 bis 2011. Dissertation Tierärztliche Hochschule Hannover, Hannover.

Burgess, S. A., Walker, M. L., Sakakibara, H., Knight, P. J. \& Oiwa, K. (2003). Dynein structure and power stroke. Nature, 421(6924), 715-718.

Butler, J. E., Hamilton, W. C., Sasser, R. G., Ruder, C. A., Hass, G. M. \& Williams, R. J. (1982). Detection and partial characterization of two bovine pregnancy-specific proteins. Biol Reprod, 26(5), 925-933.

Capon, F., Allen, M. H., Ameen, M., Burden, A. D., Tillman, D., Barker, J. N. \& Trembath, R. C. (2004). A synonymous SNP of the corneodesmosin gene leads to increased mRNA stability and demonstrates association with psoriasis across diverse ethnic groups. Hum Mol Genet, 13(20), 2361-2368.

Cardullo, R. A. \& Baltz, J. M. (1991). Metabolic regulation in mammalian sperm: mitochondrial volume determines sperm length and flagellar beat frequency. Cell Motil Cytoskeleton, 19(3), 180-188.

Caşkurlu, T., Tasci, A. I., Samasti, M., Bayraktar, Z., Cek, M. \& Sevin, G. (1999). Immature germ cells in semen and their correlations with other semen parameters. Int Urol Nephrol, 31(3), 389-393.

Čeřovský, J., Frydrychová, S., Lustyková, A. \& Rozkot, M. (2005). Relation zwischen dem Gehalt an morphologisch abnormalen Spermien (MAS) im Ebersperma, der Jahreszeit und der Fertilität der künstlich besamten Sauen. In Wähner, M.: 11. Mitteldeutscher Schweine-Workshop in Bernburg (pp. 91-100). Bernburg: Verlag Hochschule Anhalt (FH).

Chen, X., Rosenfeld, C. S., Roberts, R. M. \& Green, J. A. (2001). An aspartic proteinase expressed in the yolk sac and neonatal stomach of the mouse. Biol Reprod, 65(4), 1092-1101.

Chenoweth, P. J. (2005). Genetic sperm defects. Theriogenology, 64(3), 457-468.

Chentouf, M., El Amiri, B., Sulon, J., Beckers, J. F., Kirschvink, N., Boulanouar, B. \& Bister, J. L. (2008). Pregnancy-associated glycoprotein secretion in North Moroccan goats. Reprod Domest Anim, 43(6), 696-700. 
Ciereszko, A., Ottobre, J. S. \& Glogowski, J. (2000). Effects of season and breed on sperm acrosin activity and semen quality of boars. Anim Reprod Sci, 64(1-2), 8996.

Claus, R. \& Weiler, U. (1985). Influence of light and photoperiodicity on pig prolificacy. J Reprod Fertil Suppl, 33, 185-197.

Colenbrander, B., Feitsma, H. \& Grooten, H. J. (1993). Optimizing semen production for artificial insemination in swine. J Reprod Fertil Suppl, 48, 207-215.

Cooper, D. N. (2010). Functional intronic polymorphisms: Buried treasure awaiting discovery within our genes. Hum Genomics, 4(5), 284-288.

Cooper, T. G. \& Yeung, C. H. (2000). Physiologie der Spermienreifung. In Nieschlag, E., Behre, H. M. \& Nieschlag, S.: Andrologie - Grundlagen und Klinik der reproduktiven Gesundheit des Mannes (Vol. 3). Berlin: Springer-Verlag.

Copois, V., Bibeau, F., Bascoul-Mollevi, C., Salvetat, N., Chalbos, P., Bareil, C., Candeil, L., Fraslon, C., Conseiller, E., Granci, V., Maziere, P., Kramar, A., Ychou, M., Pau, B., Martineau, P., Molina, F. \& Del Rio, M. (2007). Impact of RNA degradation on gene expression profiles: assessment of different methods to reliably determine RNA quality. J Biotechnol, 127(4), 549-559.

Das, M., Mukhopadhyay, P. K. \& Chowdhury, M. (1994). Carbohydrate-binding profile of a pregnancy-associated rat uterine glycoprotein. Mol Cell Biochem, 137(2), 91-99.

Davies, D. R. (1990). The structure and function of the aspartic proteinases. Annu Rev Biophys Biophys Chem, 19, 189-215.

Davis, G. P. \& DeNise, S. K. (1998). The impact of genetic markers on selection. J Anim Sci, 76(9), 2331-2339.

de Sousa, N. M., Garbayo, J. M., Figueiredo, J. R., Sulon, J., Goncalves, P. B. \& Beckers, J. F. (1999). Pregnancy-associated glycoprotein and progesterone profiles during pregnancy and postpartum in native goats from the north-east of Brazil. Small Rumin Res, 32(1999), 137-147.

de Sousa, N. M., Remy, B., El Amiri, B., De Figueiredo, J. R., Banga-Mboko, H., Dias Goncalves, P. B. \& Beckers, J. F. (2002). Characterization of pregnancyassociated glycoproteins extracted from zebu (Bos indicus) placentas removed at different gestational periods. Reprod Nutr Dev, 42(3), 227-241. 
de Sousa, N. M., Ayad, A., Beckers, J. F. \& Gajewski, Z. (2006). Pregnancy-associated glycoproteins (PAG) as pregnancy markers in the ruminants. J Physiol Pharmacol, 57 Suppl 8, 153-171.

Diniz, D. B., Lopes, M. S., Broekhuijse, M. L., Lopes, P. S., Harlizius, B., Guimaraes, S. E., Duijvesteijn, N., Knol, E. F. \& Silva, F. F. (2014). A genome-wide association study reveals a novel candidate gene for sperm motility in pigs. Anim Reprod Sci, 151(3-4), 201-207.

Dörner, E. \& Hühn, U. (1991). Zum Vorkommen von Spermaanomalien bei rassedifferenten Besamungsebern im Verlaufe eines Jahres. Arch Tierzucht, 34, 391-399.

Drew, M. L., Alexander, B. M. \& Sasser, R. G. (1995). Pregnancy determination by use of pregnancy-specific protein B radioimmunoassay in llamas. J Am Vet Med Assoc, 207(2), 217-219.

Fajardy, I., Moitrot, E., Vambergue, A., Vandersippe-Millot, M., Deruelle, P. \& Rousseaux, J. (2009). Time course analysis of RNA stability in human placenta. BMC Mol Biol, 10, 21.

Fawcett, D. W. (1975). The mammalian spermatozoon. Dev Biol, 44(2), 394-436.

Fischer, D., Laiho, A., Gyenesei, A. \& Sironen, A. (2015). Identification of ReproductionRelated Gene Polymorphisms Using Whole Transcriptome Sequencing in the Large White Pig Population. G3 (Bethesda), 5(7), 1351-1360.

Gan, X., Xie, S., Green, J. A. \& Roberts, R. M. (1997). Identification of transcripts for pregnancy-associated glycoprotein (PAG) in carnivora and perissodactyla. 30th annual meeting Portland, Oregon, USA. Biol Reprod, 56(suppl. 1), 431.

Garbayo, J. M., Remy, B., Alabart, J. L., Folch, J., Wattiez, R., Falmagne, P. \& Beckers, J. F. (1998). Isolation and partial characterization of a pregnancy-associated glycoprotein family from the goat placenta. Biol Reprod, 58(1), 109-115.

Gingeras, T. R. (2009). Implications of chimaeric non-co-linear transcripts. Nature, 461(7261), 206-211.

Green, J. A., Xie, S., Gan, X. \& Roberts, R. M. (1998a). An aspartic proteinase expressed in the equine placenta. Adv Exp Med Biol, 436, 163-167.

Green, J. A., Xie, S. \& Roberts, R. M. (1998b). Pepsin-related molecules secreted by trophoblast. Rev Reprod, 3(1), 62-69. 
Green, J. A., Xie, S., Szafranska, B., Gan, X., Newman, A. G., McDowell, K. \& Roberts, R. M. (1999). Identification of a new aspartic proteinase expressed by the outer chorionic cell layer of the equine placenta. Biol Reprod, 60(5), 1069-1077.

Green, J. A., Xie, S., Quan, X., Bao, B., Gan, X., Mathialagan, N., Beckers, J. F. \& Roberts, R. M. (2000). Pregnancy-associated bovine and ovine glycoproteins exhibit spatially and temporally distinct expression patterns during pregnancy. Biol Reprod, 62(6), 1624-1631.

Green, J. A., Parks, T. E., Avalle, M. P., Telugu, B. P., McLain, A. L., Peterson, A. J., McMillan, W., Mathialagan, N., Hook, R. R., Xie, S. \& Roberts, R. M. (2005). The establishment of an ELISA for the detection of pregnancy-associated glycoproteins (PAGs) in the serum of pregnant cows and heifers. Theriogenology, 63(5), 1481-1503.

Gunawan, A., Kaewmala, K., Uddin, M. J., Cinar, M. U., Tesfaye, D., Phatsara, C., Tholen, E., Looft, C. \& Schellander, K. (2011). Association study and expression analysis of porcine ESR1 as a candidate gene for boar fertility and sperm quality. Anim Reprod Sci, 128(1-4), 11-21.

Gunawan, A., Cinar, M. U., Uddin, M. J., Kaewmala, K., Tesfaye, D., Phatsara, C., Tholen, E., Looft, C. \& Schellander, K. (2012). Investigation on association and expression of ESR2 as a candidate gene for boar sperm quality and fertility. Reprod Domest Anim, 47(5), 782-790.

Guo, Y., Xiao, P., Lei, S., Deng, F., Xiao, G. G., Liu, Y., Chen, X., Li, L., Wu, S., Chen, Y., Jiang, H., Tan, L., Xie, J., Zhu, X., Liang, S. \& Deng, H. (2008). How is mRNA expression predictive for protein expression? A correlation study on human circulating monocytes. Acta Biochim Biophys Sin (Shanghai), 40(5), 426-436.

Guruprasad, K., Blundell, T. L., Xie, S., Green, J., Szafranska, B., Nagel, R. J., McDowell, K., Baker, C. B. \& Roberts, R. M. (1996). Comparative modelling and analysis of amino acid substitutions suggests that the family of pregnancy-associated glycoproteins includes both active and inactive aspartic proteinases. Protein Eng, 9(10), 849-856.

Haidl, G., Becker, A. \& Henkel, R. (1991). Poor development of outer dense fibers as a major cause of tail abnormalities in the spermatozoa of asthenoteratozoospermic men. Hum Reprod, 6(10), 1431-1438. 
Harris, T., Marquez, B., Suarez, S. \& Schimenti, J. (2007). Sperm motility defects and infertility in male mice with a mutation in Nsun7, a member of the Sun domaincontaining family of putative RNA methyltransferases. Biol Reprod, 77(2), 376382.

Hashizume, K., Ushizawa, K., Patel, O. V., Kizaki, K., Imai, K., Yamada, O., Nakano, H. \& Takahashi, T. (2007). Gene expression and maintenance of pregnancy in bovine: roles of trophoblastic binucleate cell-specific molecules. Reprod Fertil Dev, 19(1), 79-90.

Hashizume, K. (2007). Analysis of uteroplacental-specific molecules and their functions during implantation and placentation in the bovine. J Reprod Dev, 53(1), 1-11.

Hook, P. \& Vallee, R. B. (2006). The dynein family at a glance. J Cell Sci, 119(Pt 21), 4369-4371.

Huang, F., Cockrell, D. C., Stephenson, T. R., Noyes, J. H. \& Sasser, R. G. (1999). Isolation, purification, and characterization of pregnancy-specific protein $B$ from elk and moose placenta. Biol Reprod, 61(4), 1056-1061.

Hughes, A. L., Green, J. A., Garbayo, J. M. \& Roberts, R. M. (2000). Adaptive diversification within a large family of recently duplicated, placentally expressed genes. Proc Natl Acad Sci U S A, 97(7), 3319-3323.

Hughes, A. L., Green, J. A., Piontkivska, H. \& Roberts, R. M. (2003). Aspartic proteinase phylogeny and the origin of pregnancy-associated glycoproteins. Mol Biol Evol, 20(11), 1940-1945.

Inaba, K. (2003). Molecular architecture of the sperm flagella: molecules for motility and signaling. Zoolog Sci, 20(9), 1043-1056.

Inaba, K. (2011). Sperm flagella: comparative and phylogenetic perspectives of protein components. Mol Hum Reprod, 17(8), 524-538.

Ishiwata, H., Katsuma, S., Kizaki, K., Patel, O. V., Nakano, H., Takahashi, T., Imai, K., Hirasawa, A., Shiojima, S., Ikawa, H., Suzuki, Y., Tsujimoto, G., Izaike, Y., Todoroki, J. \& Hashizume, K. (2003). Characterization of gene expression profiles in early bovine pregnancy using a custom cDNA microarray. Mol Reprod Dev, 65(1), 9-18. 
Jansen, S., Sharifi, A. R., Knorr, C. \& Wiedemann, I. (2017). Analyse von morphologisch veränderten Spermien in Ejakulaten von Besamungsebern. Züchtungskunde, 89(4), 300-310.

Kaewmala, K., Uddin, M. J., Cinar, M. U., Grosse-Brinkhaus, C., Jonas, E., Tesfaye, D., Phatsara, C., Tholen, E., Looft, C. \& Schellander, K. (2011). Association study and expression analysis of CD9 as candidate gene for boar sperm quality and fertility traits. Anim Reprod Sci, 125(1-4), 170-179.

Kawecka, M., Pietruszka, A., Jacyno, E., Czarnecki, P. \& Kamyczek, M. (2008). Quality of semen of young boars of the breeds Pietrain and Duroc and their reciprocal crossbreds. Arch Tierzucht, 51(1), 42-54.

Kennedy, B. W. \& Wilkins, J. N. (1984). Boar, breed and environmental factors influencing semen characteristics of boars used in artificial insemination. Can. J. Anim. Sci., 64, 833-843.

Kiewisz, J., Sousa, N. M., Beckers, J. F., Vervaecke, H., Panasiewicz, G. \& Szafranska, B. (2008). Isolation of pregnancy-associated glycoproteins from placenta of the American bison (Bison bison) at first half of pregnancy. Gen Comp Endocrinol, 155(1), 164-175.

Kiewisz, J., Melo de Sousa, N., Beckers, J. F., Panasiewicz, G., Gizejewski, Z. \& Szafranska, B. (2009). Identification of multiple pregnancy-associated glycoproteins (PAGs) purified from the European bison (Eb; Bison bonasus L.) placentas. Anim Reprod Sci, 112(3-4), 229-250.

Kimchi-Sarfaty, C., Oh, J. M., Kim, I. W., Sauna, Z. E., Calcagno, A. M., Ambudkar, S. V. \& Gottesman, M. M. (2007). A "silent" polymorphism in the MDR1 gene changes substrate specificity. Science, 315(5811), 525-528.

King, G. J., Atkinson, B. A. \& Robertson, H. A. (1979). Development of the bovine placentome during the second month of gestation. J Reprod Fertil, 55(1), 173180.

King, G. J. (1993). Comparative placentation in ungulates. J Exp Zool, 266(6), 588-602.

Klisch, K., De Sousa, N. M., Beckers, J. F., Leiser, R. \& Pich, A. (2005). Pregnancy associated glycoprotein-1, $-6,-7$, and -17 are major products of bovine binucleate trophoblast giant cells at midpregnancy. Mol Reprod Dev, 71(4), 453-460. 
Knox, R. V. (2003). The anatomy \& Physiology of Sperm Production in Boars. Abgerufen am 27.08.2018, von http://www.ansci.wisc.edu/jjp1/pig_case/html/library/ boara\&p.pdf

Koshi, K., Suzuki, Y., Nakaya, Y., Imai, K., Hosoe, M., Takahashi, T., Kizaki, K., Miyazawa, T. \& Hashizume, K. (2012). Bovine trophoblastic cell differentiation and binucleation involves enhanced endogenous retrovirus element expression. Reprod Biol Endocrinol, 10, 41.

Kuster, C. \& Althouse, G. C. (2007). Reproductive Physiology and Endocrinology of Boars. In Youngquist, R. S. \& Threlfall, W. R.: Current Therapy in Large Animal Theriogenology (Vol. 2, pp. 717-721). St. Louis: Saunders Elsevier.

Kwan, T., Benovoy, D., Dias, C., Gurd, S., Provencher, C., Beaulieu, P., Hudson, T. J., Sladek, R. \& Majewski, J. (2008). Genome-wide analysis of transcript isoform variation in humans. Nature Genet, 40(2), 225-231.

Laven, R. A. \& Peters, A. R. (2001). Gross morphometry of the bovine placentome during gestation. Reprod Domest Anim, 36(6), 289-296.

Lee, C. S., Gogolin-Ewens, K., White, T. R. \& Brandon, M. R. (1985). Studies on the distribution of binucleate cells in the placenta of the sheep with a monoclonal antibody SBU-3. J Anat, 140 ( Pt 4), 565-576.

Lenffer, J., Nicholas, F. W., Castle, K., Rao, A., Gregory, S., Poidinger, M., Mailman, M. D. \& Ranganathan, S. (2006). OMIA (Online Mendelian Inheritance in Animals): an enhanced platform and integration into the Entrez search interface at NCBI. Nucleic Acids Res, 34(Database issue), D599-601.

Lin, C. L., Ponsuksili, S., Tholen, E., Jennen, D. G., Schellander, K. \& Wimmers, K. (2006). Candidate gene markers for sperm quality and fertility of boar. Anim Reprod Sci, 92(3-4), 349-363.

Lindemann, C. B. \& Lesich, K. A. (2010). Flagellar and ciliary beating: the proven and the possible. J Cell Sci, 123(Pt 4), 519-528.

Lipenský, J., Lustyková, A. \& Čeřovský, J. (2010). Effect of season on boar sperm morphology. J. Cent. Eur. Agric., 11(4), 465-468.

Liu, L., Shuai, Y., Rui, C., Xiaoyan, L. \& Chuanying, P. (2017). A novel synonymous SNP (A47A) of the TMEM95 gene is significantly associated with the reproductive traits related to testis in male piglets. Arch Tierzucht, 60, 235-241. 
Lopez Rodriguez, A., Van Soom, A., Arsenakis, I. \& Maes, D. (2017). Boar management and semen handling factors affect the quality of boar extended semen. Porcine Health Manag, 3, 15.

Love, C. C. (2011). Relationship between sperm motility, morphology and the fertility of stallions. Theriogenology, 76(3), 547-557.

Majewska, M., Panasiewicz, G. \& Szafranska, B. (2011). Pregnancy-associated glycoprotein (PAG) family localized in chorionic cells within the epitheliochorial/diffuse placenta of the alpaca (Lama pacos). Acta Histochem, 113(5), 570-577.

Majewska, M., Panasiewicz, G. \& Szafranska, B. (2013). Expression of pregnancyassociated glycoprotein family in the epitheliochorial placenta of two Camelidae species (C. dromedarius and C. bactrianus). Acta Histochem, 115(7), 669-676.

McPherson, F. J., Nielsen, S. G. \& Chenoweth, P. J. (2014). Semen effects on insemination outcomes in sows. Anim Reprod Sci, 151(1-2), 28-33.

Menon, A. G., Barkema, H. W., Wilde, R., Kastelic, J. P. \& Thundathil, J. C. (2011). Associations between sperm abnormalities, breed, age, and scrotal circumference in beef bulls. Can J Vet Res, 75(4), 241-247.

Meuwissen, T. H., Hayes, B. J. \& Goddard, M. E. (2001). Prediction of total genetic value using genome-wide dense marker maps. Genetics, 157(4), 1819-1829.

Meuwissen, T. H. E. (2009). Accuracy of breeding values of 'unrelated' individuals predicted by dense SNP genotyping. Genetics Sel Evol, 41.

Miki, K., Qu, W., Goulding, E. H., Willis, W. D., Bunch, D. O., Strader, L. F., Perreault, S. D., Eddy, E. M. \& O'Brien, D. A. (2004). Glyceraldehyde 3-phosphate dehydrogenase-S, a sperm-specific glycolytic enzyme, is required for sperm motility and male fertility. Proc Natl Acad Sci U S A, 101(47), 16501-16506.

Mohri, H., Inaba, K., Ishijima, S. \& Baba, S. A. (2012). Tubulin-dynein system in flagellar and ciliary movement. Proc Jpn Acad Ser B Phys Biol Sci, 88(8), 397-415.

Moll, U. M. \& Lane, B. L. (1990). Proteolytic activity of first trimester human placenta: localization of interstitial collagenase in villous and extravillous trophoblast. Histochemistry, 94(5), 555-560. 
Mondon, F., Mignot, T. M., Rebourcet, R., Jammes, H., Danan, J. L., Ferre, F. \& Vaiman, D. (2005). Profiling of oxygen-modulated gene expression in early human placenta by systematic sequencing of suppressive subtractive hybridization products. Physiol Genomics, 22(1), 99-107.

National Center for Biotechnology Information (NCBI). (2014). PREDICTED: Lipotes vexillifer pregnancy-associated glycoprotein 2-like (LOC103088571), mRNA. from National Center for Biotechnology Information, U.S. National Library of Medicine

National Center for Biotechnology Information (NCBI). (2015). PREDICTED: Orcinus orca pregnancy-associated glycoprotein 2-like (LOC101270677), mRNA. from National Center for Biotechnology Information, U.S. National Library of Medicine

Oh, S. H., See, M. T., Long, T. E. \& Galvin, J. M. (2006). Genetic parameters for various random regression models to describe total sperm cells per ejaculate over the reproductive lifetime of boars. J Anim Sci, 84(3), 538-545.

Ombelet, W., Menkveld, R., Kruger, T. F. \& Steeno, O. (1995). Sperm morphology assessment: historical review in relation to fertility. Hum Reprod Update, 1(6), 543-557.

Osborn, D. A., Beckers, J. F., Sulon, J., Gassett, J. W., Muller, L. I., Murphy, B. P., Miller, K. V. \& Marchinton, R. L. (1996). Use of glycoprotein assays of pregnancy diagnosis in white-tailed deer. J. Wildl. Manage, 60(2), 388-393.

Patel, O. V., Yamada, O., Kizaki, K., Takahashi, T., Imai, K. \& Hashizume, K. (2004). Quantitative analysis throughout pregnancy of placentomal and interplacentomal expression of pregnancy-associated glycoproteins- 1 and -9 in the cow. Mol Reprod Dev, 67(3), 257-263.

Petrocelli, H., Batista, C. \& Gosalvez, J. (2015). Seasonal variation in sperm characteristics of boars in southern Uruguay. R. Bras. Zootec., 44(1), 1-7.

Pizzi, F., Gliozzi T. M., Aletti B., Parodi L., Zaniboni L., Maldjian A. \& Cerolini S. (2005). Study of semen quality parameters in relation to genetic line and age of the boar. Theriogenology/Abstracts, 63(2), 493-494. 
Pohler, K. G., Geary, T. W., Johnson, C. L., Atkins, J. A., Jinks, E. M., Busch, D. C., Green, J. A., MacNeil, M. D. \& Smith, M. F. (2013). Circulating bovine pregnancy associated glycoproteins are associated with late embryonic/fetal survival but not ovulatory follicle size in suckled beef cows. J Anim Sci, 91(9), 4158-4167.

Pruneda, A., Pinart, E., Dolors Briz, M., Sancho, S., Garcia-Gil, N., Badia, E., Kadar, E., Bassols, J., Bussalleu, E., Yeste, M. \& Bonet, S. (2005). Effects of a high semencollection frequency on the quality of sperm from ejaculates and from six epididymal regions in boars. Theriogenology, 63(8), 2219-2232.

Reese, S. T., Pereira, M. C., Vasconcelos, J. L. M., Smith, M. F., Green, J. A., Geary, T. W., Peres, R. F. G., Perry, G. A. \& Pohler, K. G. (2016). Markers of pregnancy: how early can we detect pregnancies in cattle using pregnancy-associated glycoproteins (PAGs) and microRNAs? Anim Reprod, 13(3), 200-208.

Rexroad, C. E., Casida, L. E. \& Tyler, W. J. (1974). Crown-Rump Length of Fetuses in Purebred Holstein-Friesian Cows. J Dairy Sci, 57(3), 346-347.

Riehn, K., Domel, G., Einspanier, A., Gottschalk, J., Hildebrandt, G., Luy, J. \& Lücker, E. (2010). Schlachtung gravider Rinder - ethische und rechtliche Aspekte. Fleischwirtschaft, 90(8), 100-106.

Riehn, K., Domel, G., Einspanier, A., Gottschalk, J., Lochmann, G., Hildebrandt, G., Luy, J. \& Lücker, E. (2011). Schlachtung gravider Rinder - Aspekte der Ethik und des gesundheitlichen Verbraucherschutzes. Tierarztl Umschau, 66(10), 391-405.

Ropstad, E., Veiberg, V., Sakkinen, H., Dahl, E., Kindahl, H., Holand, O., Beckers, J. F. \& Eloranta, E. (2005). Endocrinology of pregnancy and early pregnancy detection by reproductive hormones in reindeer (Rangifer tarandus tarandus). Theriogenology, 63(6), 1775-1788.

Rovan, E. (2001). Biochemie der Spermatozoa. In Busch, W. \& Holzmann, A.: Veterinärmedizinische Andrologie (Vol. 1. Auflage, pp. 23-54). Stuttgart: Schattauer Verlag.

Sale, W. S. \& Satir, P. (1977). Direction of active sliding of microtubules in Tetrahymena cilia. Proc Natl Acad Sci U S A, 74(5), 2045-2049.

Samore, A. B. \& Fontanesi, L. (2016). Genomic selection in pigs: state of the art and perspectives. Ital. J. Anim. Sci., 15(2), 211-232. 
Sancho, S., Pinart, E., Briz, M., Garcia-Gil, N., Badia, E., Bassols, J., Kadar, E., Pruneda, A., Bussalleu, E., Yeste, M., Coll, M. G. \& Bonet, S. (2004). Semen quality of postpubertal boars during increasing and decreasing natural photoperiods. Theriogenology, 62(7), 1271-1282.

Sasser, R. G., Ruder, C. A., Ivani, K. A., Butler, J. E. \& Hamilton, W. C. (1986). Detection of pregnancy by radioimmunoassay of a novel pregnancy-specific protein in serum of cows and a profile of serum concentrations during gestation. Biol Reprod, 35(4), 936-942.

Schlafer, D. H., Fisher, P. J. \& Davies, C. J. (2000). The bovine placenta before and after birth: placental development and function in health and disease. Anim Reprod Sci, 60-61, 145-160.

Schönmuth, G. \& Löber, M. (2006). Beziehungen zwischen Körpergröße und Leistungen beim Rind. Züchtungskunde, 78(5), 324-335.

Schülke, B. (1991). Grundstruktur der Spermienzelle und Biochemie des Spermas. In Busch, W., Löhle, K. \& Peter, W.: Künstliche Besamung bei Nutztieren (Vol. 2. Auflage, pp. 209-237). Jena: Gustav Fischer Verlag.

Shingyoji, C. (2013). Measuring the regulation of dynein activity during flagellar motility. Methods Enzymol, 524, 147-169.

Sironen, A., Uimari, P., Nagy, S., Paku, S., Andersson, M. \& Vilkki, J. (2010). Knobbed acrosome defect is associated with a region containing the genes STK17b and HECW2 on porcine chromosome 15. BMC Genomics, 11, 699.

Sironen, A., Uimari, P., Venhoranta, H., Andersson, M. \& Vilkki, J. (2011). An exonic insertion within Tex14 gene causes spermatogenic arrest in pigs. BMC Genomics, 12, 591.

Sironen, A. I., Andersson, M., Uimari, P. \& Vilkki, J. (2002). Mapping of an immotile short tail sperm defect in the Finnish Yorkshire on porcine Chromosome 16. Mamm Genome, 13(1), 45-49.

Smital, J., Wolf, J. \& De Sousa, L. L. (2005). Estimation of genetic parameters of semen characteristics and reproductive traits in Al boars. Animal Reproduction Science, 86(1-2), 119-130. 
Summers, K. E. \& Gibbons, I. R. (1971). Adenosine triphosphate-induced sliding of tubules in trypsin-treated flagella of sea-urchin sperm. Proc Natl Acad Sci U S A, 68(12), 3092-3096.

Suriyasomboon, A., Lundeheim, N., Kunavongkrit, A. \& Einarsson, S. (2005). Effect of temperature and humidity on sperm morphology in duroc boars under different housing systems in Thailand. J Vet Med Sci, 67(8), 777-785.

Syring, C. (2008). Einfluss von Jahreszeit, Rasse und Alter auf die Samenqualität beim Eber. Dissertation Universität Zürich, Zürich.

Szafranska, B., Xie, S., Green, J. \& Roberts, R. M. (1995). Porcine pregnancy-associated glycoproteins: new members of the aspartic proteinase gene family expressed in trophectoderm. Biol Reprod, 53(1), 21-28.

Szafranska, B., Panasiewicz, G. \& Majewska, M. (2006). Biodiversity of multiple Pregnancy-Associated Glycoprotein (PAG) family: gene cloning and chorionic protein purification in domestic and wild eutherians (Placentalia)--a review. Reprod Nutr Dev, 46(5), 481-502.

Szostak, B. \& Burys, L. (2011). Effect of breed and age on the morphology of A.I. boars spermatozoa. Ann. Univ. Mariae Curie Sklodowska Sect. EE Zootech., XXIX(2), 44-51.

Tang, J. \& Wong, R. N. (1987). Evolution in the structure and function of aspartic proteases. J Cell Biochem, 33(1), 53-63.

Tang, W. J., Bell, C. W., Sale, W. S. \& Gibbons, I. R. (1982). Structure of the dynein-1 outer arm in sea urchin sperm flagella. I. Analysis by separation of subunits. $J$ Biol Chem, 257(1), 508-515.

Tardif, S., Laforest, J. P., Cormier, N. \& Bailey, J. L. (1999). The importance of porcine sperm parameters on fertility in vivo. Theriogenology, 52(3), 447-459.

Telugu, B. P., Walker, A. M. \& Green, J. A. (2009). Characterization of the bovine pregnancy-associated glycoprotein gene family--analysis of gene sequences, regulatory regions within the promoter and expression of selected genes. $B M C$ Genomics, 10, 185.

Telugu, B. P., Palmier, M. O., Van Doren, S. R. \& Green, J. A. (2010). An examination of the proteolytic activity for bovine pregnancy-associated glycoproteins 2 and 12 . Biol Chem, 391(2-3), 259-270. 
TierErzHaVerbG. (Zuletzt geändert durch Art. 3 Abs. 1 u. 3 G v. 30.6.2017). Gesetz zur Durchführung unionsrechtlicher Vorschriften über Verbote und Beschränkungen hinsichtlich des Handels mit bestimmten tierischen Erzeugnissen sowie zu Haltungs- und Abgabeverboten in bestimmten Fällen (Tiererzeugnisse-Handels-Verbotsgesetz - TierErzHaVerbG).

Touzard, E., Reinaud, P., Dubois, O., Guyader-Joly, C., Humblot, P., Ponsart, C. \& Charpigny, G. (2013). Specific expression patterns and cell distribution of ancient and modern PAG in bovine placenta during pregnancy. Reproduction, 146(4), 347-362.

Turner, R. M. (2003). Tales from the tail: what do we really know about sperm motility? J Androl, 24(6), 790-803.

Uhlmann, B., Kuiper, H., Distl, O. \& Leeb, T. (2007). Molecular characterization of the porcine DNAL4 gene. Arch Tierzucht, 50(3), 267-272.

Vogel, C. \& Marcotte, E. M. (2012). Insights into the regulation of protein abundance from proteomic and transcriptomic analyses. Nat Rev Genet, 13(4), 227-232.

Waberski, D. \& Petrunkina, A. M. (2007). Arbeits- und Untersuchungsmethoden. In Busch, W. \& Waberski, D.: Künstliche Besamung bei Haus- und Nutztieren. Stuttgart: Schattauer $\mathrm{GmbH}$.

Wallace, R. M., Pohler, K. G., Smith, M. F. \& Green, J. A. (2015). Placental PAGs: gene origins, expression patterns, and use as markers of pregnancy. Reproduction, 149(3), R115-126.

Wang, X., Wang, K., Radovich, M., Wang, Y., Wang, G., Feng, W., Sanford, J. R. \& Liu, Y. (2009). Genome-wide prediction of cis-acting RNA elements regulating tissuespecific pre-mRNA alternative splicing. BMC Genomics, 10 Suppl 1, S4.

Wathes, D. C. \& Wooding, F. B. (1980). An electron microscopic study of implantation in the cow. Am J Anat, 159(3), 285-306.

Weems, Y. S., Bridges, P. J., LeaMaster, B. R., Sasser, R. G., Vincent, D. L. \& Weems, C. W. (1999). Secretion of progesterone, estradiol-17beta, PGE, PGF2alpha, and pregnancy-specific protein B by 90 -day intact and ovariectomized pregnant ewes. Prostaglandins Other Lipid Mediat, 58(2-4), 139-148. 
Weiler, U., Claus, R., Dehnhard, M. \& Hofäcker, S. (1996). Influence of the photoperiod and a light reverse program on metabolically active hormones and food intake in domestic pigs compared with a wild boar. Can. J. Anim. Sci., 76(4), 531-539.

Weitze, K. F. (2001). Spermatologische Untersuchung. In Busch, W. \& Holzmann, A.: Veterinärmedizinische Andrologie - Physiologie und Pathologie der Fortpflanzung bei männlichen Tieren (Vol. 1, pp. 87-109). Stuttgart: Schattauer $\mathrm{GmbH}$.

Wetterstation Göttingen. (2001-2017). Extremwerte. Abgerufen am 27.08.2018, von http://www.wetterstation-goettingen.de/extremwerte.html

White, P. J., Garrott, R. A., Kirkpatrick, J. F. \& Berkeley, E. V. (1995). Diagnosing pregnancy in free-ranging elk using fecal steroid metabolites. J Wildl Dis, 31(4), 514-522.

Wiedemann, I., Maehlmeyer, A., Jansen, S., Sharifi, A. R. \& Knorr, C. (2018a). SNP g.1007A>G within the porcine DNAL4 gene affects sperm motility traits and percentage of midpiece abnormalities. Reprod Domest Anim, 53(2), 401-413.

Wiedemann, I., Krebs, T., Momberg, N., Knorr, C. \& Tetens, J. (2018b). mRNA expression profiling in cotyledons reveals significant up-regulation of the two bovine pregnancy-associated glycoprotein genes boPAG-8 and boPAG-11 in early gestation. Vet Med Sci, 4(4), 441-450.

Wolf, J. \& Smital, J. (2009). Effects in genetic evaluation for semen traits in Czech Large White and Czech Landrace boars. Czech J. Anim. Sci., 54(8), 349-358.

Wolf, J. (2009). Genetic parameters for semen traits in Al boars estimated from data on individual ejaculates. Reprod Domest Anim, 44(2), 338-344.

Wolf, J. (2010). Heritabilities and genetic correlations for litter size and semen traits in Czech Large White and Landrace pigs. J Anim Sci 88(9), 2893-2903.

Wooding, F. B. \& Wathes, D. C. (1980). Binucleate cell migration in the bovine placentome. J Reprod Fertil, 59(2), 425-430.

Wooding, F. B. (1983). Frequency and localization of binucleate cells in the placentomes of ruminants. Placenta, 4 Spec No, 527-539.

Wooding, F. B. (1984). Role of binucleate cells in fetomaternal cell fusion at implantation in the sheep. Am J Anat, 170(2), 233-250. 
Wooding, F. B., Flint, A. P., Heap, R. B., Morgan, G., Buttle, H. L. \& Young, I. R. (1986). Control of binucleate cell migration in the placenta of sheep and goats. $J$ Reprod Fertil, 76(2), 499-512.

Wooding, F. B. (1992). Current topic: the synepitheliochorial placenta of ruminants: binucleate cell fusions and hormone production. Placenta, 13(2), 101-113.

Wooding, F. B., Roberts, R. M. \& Green, J. A. (2005). Light and electron microscope immunocytochemical studies of the distribution of pregnancy associated glycoproteins (PAGs) throughout pregnancy in the cow: possible functional implications. Placenta, 26(10), 807-827.

Wooding, F. B. \& Burton, G. (2008). Synepitheliochorial Placentation: Ruminants (Ewe and Cow) Comparative Placentation: Structures, Functions and Evolution (pp. 133-168). Berlin Heidelberg: Springer-Verlag.

Wooding, F. B., Wilsher, S., Benirschke, K., Jones, C. J. \& Allen, W. R. (2015). Immunocytochemistry of the placentas of giraffe (Giraffa cameleopardalis giraffa) and okapi (Okapi johnstoni): comparison with other ruminants. Placenta, 36(1), 77-87.

Wysokinska, A., Kondracki, S., Kowalewski, D., Adamiak, A. \& Muczynska, E. (2009). Effect of seasonal factors on the ejaculate properties of crossbred Duroc $x$ Pietrain and Pietrain $x$ Duroc boars as well as purebred Duroc and Pietrain boars. Bull Vet Inst Pulawy, 53, 677-685.

Xie, S., Green, J., Bixby, J. B., Szafranska, B., DeMartini, J. C., Hecht, S. \& Roberts, R. M. (1997). The diversity and evolutionary relationships of the pregnancyassociated glycoproteins, an aspartic proteinase subfamily consisting of many trophoblast-expressed genes. Proc Natl Acad Sci U S A, 94(24), 12809-12816.

Xie, S. C., Low, B. G., Nagel, R. J., Kramer, K. K., Anthony, R. V., Zoli, A. P., Beckers, J. F. \& Roberts, R. M. (1991). Identification of the major pregnancy-specific antigens of cattle and sheep as inactive members of the aspartic proteinase family. Proc Natl Acad Sci U S A, 88(22), 10247-10251.

Xing, Y., Ren, J., Ren, D., Guo, Y., Wu, Y., Yang, G., Mao, H., Brenig, B. \& Huang, L. (2009). A whole genome scanning for quantitative trait loci on traits related to sperm quality and ejaculation in pigs. Anim Reprod Sci, 114(1-3), 210-218. 
Yubero, N., Jimenez-Marin, A., Yerle, M., Morera, L., Barbancho, M. J., Llanes, D. \& Garrido, J. J. (2003). Molecular cloning, expression pattern and chromosomal mapping of pig CD9 antigen. Cytogenet Genome Res, 101(2), 143-146.

ZDS. (2005). Gewährschaftsbestimmungen (Stand 20.10.2005) - Anforderungen an Besamungseber hinsichtlich ihrer Eignung zum Einsatz in der KB: Zentralverband der Deutschen Schweineproduktion e.V.

Zhang, Z., Zhang, Q. \& Ding, X. D. (2011). Advances in genomic selection in domestic animals. Chin Sci Bull, 56(25), 2655-2663.

Zhou, G. Q. \& Hammarstrom, S. (2001). Pregnancy-specific glycoprotein (PSG) in baboon (Papio hamadryas): family size, domain structure, and prediction of a functional region in primate PSGs. Biol Reprod, 64(1), 90-99.

Zoli, A. P., Beckers, J. F. \& Ectors, F. (1990). Isolation of an ovine pregnancy-specific protein. Theriogenology, 33(suppl. 1), 366.

Zoli, A. P., Beckers, J. F., Wouters-Ballman, P., Closset, J., Falmagne, P. \& Ectors, F. (1991). Purification and characterization of a bovine pregnancy-associated glycoprotein. Biol Reprod, 45(1), 1-10. 


\section{Danksagung}

An dieser Stelle möchte ich mich bei allen, die mich auf meinem Weg durch neun Jahre TÄl begleitet, und schlussendlich zum Gelingen dieser Arbeit beigetragen haben, ganz herzlich bedanken.

Zu allererst danke ich Herrn Prof. Dr. Jens Tetens für die Übernahme des Erstprüferamtes und das damit entgegengebrachte Vertrauen sowie die intensive Betreuung und Unterstützung bei der Anfertigung dieser Arbeit und während der letzten Monate.

Herrn Prof. Dr. Dr. Matthias Gauly und Herrn Prof. Dr. Jürgen Hummel möchte ich für die spontane Übernahme des Korreferats und des Prüfungsbeisitzes danken.

Herrn Prof. Dr. Christoph Knorr danke ich für das Vertrauen, die Förderung und die Freiheiten, die ich über die ganzen Jahre bei der Bearbeitung der Projekte haben durfte. Ich habe in dieser Zeit wahnsinnig viel gelernt und bin an den Aufgaben gewachsen. Ich glaube/denke/hoffe, dass das Endergebnis in Ihrem Sinne gewesen wäre.

Ein ganz großes Dankeschön an die AGs BRIN, FB und alle sich zugehörig fühlenden für die Hilfe und Unterstützung bei allen möglichen Belangen, sei es im Labor, bei Exkursionen oder beim Anhänger rückwärts um die Ecke schieben. Außerdem vielen Dank für das tolle Arbeitsklima auf der Etage und dafür, dass wir zu EINEM großen Team zusammengewachsen sind.

Ebenfalls danke ich der AG MolBiol, ihr habt mir das nötige Rüstzeug an die Hand gegeben (von kleinen Tipps zum Probenhandling bis zur Planung von Projekten) und meinen Weg damit ganz entscheidend geprägt. Danke für die lehrreiche und vor allem schöne Zeit.

Niklas, ich bin dir unendlich dankbar, dass du mir über drei Jahre zur Seite gestanden und mich im Labor unterstützt hast. Du warst mir eine riesengroße Hilfe, ohne die so vieles nicht so schnell umsetzbar gewesen wäre.

Julia und Tony, danke für die Probensammlung und die Fahrerei nach Wilhelmshaven. 
Meinen Labor-Ziehkindern Sophie und Tony danke ich für die tolle Bürogemeinschaft, die Unterstützung und die Nachsicht, die ihr in letzter Zeit mit mir hattet.

Reza, ich danke dir für die lange, nervenaufreibende statistische Auswertung von Kopfund Schwanzfehlern. Zwar habe ich SAS nicht verstanden, dafür aber viel über Walther von der Vogelweide und diverse Propheten gelernt.

Jule, danke für alles, was ich von dir gelernt habe, deine Unterstützung und auch für deine Kritik, mit der du mich vorangebracht hast.

Vielen Dank außerdem an Annika und Simon, die mit ihren Abschlussarbeiten eine ausgezeichnete Datengrundlage geschaffen haben, auf der das "Sperma-Projekt" aufgebaut werden konnte. Simon, außerdem vielen Dank für die Bereitstellung von Abbildungen für Vorträge etc.

Ich danke Sabrina und Reiner für die vielen Tipps und Hilfestellungen bei der Etablierung des molekularbiologischen Labors, verschiedener Methoden oder wenn es einfach mal irgendwo gehakt hat.

Claudi, ich wäre wohl nicht hier gelandet, wenn du mich nicht so für die Laborarbeit begeistert hättest. Ich danke dir für die jahrelange Förderung und Unterstützung und nicht zuletzt für die Freundschaft, die daraus entstanden ist.

Der größte Dank aber gilt meinen Eltern, meiner Schwester und Mustafa. Danke für die Liebe und den Rückhalt, die unermüdliche Unterstützung und den steten Zuspruch, wenn ich mal verzweifelt bin. Danke für einfach alles. Diese Arbeit ist euch gewidmet. 


\section{Eidesstattliche Erklärung}

1. Hiermit erkläre ich, dass diese Arbeit weder in gleicher noch in ähnlicher Form bereits anderen Prüfungsbehörden vorgelegen hat.

Weiter erkläre ich, dass ich mich an keiner anderen Hochschule um einen Doktorgrad beworben habe.

Göttingen, den

(Unterschrift)

2. Hiermit erkläre ich eidesstattlich, dass diese Dissertation selbständig und ohne unerlaubte Hilfe angefertigt wurde.

Göttingen, den

(Unterschrift) 